\title{
A globalização do mercado de periódicos científicos eletrônicos e os consórcios de bibliotecas universitárias brasileiras: desafios à democratização do conhecimento científico
}

\author{
Dissertação apresentada à \\ Escola de Comunicações e Artes da \\ Universidade de São Paulo como exigência parcial \\ para obtenção do título de \\ Mestre em Ciências da Comunicação \\ Departamento de Ciências da Informação e Documentação \\ Orientador: Prof. Dr. Waldomiro de Castro S. Vergueiro
}

ESCOLA DE COMUNICAÇÕES E ARTES

UNIVERSIDADE DE SÃO PAULO

SÃO PAULO

Junho 2002 
Banca examinadora 
Dedicatória

à esposa Patricia, sem cujo amor, companheirismo e estímulo esta dissertação não seria uma realidade $e$ novos sonhos não se descortinariam...

em memória ao pequeno Lupi 


\section{Agradecimentos}

Meus sinceros agradecimentos ao orientador Prof. Dr. Waldomiro de Castro S. Vergueiro, pela excelente orientação, fornecendo-me sempre comentários muito pertinentes, bem como um contínuo incentivo à pesquisa científica, essenciais ao desenvolvimento desse estudo;

aos Profs. Drs. Octavio lanni e Murilo Bastos da Cunha, os quais trouxeram lucidez e sabedoria com seus ensinamentos, observações, e indicações de leitura sempre muito apropriadas;

aos meus pais, irmãos e familiares, por seus ensinamentos, possibilitando-me que desde cedo se formasse uma visão crítica do mundo;

à BIREME, em especial a Abel Parker, e às bibliotecárias Carmem Veronica Abdala e Rosane Taruhn, pela compreensão e todo o suporte oferecidos na condução deste estudo;

à Maria Dulce Gaudie Ley, pelos excelentes serviços de normalização bibliográfica;

e à todos aqueles que, direta ou indiretamente, me ajudaram com suas críticas e estímulos para a condução desse estudo, e cujos nomes não fora possível citar nessas parcas linhas, meu sincero obrigado... 
Sumário

\begin{tabular}{|c|c|}
\hline Dedicatória & iii \\
\hline Agradecimentos & iv \\
\hline Sumário & $\mathrm{v}$ \\
\hline Resumo & vii \\
\hline Abstract & viii \\
\hline 1. Introdução & 01 \\
\hline 2 Hipóteses & 05 \\
\hline 3 O problema da pesquisa & 05 \\
\hline 4 Justificativas & 07 \\
\hline \multicolumn{2}{|l|}{5 Objetivos da pesquisa } \\
\hline 5.1. Objetivo geral & 11 \\
\hline 5.2. Objetivos específicos & 11 \\
\hline \multicolumn{2}{|l|}{6 Fundamentação teórica } \\
\hline 6.1. A globalização e o contexto tecno-social da sociedade da informação & 11 \\
\hline 6.1.1 A globalização eletrônica & 15 \\
\hline 6.1.2 Globalização e exclusão social & 26 \\
\hline 6.2 Algumas considerações acerca da cultura do digital & 29 \\
\hline 6.3 O mercado de publicações periódicas científicas & 34 \\
\hline 6.3.1 O agente distribuidor EBSCO & 37 \\
\hline 6.3.2 O agente distribuidor Swets Blackwell & 37 \\
\hline 6.3.3 Outras iniciativas & 39 \\
\hline 6.4 O desenvolvimento de coleções & 39 \\
\hline 6.4.1 Políticas de desenvolvimento de coleções e atividades cooperativas & 43 \\
\hline 6.4.2 Panorama de consórcios existentes na América Latina & 51 \\
\hline $\begin{array}{l}\text { 6.4.3 A ação de consórcios de bibliotecas no gerenciamento de publicações periódicas } \\
\text { científicas }\end{array}$ & 54 \\
\hline 6.4.4 Os monopólios do poder no mercado de periódicos científicos & 57 \\
\hline \multicolumn{2}{|l|}{7 Metodologia da pesquisa } \\
\hline 7.1. Aspectos conceituais & 63 \\
\hline 7.2. Técnicas de coleta de dados & 66 \\
\hline 7.3. Estudo de caso: o Consórcio de Bibliotecas ProBE (Programa Biblioteca Eletrônica) & 66 \\
\hline 7.3.1. Análise e interpretação de dados & \\
\hline 7.3.1.1 Considerações gerais & 67 \\
\hline 7.3.1.2 Descrição e interpretação dos resultados obtidos & 69 \\
\hline
\end{tabular}




\begin{tabular}{|c|c|}
\hline $\begin{array}{l}\text { Parte I : Análise e discussão de questionários respondidos pelos bibliotecários membro do } \\
\text { comitê gestor do consórcio ProBE }\end{array}$ & 70 \\
\hline $\begin{array}{l}\text { Parte II: Análise e discussão da entrevista a um membro do Comitê Coordenador do } \\
\text { consórcio ProBE }\end{array}$ & 77 \\
\hline Parte III : Análise e dicussão de questionários respondidos pelos agentes distribuidores & 82 \\
\hline 8 Considerações finais e sugestões para futuros estudos & 86 \\
\hline 9 Referências & 89 \\
\hline 10 Bibliografia complementar & 99 \\
\hline \multicolumn{2}{|l|}{ Anexos } \\
\hline 1. Termo de Instituição do Consórcio de Cooperação Institucional & 105 \\
\hline 2. Termo aditivo ao Termo de Instituição do Consórcio de Cooperação Institucional & 110 \\
\hline 3. Normas para a administração do Consórcio de Cooperação Institucional & 113 \\
\hline 4. Carta explicativa acompanhando os instrumentos de coleta de dados & 117 \\
\hline \multicolumn{2}{|l|}{ 5. Questionários enviados } \\
\hline 5.1 Modelo estruturado I: Bibliotecários membros do comitê gestor do Consórcio ProBE & 118 \\
\hline $\begin{array}{l}\text { 5.2 Modelo estruturado II: Agentes distribuidores de periódicos científicos do mercado } \\
\text { brasileiro }\end{array}$ & 121 \\
\hline $\begin{array}{l}\text { 5.3 Roteiro de entrevista pré-estruturada realizada junto a Coordenadoria Operacional e } \\
\text { Gerência do consórcio }\end{array}$ & 123 \\
\hline \multicolumn{2}{|l|}{ 6. Respostas modelo I : Bibliotecários membros do comitê gestor do Consórcio ProBE } \\
\hline 6.1 Instituição respondente 1 & 125 \\
\hline 6.2 Instituição respondente 2 & 131 \\
\hline 6.3 Instituição respondente 3 & 135 \\
\hline $\begin{array}{l}\text { 6. Respostas modelo II : Agentes distribuidores de periódicos científicos do mercado } \\
\text { brasileiro }\end{array}$ & 139 \\
\hline 7. Respostas da entrevista junto à Coordenadoria Operacional e Gerência do Consórcio & 142 \\
\hline
\end{tabular}




\section{Resumo}

Esta pesquisa buscou avaliar se as bibliotecas envolvidas em atividades de consórcio estão atuando como instrumentos sociais de democratização e ampliação do acesso à informação científica através de suas políticas de desenvolvimento de coleções. Para tanto, foi realizado um estudo de caso de consórcio de bibliotecas universitárias brasileiras para aquisição de periódicos científicos. Por meio de uma postura dialética como forma de conhecimento e como método de pensar o objeto de estudo, foi realizada uma análise do contexto sócioeconômico caracterizado pela globalização eletrônica, o processo de crescente exclusão social e a mudança no fluxo do conhecimento científico para uma cultura do digital, buscando verificar quais as relações implícitas e explícitas que afetam o desenvolvimento de coleções e ampliam uma tendência marcada pelo agravamento da infoexclusão digital no Brasil em tempos recentes. Constatou-se que a forte presença de oligopólios de poder no mercado internacional de periódicos científicos e a existência de um contexto dominado pela diminuição crescente de recursos financeiros nas bibliotecas brasileiras, sobretudo a partir da década de noventa, tem restringido a amplitude das metas de consórcios e impedido que se maximize, assim, o ganho social em longo prazo. Os resultados da pesquisa também revelaram que persistem desafios para o desenvolvimento de coleções através de atividades cooperativas, dentre eles o fortalecimento das atividades de marketing executadas pelas bibliotecas participantes, permitindo maior disseminação dos recursos eletrônicos existentes e um maior poder de negociação do consórcio com os oligopólios do mercado de periódicos científicos. Além disso, ficou constatada uma carência real pela realização de novos consórcios de bibliotecas, que contemplem outros tipos de documentos que não periódicos científicos e associados às bibliotecas públicas e regionais, possibilitando uma democratização do conhecimento para uma maior parcela da sociedade, minimizando a exclusão digital existente. 


\begin{abstract}
The research aimed at evaluating the consortia activities in terms of its performance as social instruments of democratization and broadening of scientific information access, by means of its policies of collection development. A case of study of brazilian University libraries' consortia for the acquisition of scientific journals was carried out.

By means of a dialectal point of view as a way to develop new knowledge and methodology for this research's subject matter, an analyses of the electronic globalization's social and economic context was performed, as for the growing of social exclusion, and the change in the flow of scientific knowledge towards a digital culture.

The analysis above struggles to check implicit and explicit relations affecting collection development and widening a trend, marked by the gravity of current digital exclusion in Brazil.

Research findings revealed that : the presence of scientific publishers monopoly power and the lower budgets of the brazilian libraries in the nineties, have restricted consortia's purposes as well as blocked likely long-term social gains; challenges for collection development through cooperative activities still persist among them, the strenghtening of marketing actions performed by those participating libraries, allowing greater electronic resources dissemination, as well as greater negotiation posssibilities between consortium and monopolies in the scientific periodicals market; lack of new libraries consortia embracing other types of documents - non-scientific journals - associated with public and regional libraries, allowing knowledge democratization to greater extents of society, minimizing digital exclusion.
\end{abstract}


"Na mesma medida que se transnacionalizam as forças produtivas, compreendendo as instituições, os códigos e os parâmetros que organizam as relações de produção, transnacionalizam-se os grupos e classes sociais. (...) Enquanto isso, os setores populares, ou os grupos e as classes sociais subalternos, são desafiados a se ajustarem a uma realidade econômica de âmbito social, econômica, política e cultural de âmbito mundial..."

- Octavio lanni

\section{Introdução}

O processo de transformação da economia mundial através da globalização e a conseqüente criação de uma única economia informacional engendraram uma nova arquitetura do mundo (re)dividindo-o em dois grandes blocos: uma grande maioria de nações e mercados de excluídos"; e uma pequena parte de nações ou mercados ricos - ou "incluídos", aqueles cada vez mais dependentes destes.

De uma economia pautada pela maximização da produção (acumulação de capital durante toda a era industrial) saltamos para uma economia informacional baseada num modelo de desenvolvimento tecnológico, por meio da acumulação de conhecimentos e maiores níveis de complexidade no processamento da informação.

Esse aumento de produtividade do sistema capitalista, ocorrido nas duas últimas décadas (anos 80 e 90), criou uma opinião quase unânime entre a comunidade de cientistas sociais : a evolução contínua da produtividade industrial e do crescimento econômico não é diretamente proporcional às novas descobertas científicas, liberando a mão-de-obra da produção material em benefício de atividades de processamento da informação, ou seja, voltadas para o setor de produção e disseminação da informação, o novo pilar da economia mundial.

$\mathrm{Na}$ realidade, esta nova lógica do capital foi impulsionada por diversos fatores, mas dois foram cruciais: o grande avanço trazido pelo uso de novas tecnologias, através da Internet e da explosão de novos produtos, expandindo mercados no ramo das telecomunicações e de serviços de informação; e um inquestionável aumento da produtividade nas últimas décadas, perpetuando-se um ciclo ímpar do capitalismo. Um exemplo do que ocorre no contexto brasileiro é mostrado através de diversas reportagens; dentre elas, podemos citar uma com dados bastante ilustrativos: "Dobra número de empregos no setor de telecomunicações." (publicada no Estado de São Paulo em 23/01/2001) 2.

\footnotetext{
1 Esta terminologia usada para denominar os excluídos será aqui adotada para designar as camadas mais pobres e desfavorecidas das sociedades, embora alguns pesquisadores a desaprovem, pois, para muitos, estaria carregada de um determinismo tendencioso.

2 Disponível em: <http://www.estadao.com.br/tecnologia/telecom/2001/jan/23/57.htm>. Acesso em 25/01/2001.
} 
Todas essas transformações recentes trouxeram alterações sensíveis ao contexto das universidades e ao meio educacional em todos os níveis, bem como ao processo de aquisição de publicações científicas em bibliotecas - como continuação do processo histórico que se iniciou na décadas de 60 e 70, naquela ocasião exclusivamente devido ao "boom" do crescimento exponencial da ciência e, conseqüentemente, da produção bibliográfica (SOLLA PRICE, 1974: 97).

Este processo por que passa o capitalismo não deixa de ser único e paradoxal, pois, a princípio, pode estar criando condições ou mecanismos para o surgimento de organizações nas sociedades em desenvolvimento que propiciem uma democratização do conhecimento, possibilitando então a construção de um quadro socialmente mais justo, como é o caso das ONGs - Organizações Não-Governamentais - e de outras sociedades civis. Mas, por outro lado e simultaneamente, como parte de um modelo de desenvolvimento sistêmico globalizado, ele pode elitizar o conhecimento ainda mais, num processo ad infinitum. Sob tal contexto, os periódicos eletrônicos também carregam este aspecto de dualidade: eles não mais são vistos apenas como bens de um alto valor científico e cultural, mas sobretudo como bens de um alto valor monetário, exprimível freqüentemente em orçamentos superiores a meio milhão de dólares em nossas bibliotecas.

Estima-se que se encontram disponíveis no mercado nacional (há tempos) globalizado mais de 8.000 periódicos eletrônicos pagos ou oferecidos em conjunto com sua versão impressa através de consórcios, segundo estimativa do consórcio ProBE (RELATÓRIO PROBE, 2001), colaborando assim para o agravamento das dificuldades no gerenciamento de coleções de periódicos das universidades brasileiras.

Segundo o ISSN International Center ${ }^{3}$, uma publicação seriada é definida como (...) Uma publicação, em qualquer meio, editada em sucessivas partes, comumente tendo designações numéricas ou cronológicas e intencionada por ser continuada sem uma data final pré-determinada. Nota: A definição exclui trabalhos intencionados por serem publicados em um número finito de partes ou edições. (...) O ISSN é aplicável para uma população inteira de periódicos, sejam passados, presentes ou a serem publicados em um futuro previsível. Seriados incluem periódicos, jornais, anuários (relatórios, yearbooks, diretórios, etc), revistas científicas, séries, memórias, proceedings, relatórios, etc de sociedades.

Em comparação, para se ter uma idéia mais exata do crescimento desse mercado, segundo o ISSN International Center (2001:1), temos atualmente mais de 700.000 periódicos correntes no mundo, conforme indica o quadro abaixo.

\footnotetext{
${ }^{3}$ Disponível em: <http://www.issn.org:8080/English/pub/faqs/issn>. Acesso em 23/04/2002.
} 


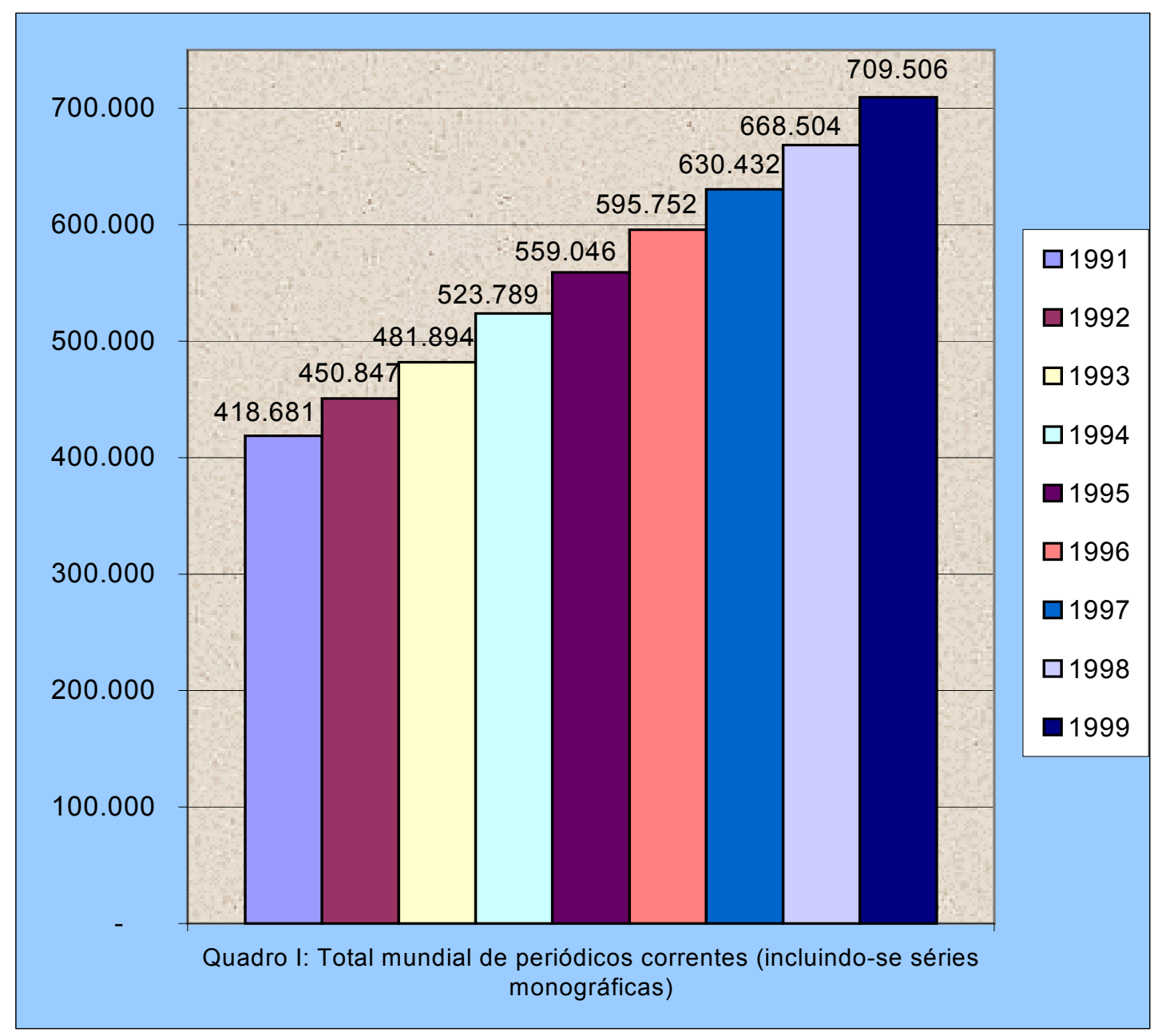

Quadro I: Total mundial de publicações seriadas correntes de 1991 a 1999.

De 418.681 títulos em 1991, houve um salto para 709.506 títulos em 1999, ou seja, um crescimento de $69,5 \%$. Assim, o quadro anterior mostra o constante e forte crescimento desse mercado nos últimos anos, ao contrário do começo do século. No caso específico brasileiro, esse número sofreu também forte expansão. Assim, de 4.321 títulos correntes em 1991, passou-se para 8.643 títulos em 1999 e, mais recentemente, 8.372 títulos correntes em 2002, o que mostra um acentuado crescimento nos últimos dez anos. Embora isso reflita o próprio crescimento da literatura científica nesta última década, com sua explosão ocorrendo sobretudo a partir de 1997, como aponta o quadro II mostrado abaixo, é oportuno salientar que a definição dada pelo ISSN International Center abrange um escopo de publicações mais largo ao estrito objeto desta pesquisa, embora não menos importante: as publicações seriadas como um todo, e não estritamente os jornais ou revistas científicas do mercado brasileiro. 


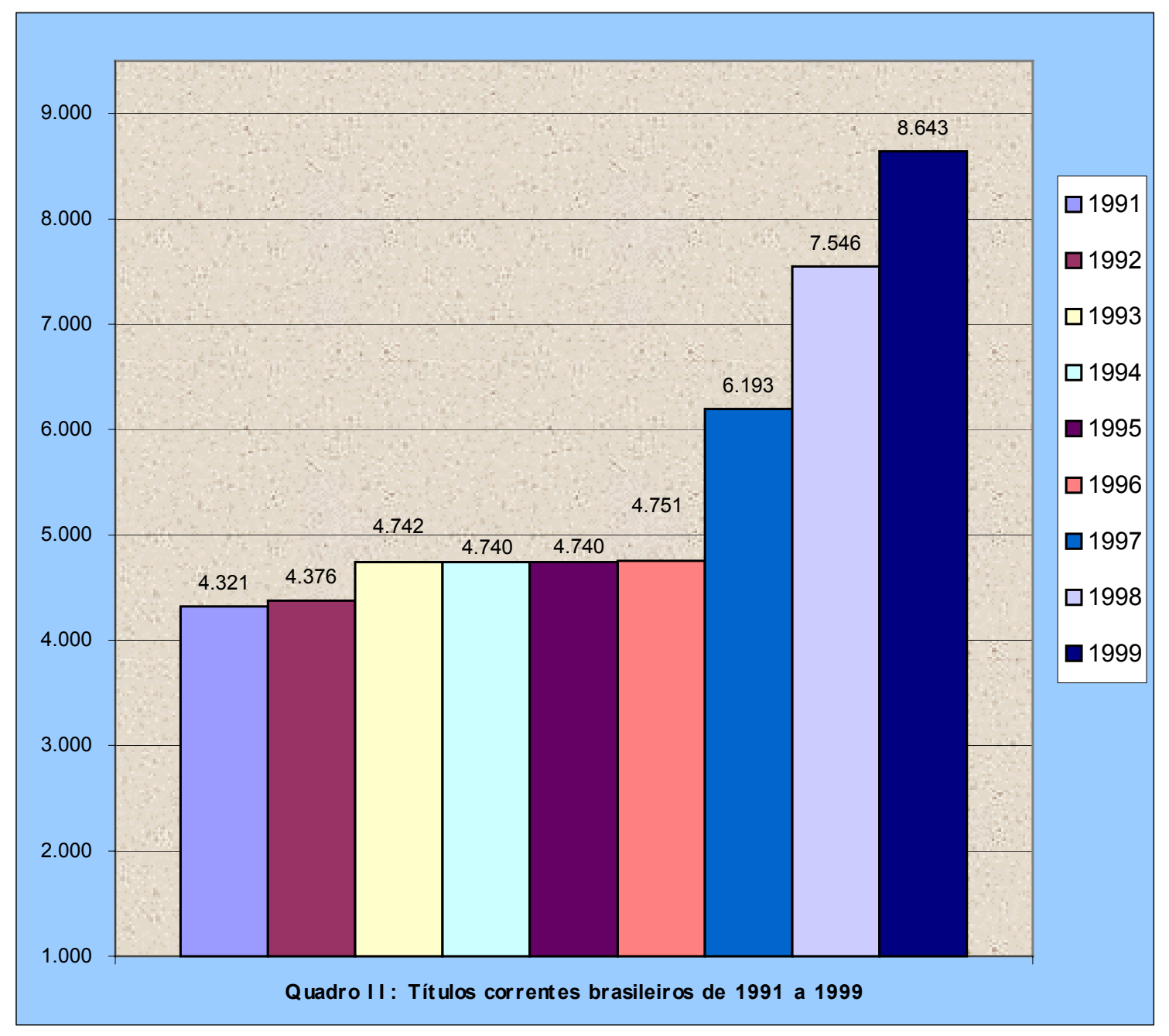

Quadro II: Total de publicações seriadas correntes publicadas no Brasil, de 1991 a 1999.

O mercado de periódicos científicos é então caracterizado pela ação de grandes empresas transnacionais atuantes num mercado globalizado, exercendo formas de oligopólios de poder, as quais podem estar alterando acentuadamente os resultados e metas esperados pelas bibliotecas universitárias brasileiras, por intermédio do gerenciamento de suas políticas de desenvolvimento de coleções. Dentre as metas principais inseridas nestas políticas (e que deveriam estar sendo cumpridas) está a democratização do acesso à informação científica gerando novos conhecimentos - e, em última instância, a promoção do bem comum por nossa sociedade.

Estas grandes empresas transnacionais podem ser caracterizadas sob dois grandes grupos: grandes editores e agentes. Um agente pode ser caracterizado como sendo um intermediário neste processo de comercialização. Segundo a definição de Andrade \& Vergueiro (1996: 41), agências ou distribuidores 
... são empresas especializadas no fornecimento de materiais de informação produzidos por um número variado de editoras, funcionando como intermediários entre estas e os compradores (...) As agências, diferentemente das editoras, que só vendem o material que publicam, e das livrarias, que em geral só mantêm em estoque as publicações mais recentes, estão aptas a conseguir uma grande quantidade de material proveniente das fontes mais diversas, independentemente da editora ou data de publicação, dentro das limitações do mercado. Como todos os demais fornecedores de material de informação, muitas agências também atuam em áreas especializadas. Existem as que só trabalham com periódicos, outras que só comercializam livros. Umas têm preferência por países ou continentes, outras especializam-se em fornecer materiais de editoras universitárias.

Os agentes distribuidores de periódicos científicos oferecem diversos títulos às bibliotecas e/ou consórcios, de um conjunto de diferentes editores ou mesmo de um único editor (casos das transnacionais Swets-Blackwell e Ebsco). O grande editor científico, tradicional, ao contrário, oferece apenas títulos dos quais ele detém o direito de "copyright" (como é o caso da Elsevier, a qual foi recentemente incorporada pela grande empresa [corporation] Thompsom Co.). Em ambos os casos há, diferentemente dos pequenos editores científicos, que resistem heroicamente em sobreviver, um serviço sofisticado, disponibilizado por meio de um desenvolvido software de busca, com interface personalizada e repleta de recursos para o pesquisador (MACHOVEC, 1997: 1).

\section{Hipóteses}

- O agravamento das dificuldades de gerenciamento das políticas de desenvolvimento de coleções de periódicos praticadas nas universidades brasileiras está relacionado ao surgimento e crescimento acelerado do mercado de publicações eletrônicas, inserido numa conjuntura sócio-econômica caracterizada sobretudo pela globalização de mercados e um processo crescente de exclusão social ;

- A atividade de consórcios de bibliotecas no gerenciamento da aquisição de revistas científicas, apresentada como uma possível solução para a ampliação do acesso à informação científica, não vem equacionando todos os desafios impostos às bibliotecas brasileiras, tais como a escassez de recursos financeiros, agravada pelas mudanças no mercado globalizado de publicações científicas, principalmente a partir da década de 90 .

\section{0 problema da pesquisa}

Uma série de tensões advindas de fatos ocorridos no mercado de periódicos científicos eletrônicos retrata uma nova realidade para as bibliotecas universitárias brasileiras e suas atividades cooperativas. Para citar apenas dois acontecimentos importantes, apontamos: 
1) a estratégia de atuação de sobretaxar continuamente os preços dos periódicos científicos de forma a aferir maiores lucros, praticada pela maioria dos grandes editores e agentes distribuidores de periódicos e fortalecida ainda mais com a globalização, sendo assim desfavorável às bibliotecas, mesmo perante aquelas atividades de desenvolvimento de coleções que visam à economia de recursos; e

2) os problemas de viabilidade técnica e política da atuação dos consórcios, os quais buscam, somados todos os prós e contras, ser efetivos instrumentos de cooperação entre unidades de serviços bibliotecários, servindo como ferramentas de democratização do conhecimento em meio ao processo crescente de infoexclusão em países em desenvolvimento.

Neste contexto, a infoexclusão é definida como sendo um tipo de situação social na qual somos incapazes de pensar, de criar e de organizar formas mais justas e dinâmicas de produção e distribuição de riqueza simbólica e material, e na qual a liberdade formal básica do universo liberal-democrático está ainda fragilizada ou inexiste. ${ }^{4} \mathrm{Na}$ infoexclusão, o cidadão não pode acessar e compreender instantaneamente o que os outros falam, sem com eles poder interagir, estando assim privados da velocidade de comunicação.

De um ponto de vista mais específico, podemos afirmar que a grande tensão político-social vivenciada pelas bibliotecas brasileiras ocorre, em parte, devido à reticente existência de políticas de desenvolvimento de coleções já arcaicas, as quais permanecem centradas num modelo concebido e direcionado às atividades (ainda vistas sob a ótica puramente técnica) de seleção ou compra de produtos de informação, reforçando tão somente uma cultura do consumismo. Essa cultura espelha-se nas práticas de valorização da posse de publicações impressas, quando as tendências econômicas (diminuição de recursos financeiros de bibliotecas), científicas (explosão do volume de produção científica produzida), tecnológicas (expansão incessante da informação eletrônica) e sociais (crescente processo de infoexclusão da sociedade) apontam para a necessidade de uma sinergia entre a posse (desenvolvimento de acervos locais) e o acesso à informação científica (através da informação hospedada em recursos remotos disponíveis nos mais diferentes pontos da Internet).

Outros problemas secundários, paralelos à esta questão central e que também devem ser analisados, são: a) a dinâmica inerente a este mercado, marcada pelo oferecimento crescente ou migração de revistas cientificas impressas para o meio eletrônico, algo que de fato é polêmico e não encerra em si a discussão sobre o assunto; b) a (des)sintonia política dos consórcios com as próprias políticas internas de cada uma das universidades que deles

\footnotetext{
4 Esta definição parte da confluência dos trabalhos dos autores AFONSO (2001); SILVEIRA (2001); e SCHWARTZ (2000).
} 
participam; e c) as implicações dos consórcios para os profissionais de informação, ao (tentarem) promover e orientar o público em geral para a aquisição de novos conhecimentos, fazendo-o como antes do surgimento dessa nova era tecnológica - se podemos assim denominar a da geração do hipertexto e da comunicação midiatizada, amplificada ao extremo - e presente, principalmente, no dia-a-dia de parte da população, considerada então como extrato social privilegiado.

\section{Justificativas}

A proposta de realização desta Dissertação originou-se de uma constatação inicial, no campo do desenvolvimento de coleções de bibliotecas, de que as teses e pesquisas desenvolvidas tendem, há anos, para trabalhos de uma linha de pesquisa funcionalista, caracterizada pelo levantamento de grande quantidade de dados. Estes trabalhos são advindos sobretudo da escola norte-americana, estancados na análise descritiva própria das teorias então vigentes - salvo honrosas exceções ${ }^{5}$.

Prova desta tendência é que, fazendo a revisão de literatura, o confronto de dados e recomendações mostrou que diversas teses e dissertações apontam para a necessidade de prosseguir com linhas de pesquisa que tenham como meta uma análise interpretativa do contexto externo relacionado ao desenvolvimento de coleções, como aponta o estudo de Klaes (1991: 204), por exemplo. Ao fazer uma análise de metodologias para a tomada de decisões para o desenvolvimento de coleções em sua dissertação, a autora cita como uma de suas recomendações :

estudar outros fatores do contexto que possam exercer influência, a médio e longo prazo, sobre o processo de desenvolvimento de coleções, como tecnologia, aspectos econômicos (inflação etc.), política científica e tecnológica, política de ensino superior, integração empresa / universidade, os quais constituem outros elementos do meio ambiente.

Assim, parte das esparsas dissertações e estudos de caso nacionais sobre o assunto, produzidos nos últimos anos, continuam a demonstrar uma grande ênfase em métodos de análise quantitativos, notando-se aí um reflexo ou forte influência do pragmatismo americano, o qual dá pouca importância a fatores ambientais, ou sócio-econômicos e comportamentais, como aqueles citados na introdução deste estudo; isso, longe de reduzir a importância de tais pesquisas na produção de um novo saber, aponta para a constituição de uma lacuna importante na área de desenvolvimento de coleções, comparando-se com boa parte das

\footnotetext{
5 No caso brasileiro, como exemplos podemos citar as teses de Waldomiro Vergueiro (1990), pelo menos em parte, a de Patricia Marchiori (1998) e a de Antonio Miranda (1987).
} 
pesquisas internacionais, que se utilizam de métodos de pesquisa qualitativa ou a combinação de ambos, com maior freqüência. (VERGUEIRO, 1990; HITCHCOCK, 1997).

Embora estas considerações sejam importantes, na ciência da informação e mesmo em campos correlatos, há outro bloco de pesquisas recentes apontando que a tendência apontada anteriormente não é uma regra geral e que existem exceções, constituindo-se em toda uma nova geração de pesquisadores que vem analisando a mudança para uma cultura do digital e o uso intensivo da Internet como focos principais abordados, embora poucas dessas pesquisas tratem da questão da democratização do acesso à informação científica e, indiretamente, ao novo conhecimento. Provas disso chegaram a todo momento enquanto se elaborava esta pesquisa, como, por exemplo, o trabalho concluído em 1997 por Gardel Amaral na Universidade de Brasília, em que o autor analisou o uso da rede no compartilhamento da informação científica nas universidades.

Não podemos esquecer, também, que a crise por que passam a sociedade brasileira e todas as sociedades envolve algo mais profundo, a instituição dos direitos de cidadania (ou ausência de). Tomemos como exemplo a problemática em estudo: a da democratização do acesso à informação científica. Boa parte da população e mesmo da comunidade de pesquisadores brasileiros permanece com carências de informação, mas não sabe ou não tem condições de suprimi-las plenamente. Mas essas carências refletem necessidades básicas e interesses que variam de indivíduo para indivíduo e são, mais do que isso, a manifestação de algo mais profundo: o direito ao conhecimento. Uma sociedade é democrática somente quando respeita "...a vontade da maioria , que é condição do próprio regime político, ou seja, quando institui direitos" (CHAUí, 1994: 431).

A propósito, usando-se uma adaptação a partir do texto de Teixeira Coelho (1997: 144-145), definem-se democracia e democratização cultural como sendo o direito de ter acesso a determinados modos culturais, recorrendo-se aos instrumentos adequados de educação, sensibilização e facilitação de práticas (programas educacionais lastreados em práticas culturais; programas de visitas guiadas a instituições culturais voltadas para crianças, jovens e adultos; subsídio aos preços de ingressos e recursos análogos), além da ampliação de uma população consumidora de bens culturais. E, mais importante até, a democratização passa por políticas de ampliação do capital cultural da população, ou seja, da criação de condições permanentes para que esta tenha a capacidade de consumo e ao mesmo tempo produção da cultura em seus mais variados vetores, permitindo-lhes inclusive uma discussão das formas de controle dessa dinâmica cultural.

No entanto, mesmo com esta definição, para estudar o que seja a democracia - no seu sentido mais amplo - é necessário uma ressalva, dado que passamos justamente por um processo de crise da democracia, onde podemos afirmar que as sociedades estão 
desprovidas de cidadãos - se considerarmos o modelo anterior de democracia, tradicional - e talvez, em última instância, vivemos um estado de uma não-sociedade. Como oportunamente coloca Guéhenno (1993), citado em Castells (1999b: 366):

nos dias de hoje, ao invés de sujeitos autônomos, há apenas situações efêmeras, que servem de base para a formação de alianças provisórias sustentadas por forças mobilizadas conforme as necessidades de um dado momento. Ao invés de um espaço político, fonte de solidariedade coletiva, existem apenas percepções predominantes, tão efêmeras quanto os interesses que as manipulam. Há, simultaneamente, uma atomização e homogeneização. Uma sociedade incessantemente fragmentada, sem memória nem solidariedade, que recupera sua unidade tão-somente pela sucessão de imagens que a mídia lhe devolve toda a semana.

Em se tratando especificamente de periódicos eletrônicos, Gardel Amaral coloca-nos uma questão relevante (1997:125) :

... estão os periódicos tradicionais em processo de migração para o meio eletrônico ou os editores apenas adotam a mídia eletrônica para efetivar suas estratégias de marketing ? Alguns autores acreditam que não há como proceder a essa suposta migração.

Responder a esta e outras questões se tornou mais que um importante desafio, mas, também, uma necessidade para todos que trabalham diretamente com a publicação científica e eletrônica. Sobre a razão desta migração já existem estudos empíricos indicando que a preferência pelos periódicos eletrônicos se dá por razões pragmáticas e culturais (manipulação facilitada do texto digital, transportabilidade, capacidade de duplicação exponencial, atração pela mídia eletrônica, etc.), e não pelo simples fato de substituir e/ou solapar o texto impresso.

Uma das mais importantes contribuições aos desafios presentes - e, igualmente, ao desenvolvimento de coleções - são os estudos da abordagem sistêmica, juntamente com os problemas suscitados por C. West Churchman em sua obra "Introdução à Teoria dos Sistemas". O alcance dos desafios ali colocados pelo autor foram bem detectados no artigo de Borges (2000). Churchman (1971:17-18) os coloca da seguinte forma :

“... suponhamos que comecemos fazendo a lista dos problemas do mundo de hoje que em princípio podem ser resolvidos pela moderna tecnologia. Em princípio, temos a capacidade tecnológica de alimentar, abrigar e vestir adequadamente todos os habitantes do mundo. (...) temos a capacidade tecnológica de oferecer suficiente educação a todos os habitantes do mundo para gozarem de uma vida intelectual madura. (...) Em princípio, temos a capacidade de organizar as sociedades do mundo atual para realizar planos bem desenvolvidos a fim de resolver os problemas da 
pobreza, saúde, educação, guerra, liberdade humana e o desenvolvimento de novos recursos. Se o ser humano tem a capacidade de fazer todas essas coisas, por que não as faz ? Haverá algum perverso traço de caráter que corre através da espécie humana e torna um ser humano indiferente à condição do outro ? Estamos essencialmente em face de um tipo de degradação moral que nos permite ignorar nosso vizinho em razão de nosso próprio interesse ? Ou existe alguma razão mais profunda e sutil pela qual, a despeito de nossa enorme capacidade tecnológica, não estamos ainda em condições de resolver os principais problemas do mundo ? Se passarmos os olhos sobre a lista dos problemas, há um aspecto deles que logo se torna evidente: esse problemas estão interligados e se sobrepõem parcialmente. São tão interligados e imbricados de fato que não é de modo algum claro por onde devemos começar."

Poderíamos supor, então, que a primeira conclusão a que chegamos para realizarmos este e qualquer estudo, é a de que a resolução desses desafios independe da capacidade tecnológica de nossa sociedade, algo tão óbvio mas que nos passa desapercebido. Embora as teses existam, estas não são explicativas, apenas prognósticas do mundo atual. Daí o esforço em estudarmos e fazermos uso da ciência em prol da sociedade através de seus próprios pensadores (vide teorias e idéias de McLUHAN, CASTELLS, LÉVY, KUHN, etc.). Todos os grandes problemas estão estritamente interligados, e uma das maiores provas foi o desenvolvimento dos processos de globalização e da mundialização da cultura, e suas respectivas incongruências.

Por fim, outra justificativa para este trabalho advém de minha atividade profissional. Sinto-me incentivado a desenvolvê-la, pois minha atuação profissional nos últimos três anos, esteve sempre atrelada a atividades de desenvolvimento de coleções, com ênfase em projetos relacionados a publicações eletrônicas em universidades. No caso, minha experiência ocorreu em duas importantes universidades públicas brasileiras - USP e UNIFESP, relativamente bem servidas de recursos em suas bibliotecas, o que só aumenta minhas preocupações com outros contextos, como o de outras instituições menos privilegiadas. Nessas atividades, surgiram indagações e uma motivação pessoal para buscar contribuir, mesmo que de forma indireta, para o processo de construção de uma maior equidade social em nosso país, através da democratização do acesso à informação científica, algo que parte dos bibliotecários acaba deixando para trás durante a carreira profissional, por outros motivos ou ambições profissionais. 


\section{Objetivos da pesquisa}

\subsection{Objetivo geral}

Analisar as relações entre a globalização de mercados e as mudanças no fluxo de transmissão e acumulação do conhecimento científico, bem como as alterações sofridas nas políticas de desenvolvimento de coleções em bibliotecas, com ênfase na análise do mercado internacional de periódicos científicos.

\subsection{Objetivos específicos}

1. Realizar um estudo de caso de um consórcio de bibliotecas universitárias brasileiras, como ferramenta para medir sua capacidade empreendedora à frente de um grupo significativo de bibliotecas, por meio de sua atuação enquanto elemento negociador com agentes distribuidores e/ou editores no mercado de periódicos científicos.

2. Apontar novos insumos às tomadas de decisão de bibliotecas universitárias brasileiras, possibilitando aperfeiçoar suas políticas de gerenciamento de coleções para periódicos científicos.

\section{Fundamentação teórica}

\subsection{A globalização e o contexto tecno-social da sociedade da informação}

Ao construir um modelo teórico que dê conta de todos os fatores envolvidos nas políticas de desenvolvimento de coleções eletrônicas, tomar-se-á como ponto de partida a constatação, reafirmada por uma série de importantes estudos da atualidade, envolvendo as mais diversas correntes políticas (liberal, socialista, entre outras) e de diferentes tendências teóricas nas mais variadas áreas da pesquisa científica (economia, sociologia, ciência da informação, administração, história), de que as instituições de nossa sociedade estão vivendo um novo contexto político, econômico, social e cultural, sobretudo aquelas que fazem uso da informação mais diretamente - e entre estas estão as bibliotecas.

Este novo contexto é marcado pelo uso massivo das redes de informação, utilizandose das novas tecnologias de comunicação (nas quais a teia mundial de informação - a Web, é a sua expressão tecno-social mais ampla), bem como de todos os avanços obtidos na década de 90 nas áreas de telecomunicações e transportes. Assim, vivemos sob um novo contexto tecno-social: a tecnologia da informação. Como afirmaram Dosi, Freeman et ali (1988), citados em Castells (1999: 77):

... A mudança contemporânea de paradigma pode ser vista como uma transferência de uma tecnologia baseada principalmente em insumos baratos de energia para uma outra que se baseia predominantemente em insumos baratos de informação derivados do 
avanço da tecnologia em microeletrônica e telecomunicações. (...) A primeira característica do novo paradigma é que a informação é uma matéria-prima: são as tecnologias para agir sobre a informação, não apenas informação para agir sobre a tecnologia, como foi o caso das revoluções tecnológicas anteriores

Entretanto, poder-se-ia questionar se, numa realidade como a brasileira, marcada pela desigualdade social gritante, a corrupção da classe política e o sucateamento de boa parte de sua economia, os efeitos sociais e econômicos das tecnologias da informação foram, de fato, percebidos e apropriados, possibilitando deste modo um retorno social a estes segmentos menos favorecidos de nossa sociedade.

E aqui aparecem diversos discursos e dados divergentes a respeito e que serão discutidos no transcorrer deste capítulo. Apenas para citar um fato, há um consenso hoje em dia de que mais de $50 \%$ da força de trabalho brasileira migrou para o mercado informal, devido ao desemprego e como reflexo direto do fechamento de diversas micro e pequenas empresas. Um excelente retrato desse triste panorama é apresentado por um estudo de Gilberto Dupas (2000: 132), em reprodução que mostra a distribuição relativa dos ocupados segundo posição no tipo de ocupação, conforme o gráfico a seguir : 


\section{Gráfico 7}

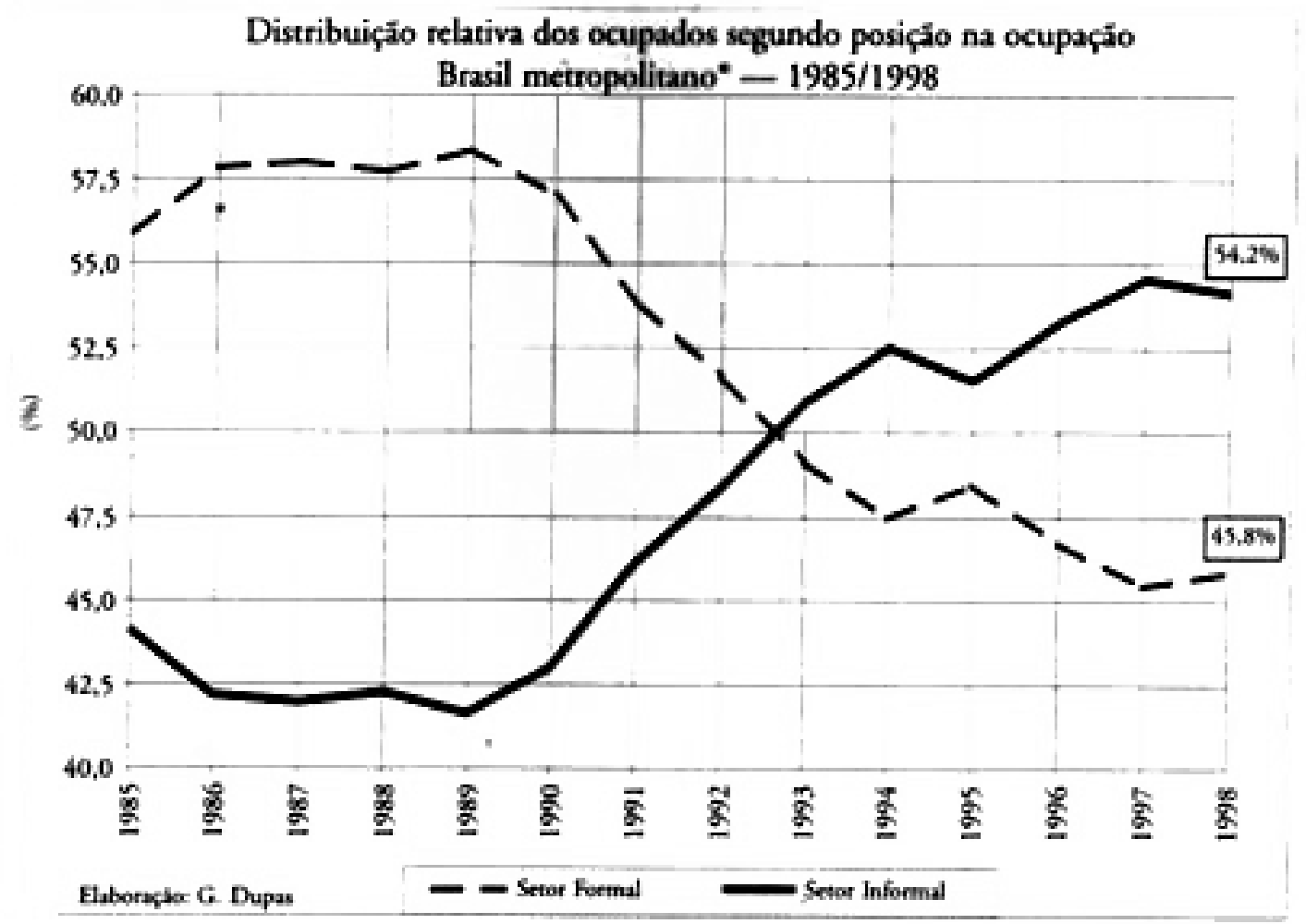

Fonte: IBGE. (") Agregaçăo das Regióes Metropolitanas: Belo Horizonte, Porto Alegre, Retife, Salvador, Rio de Janeiro e Săo Paulo.

Gráfico I: Distribuição relativa da população metropolitana brasileira, segundo tipo de ocupação (mercados formal e informal), no período 1985 a 1998. Fonte: DUPAS, Gilberto. Economia global e exclusão social. São Paulo: Paz e Terra, 2000. p. 132.

Pelo gráfico, notamos que, de 1985 a 1997, o setor informal cresceu de menos de 45\% para exatos $54,2 \%$ da população, ou seja, já é a maioria de nossa sociedade economicamente ativa, o que por si reflete um quadro de agonização de um sistema capitalista perverso.

E para a América Latina em geral, segundo a Organização Internacional do Trabalho OIT, “... o chamado setor informal já atinge cerca $40 \%$ a $70 \%$ do mercado de trabalho". (DUPAS, 2000: 58). Considerando que o uso intensivo das tecnologias de informação é tanto maior quanto maior for a capacidade dessa mesma sociedade (leia-se, forças produtivas) em assimilá-las, nossa sociedade parece caminhar, simultaneamente, para uma "descoberta" desse novo meio, assimilando cada vez mais informações, embora não necessariamente mais conhecimentos e utilizando-se das redes de informação numa cadeia crescente, embora seja incontestável que boa parte dos cidadãos ainda não tem acesso sequer a um telefone.

Reforçando essa teoria, em pesquisa conduzida pelo e-lbobe e publicada na revista Veja (NOGUEIRA \& VARGAS, 2000), foi revelado que: 
... o Brasil já possui 14 milhões de pessoas com acesso à Internet - um em cada dez brasileiros com mais de 16 anos surfaram na web pelo menos uma vez nos últimos três meses. Quando comparado com alguns países da Europa, o país (...) tem mais pessoas conectadas do que a Espanha ou a França, com pouco mais de 8 milhões cada um. (...) $\mathrm{O}$ acesso à Internet está deixando rapidamente de ser um privilégio da elite com telefone e computador em casa. Existem hoje pelo menos 6,4 milhões de internautas que só podem ser chamados assim porque desfrutam a web no trabalho, na escola, na universidade ou em outros locais, como os cibercafés.

Embora não possamos fazer generalizações a partir desses números, como afirmar que a maioria das pessoas tem acesso à Internet e podem desfrutar de todas as suas benesses, cada vez mais pessoas estão utilizando a rede para não ficarem excluídas do grande fluxo informacional que trafega em um mundo global e simultaneamente local. Mas não nos iludamos com a realidade que ora nos cerca, que é diametralmente outra, citando como parâmetros dois dados referentes à insistência de desigualdades no Brasil: em junho de 2001 foi publicada pela revista Internet Business uma pesquisa cobrindo 27 países (apud SILVEIRA, 2001:19), incluindo América do Norte, Europa, África, Ásia e América Latina, sobre o acesso à rede mundial de computadores no primeiro trimestre de 2001. Conforme aponta o autor, "... os dados confirmam a estabilidade da exclusão digital: $41 \%$ de todo o acesso mundial concentram-se nos Estados Unidos e Canadá. A Ásia, região mais populosa do planeta, detém apenas $20 \%$ dos acessos. Nossa América Latina registrou somente 4\%." ; e outra pesquisa agora mais recente do lbope, realizada de 14 a 27 de maio de 2001, onde foram colhidas 15.400 entrevistas das principais regiões metropolitanas do Brasil mais o Distrito Federal, representando uma população de 38,8 milhões de pessoas. Como cita Silveira (2001: 19-20),

nessas nove regiões desenvolvidas do país, apenas $20 \%$ dos moradores usam a web, incluindo os que afirmam utilizá-la eventualmente. Comparando com a pesquisa anterior, realizada seis meses antes, nota-se uma melhora no acesso, já que a percentagem de conectados era ainda menor: $17 \%$. Todavia, 0 crescimento aconteceu nas classes A e B - $46 \%$ dos integrantes destas classes sociais estão utilizando a Internet, ante $41 \%$ da pesquisa anterior, Entre os extratos mais pobres, o crescimentofoi bem menor: de três pontos percentuais na classe $C$ e de apenas dois pontos nas classes $D$ e $E$.

Isso prova que, no Brasil, a comunicação mediada por computador através da Internet não atinge igualmente todas as regiões e todos os extratos sociais, e, pelo que tudo indica, a expansão do acesso não será obra da expansão mercantil da Internet no país. Fica então a 
questão: quais as condições mínimas e como promover o acesso à informação científica para a população menos favorecida?

Outro aspecto dessa nova realidade está no fato que ela traz em seu bojo a globalização, a qual vem se refletindo em profundas alterações no modo de produção capitalista, e mesmo em aspectos comportamentais da sociedade, com a formação de sub-culturas e de grupos étnicos minoritários, com seus respectivos mercados específicos de consumo. Para efeitos epistemológicos, buscarei nos próximos parágrafos definir o que vem a ser a globalização, de forma a possibilitar clareza de raciocínio e rigor metodológico.

\subsubsection{A globalização eletrônica}

A globalização mostra-se como um conjunto de fenômenos complexos, envolvendo diversas variáveis. Ainda que os limites desta dissertação não possibilitem um aprofundamento do estudo da literatura específica para a compreensão total desta nova realidade que se impõe - mesmo porque, então, o foco principal da Dissertação seria outro é importante salientar que existem excelentes estudos na literatura internacional do campo. Entre essas importantes pesquisas, podemos citar, em ordem cronológica, os trabalhos de Hirst \& Thompson (1992, 1998); Cahse-Dunn (1989); Furtado (1998); lanni (1993, 2000); Mello (1999); Castells (1999); Dupas (2000).

A primeira ressalva a ser feita é o cuidado com uma vasta gama de trabalhos produzidos por bajuladores e falsos teóricos que arregimentam a favor ou contra a globalização, economizando em suas análises qualquer esforço de maior reflexão sobre o tema. Como bem expôs Octavio lanni (2000: 15), muitos sociólogos e historiadores, ao recorrerem freqüentemente ao uso de metáforas, podem dar um sinal de que há ainda uma realidade emergente fugidia das ciências sociais. Por ser um conceito relativamente novo, a globalização acaba ampliando ainda mais sua mitificação, dificultando o entendimento do fenômeno em si, bem como de todas as implicações que daí derivam. Como assinalam os autores Hirst \& Thompson (1998: 13-15) :

... é preciso acautelar-se contra as interpretações exageradas que se constróem e divulgam a partir desses fenômenos reais. Tanto mais que esses exageros e fantasias estão longe de serem politicamente inocentes. Ao contrário do que sugere o uso generalizado do termo globalização ou mundialização da economia, os mercados nacionais continuam preponderantes, sobretudo nos países maiores. (...) Os mercados de trabalho permanecem altamente segmentados por políticas restritivas de imigração e outros obstáculos à entrada de trabalhadores estrangeiros... 
Estas ressalvas dos autores reforçam a necessidade de evitar, a todo custo, uma pesquisa que acabe tendenciosa, ora pendendo demais para uma visão técno-cética, ora para uma tecno-otimista. Como em ambas podem haver pontos sustentáveis, iniciarei a partir destas uma análise comparativa, tentando estabelecer, sempre que possível, uma ponte relacionando os dois eixos e avaliações comparativas.

Inicialmente, cabe a questão: como a globalização está relacionada com o surgimento e consolidação das novas tecnologias de informação ? Esta correlação pode ser explicada por intermédio da extensa pesquisa conduzida por Manuel Castells (1999: 89) :

... uma nova economia surgiu em escala global nas duas últimas décadas. Chamo-a de informacional e global para identificar suas características fundamentais e diferenciadas e enfatizar a sua interligação. É informacional porque a produtividade e a competitividade de unidades ou agentes nessa economia (sejam empresas, regiões ou nações) dependem basicamente de sua capacidade de gerar, processar e aplicar de forma eficiente a informação baseada em conhecimentos. É global porque as principais atividades produtivas, o consumo e a circulação, assim como seus componentes (capital, trabalho, matéria-prima, administração, informação, tecnologia e mercados) estão organizados em escala global, diretamente ou mediante uma rede de conexões entre agentes econômicos. É informacional e global porque, sob novas condições históricas, a produtividade é gerada, e a concorrência é feita em uma rede global de interação. (...) A emergência de um novo paradigma tecnológico organizado em torno de novas tecnologias da informação, mais flexíveis e poderosas, possibilita que a própria informação se torne o produto do processo produtivo.

Assim, Castells e outros pesquisadores - tais como Porat (1977), Lyon (1988) e Mello (1999) - explicitam em suas teorias três fatores importantes do fenômeno: a relação direta entre o novo papel da informação e aquilo que se transfigura como o informacionalismo ou a nova fase do capitalismo mundial; o surgimento das empresas transnacionais; e a migração do comércio para uma escala global.

Com a globalização e as novas tecnologias da informação instaurou-se nas sociedades contemporâneas um ritmo de vida cada vez mais veloz, onde impera a instantaneidade da comunicação. Revela-se aí o deslocamento para um novo eixo espaçotemporal do cotidiano das diferentes sociedades. Com ele, estamos vivendo um tempo de fragilização dos laços sociais, conseqüência da aceleração das técnicas de comunicação. As cidades-mundo criadas pelo uso intensivo das técnicas de comunicação produziram então uma ressonância que ecoa na forma da solidão múltipla para milhares de indivíduos de todo o globo. Como ilustram as palavras de Paul Virilio, “... todos os homens sobre a terra terão alguma chance de se crerem mais contemporâneos que cidadãos e de evoluírem 
simultaneamente do espaço contíguo e contingente do velho Estado-nação (ou CidadeEstado) abrigando o demos, para a comunidade atópica de um Estado: o Planeta." (VIRILIO, 1996: 40).

Se a revolução tecnológica e dos meios de comunicação inaugurou uma nova percepção do espaço e do tempo do homem contemporâneo em seu cotidiano, não faltaria à humanidade inaugurar agora uma nova representação da história, mais crítica e comprometida com o mundo real e a simultaneidade de suas representações virtuais ? Não caberia à sociedade brasileira como um todo - em suas diferentes instâncias de representação política (o Estado, as sociedades civis, os partidos políticos etc) assumir a sua responsabilidade social e, fazendo uso da educação e geração de novos conhecimentos - e as bibliotecas exercem aí um importante papel - fortalecer os seus laços sociais, diminuindo as suas desigualdades sociais e redistribuir melhor a riqueza ? De que maneira esse papel é freqüentemente relegado ao Estado, que na maioria das vezes não o cumpre ? E as elites, por que persistem com uma visão assistencialista quanto ao combate à pobreza ? (REIS, 2000)

A fragilização dos laços sociais - sobretudo em países em desenvolvimento, aliada ao fortalecimento das redes de comunicação, conforma e recupera para os dias atuais uma antiga discussão: a da aldeia global. Já em idos de 1962, Marshall McLuhan preconizava que “... a nova interdependência eletrônica recria o mundo à imagem de uma aldeia global" (McLUHAN, 1977: 58). A idéia de universalização é uma questão que voltou a ser discutida na literatura, embora tenha surgido de seus estudos sobre o impacto dos mass media de então, sobretudo da televisão.

De Marshall McLuhan há as observações bem pertinentes, já na década de 70, sobre a instantaneidade dos processos e das trocas de informação e a homogeneização progressiva dos conteúdos veiculados na mídia (embora não se tenha ainda hoje dado o correto valor a estas descobertas para a evolução das teorias da sociologia da comunicação). Hoje, mais do que nunca, passamos da produção de artigos empacotados para o empacotamento de informações. Como ele bem observa, “... antigamente invadíamos os mercados estrangeiros com mercadorias. Hoje invadimos culturas inteiras com pacotes de informações, entretenimentos e idéias. Em vista da instantaneidade dos novos meios de imagem e de som, até o jornal é lento" (McLUHAN, 1974: 564-5).

Concomitantes aos estudos de McLuhan, os quais tiveram ampla divulgação pelo mundo afora, os estudos de Daniel Bell (1960) - minando as utopias ideológicas de então, ao pregar o fim destas -, bem como o trabalho do cientista político Z. Brzezinski (1969), lançaram já naquela época - fins da década de 60 e início dos anos 70 - conceitos como a cidade e a sociedade globais (Cf. MATTELART, 1999). A retomada desses conceitos nos dias atuais 
prova que a nova realidade trazida naqueles tempos pela televisão e a amplificação ao extremo do uso das redes mundiais interconectadas hoje em dia encontram entre si diversos paralelos. Os pensamentos de Brzezinski aproximam-se dos de Paul Virilio e parecem complementar-se, vistos sob o prisma atual: para este cientista político, a conotação de retorno à comunidade e à intimidade ligada à pequena cidade parece pouco adaptada ao novo meio internacional, pois as redes desta, batizada por ele de "tecnetrônica", fruto do cruzamento entre o computador, a televisão e as telecomunicações, transforma o mundo num "nó de relações interdependentes, nervosas, agitadas e tensas", portanto implicando no risco constante de isolamento e solidão do indivíduo.

Mas para os nossos dias, afirmar que o mundo pode ser visto como sinônimo de uma única aldeia global, ou de várias, é enveredar por uma linha de pesquisa que ofusca as grandes questões, do ponto de vista sociológico, econômico e político (e assim, o uso de metáforas para traduzir a realidade é uma armadilha a que vários autores sucumbem $\mathrm{e}$ poucos escapam). Como bem expôs Renato Ortiz (2000: 68-80),

... O mundo é global, mas não tem nada de aldeia. A metáfora aldeia global, criada por McLuhan, é muito ruim, na medida em que ela não tem nada de verdadeiro. Ela não dá conta de nada. Essas metáforas são interessantes, quando dão conta de determinadas questões. Mas, a partir de determinados limites, elas são muito ruins, prejudicam a compreensão da realidade. Esse tipo de mistificação é muito comum na atualidade. As pessoas começam a analisar a Internet e depois falam do mundo como se fosse a Internet. A Internet é um veículo de comunicação desenvolvido recentemente, sem dúvida muito importante, porém não é o mundo. Nem creio que a Internet seja a matriz, digamos, de uma metáfora para a compreensão do mundo. Falar que existem redes, é uma coisa, mas chegar e falar que o mundo é uma rede, é uma coisa totalmente diferente, porque o mundo não é uma rede. O problema é que as metáforas se impõem e nós acabamos sendo prisioneiros delas. Cabe a nós desarmarmos essas metáforas e vermos de que forma elas são aplicadas, em que lugares são aplicáveis e em quais não são. (...) Dentro da perspectiva atual, que é a dominante, existe uma ideologia da técnica, e, além disso, um certo encantamento. Determinados autores se encantam com a problemática da técnica atual e se esquecem de colocar esse dado novo dentro de um contexto social e histórico. Esquecem-se de que a técnica sempre foi um elemento constante da história de todas as civilizações. Existem também aqueles que acreditam na salvação pela técnica. Nem sei se existe salvação em algum lugar, porém na técnica, seguramente é que não há.

É esse encantamento da técnica e descontextualização histórica dos novos discursos que tornam discutíveis a presença de visão crítica e a própria validade de diversos textos presentes no universo acadêmico no momento presente. Qual a razão da mudança desses 
discursos, imperando a ideologia da técnica ou puramente a ausência de ideologias ? A resposta parece ser encontrada em nosso cotidiano, pelo recorte de nossa própria realidade: o contexto histórico e econômico das duas últimas décadas, caracterizado pelos fluxos torrenciais de informação e capital entre países e empresas com a descentralização dos comandos; a crise da democracia; o enfraquecimento dos direitos civis criando o 'estado de não-sociedade' e pondo-nos em troca grupos sociais e identidades fragilizadas e desprovidas das noções dos mais importantes direitos democráticos, articulados coletivamente. É sob esta ótica que se encaixa perfeitamente a observação de Pablo Casanova (2000: 46) :

Estamos num clima ideológico em que se enfraqueceram as propostas da 'soberania nacional' em favor das propostas da 'globalidade' e na qual se obscureceram os direitos dos povos diante dos direitos 'dos indivíduos'. Podemos também traçar um paralelo com o discurso das organizações civis de luta e dos movimentos sociais, que deixaram de lado o discurso da justiça social para entonar pura e simplesmente o da justiça, salvo algumas exceções. E obsoletas também tornaram-se as 'lutas de libertação' e as 'lutas de classes' para, no local, se imporem a 'inserção', a 'integração' e (...) em vez de luta social a 'solidariedade' humanitária ou empresária.

Assim, na análise dessa realidade, há de se tomar certos cuidados. Dentro da diversidade e complexidade, onipresentes na sociedade brasileira contemporânea, existem concomitantemente várias identidades, entre grupos de indivíduos com interesses e preocupações comuns, e que podem estar interconectados globalmente, porém espelhando simultaneamente sua diversidade e problemas locais. Exemplificando este fato, podemos citar o papel atual das megalópoles mundiais como pólos de atração e conexas diretamente às comunidades locais da sociedade capitalista de consumo globalizado e a consolidação de diferentes identidades sociais (étnicas, raciais, sexuais, etc.).

$\mathrm{Na}$ cultura, por sua vez, surgem fortes indícios trazendo-nos a harmonização e homogeneização progressivas para esta comunidade mundial, alavancados pelas forças da publicidade e a lógica do consumismo. Como bem observa Octavio lanni (2000: 17-18), "é nesse sentido que a aldeia global envolve a idéia de (...) shopping center global. Em todos os lugares, tudo e cada vez mais se parece com tudo o mais, à medida que a estrutura de preferências do mundo é pressionada para um ponto comum homogeneizado".

Ao não visar a produção de novos conhecimentos para a sociedade como um todo, as novas tecnologias de comunicação, propagam a ideologia dominante e os interesses de classes preocupadas apenas na manutenção de seu status quo, carregando consigo um paradoxo, bastante presente na comunidade científica, que é cada vez maior sobretudo nas revistas científicas eletrônicas, ao reproduzir o (viciado) fundamento político de Francis Bacon de que "conhecimento é poder". E sobre o poder e seus abusos, parece que há uma 
perversidade nas bibliotecas brasileiras, pelo fato delas esquecerem o que mais teriam de nobre em sua missão e contribuição social, qual seja, o ato de possibilitarem (potencialmente ou em ato) a repartição e distribuição do conhecimento, dentro de um contexto (não-) democrático. Embora os discursos apontem para o oposto, é certo que em muitas delas prepondera a obediência aos regulamentos e políticas internos em detrimento da divulgação do saber, como se suas existências se justificassem per si.

Cabe então questionar se poderíamos correlacionar numa causação simplista a cibercultura e a exclusão social. Numa primeira instância, como bem nos coloca Pierre Lévy (1999: 238), ao comentar sobre se a cibercultura seria fonte para a exclusão social,

... o problema do acesso para todos não pode ser reduzido às dimensões tecnológicas e financeiras geralmente apresentadas. Não basta estar na frente de uma tela, munido de todas as interfaces amigáveis que se possa pensar, para superar uma situação de inferioridade. É preciso antes de mais nada estar em condições de participar ativamente dos processos de inteligência coletiva que representam o principal interesse do ciberespaço. (...) Em outras palavras, na perspectiva da cibercultura, as políticas voluntaristas de luta contra as desigualdades e a exclusão devem visar o ganho em autonomia das pessoas ou grupos envolvidos. Devem, em contrapartida, evitar o surgimento de novas dependências provocadas pelo consumo de informações ou de serviços de comunicação concebidos e produzidos em uma óptica puramente comercial ou imperial e que têm como efeito, muitas vezes, desqualificar os saberes e as competências tradicionais dos grupos sociais e das regiões desfavorecidas.

Daí uma primeira inferência que podemos realizar é que a virtualidade encerra sobre si mesma uma dupla carga: positiva, onde o fluxo de informações entre o externo e o interno podem favorecer as resoluções de problemas da sociedade; e negativa, onde o direcionamento do uso da tecnologia para certos fins impulsiona somente e tão somente o consumo, replicando um estado de exclusão social e dependência.

Então, a grande questão pode ser colocada nos seguintes termos: como combater a pobreza e as formas inacabadas de formação educacional (analfabetismo, abandono à escola, falta de investimentos em educação continuada para adultos), com a contribuição das novas tecnologias ? Temos talvez uma pista, que é o fato de vivenciarmos uma sociedade que desaprendeu - ou nunca o soube de modo pleno - como participar polticamente de suas lutas pelos direitos civis e demais práticas de cidadania. E sem equacionar esses dois vetores (pobreza e sistema educacional perverso, privilegiando atualmente o ensino pago, sobretudo o fundamental), mantém-se um ciclo vicioso o que não há como se utilizar das novas tecnologias em proveito dos direitos das camadas sociais menos favorecidas de nossa sociedade. 
A resposta para o problema pode ser simples, mas a execução parece algo distante de ser realizada pelo melhor dos governos. Podemos observar que, para o pleno exercício de um estado democrático, é necessária a construção de um conjunto de fatores nos quais os indivíduos deixem de ser átomos isolados (isto é, os excluídos), que apenas utilizam a rede (se e quando o fazem) e consomem informação - para tornarem-se parte de uma sociedade comunicante que produz e comunica conhecimento (ou os incluídos), embora seja impossível traçar fronteiras nítidas entre estes dois grupos, criando-se aí um hiato tal qual uma fratura social constante, conforme é apresentado no esquema a seguir :

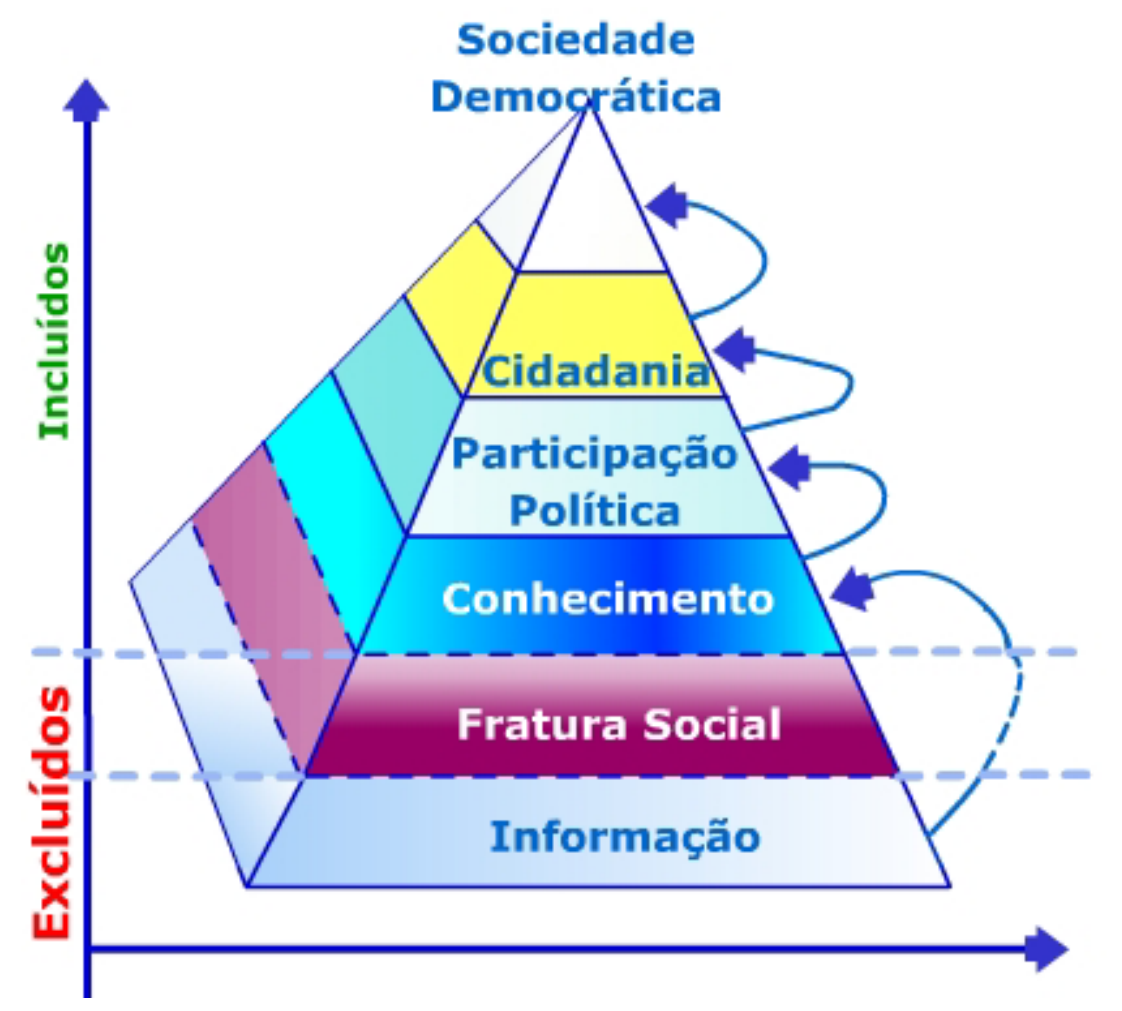

Gráfico II: Fatores existentes para a construção de um estado democrático de direito na sociedade midiática da atualidade.

No plano político, as atuações das diferentes instâncias ou formas de governo das sociedades contemporâneas estão defasadas, pois suas linhas de ação consolidaram-se numa época em que as diversas mudanças da sociedade ocorriam de forma bem mais lenta, pois a arte do motor (parafraseando o título do livro publicado por Paul Virilio) se dava numa instância inferior. Como aponta PIERRE LÉVY (1998: 61) :

... a informação é hoje torrencial ou oceânica. O hiato entre o caráter diluviano dos fluxos de mensagens e os modos tradicionais de decisão e orientação faz-se cada vez mais evidente. Os sistemas de governo ainda utilizam majoritariamente técnicas de comunicação molares. 
Retomando as questões levantadas por Lévy, qual a importância e a que propósito serviria a sua análise ? Desde que publicou suas primeiras obras, até a mais recente (Cibercultura, em 1999), o pensador Pierre Lévy, com nítida influência positivista, embora não seja um virtuoso crítico social de forma a fornecer um adequado método para atingir tal objetivo, propôs uma sociedade construída a partir de inteligências coletivas, oportuna aos nossos tempos, relacionando-a às manifestações ultra-velozes dos novos meios de comunicação. Para estas manifestações deveriam se voltar as organizações da sociedade civil e dos movimentos sociais em sua luta pela democracia e igualdade social, embora o façam ainda incipientemente através de algumas iniciativas, como os telecentros espalhados pelo país e pelo mundo afora. Nesse sentido, uma visão panorâmica destas iniciativas é propiciada pela obra de Sérgio Silveira (2001).

A maioria destas organizações não atuam eficientemente, por não saber lidar com a esfera da comunicação eletrônica (entendida aqui como a interlocução das reinvidicações e necessidades expressas por grupos sociais desfavorecidos para o uso de uma nova tecnologia avassaladora e dominante, por excelência, a qual necessitam de todo modo dominar). Mas, para não adotar um discurso demasiadamente pessimista, esperamos que a história desses grupos, pela iniciativa dos telecentros ou de políticas culturais de bibliotecas ou outros órgãos culturais (museus, etc) nos mostrem o contrário. Sem estas iniciativas, poucas são as chances vivas e pulsantes vindas do Estado para a diminuição das diferenças. Parte-se, como aponta Scherer-Warren (2001: 1-2),

... do pressuposto de que os movimentos sociais avançarão na sociedade complexa, globalizada, informatizada, na medida em que aprofundarem formas de relações sociais já emergentes - a solidariedade local e planetária ; fortalecerem-se politicamente e ampliarem sua legitimidade na sociedade civil como um todo, através de ações complementares - as redes estratégicas que conectam as ações locais com as globais ; e se avaliarem constantemente através de uma reflexividade ancorada numa relação teórico-prática, que busca entender a complexidade da sociedade contemporânea e acompanhar seu dinamismo, superando as ortodoxias teóricas e os fundamentalismos ideológicos que já não acompanham os fluxos da mudança social - contemplar a dimensão do pensamento crítico.

Assim, o que Lévy incita-nos a elaborar como resposta para esse hiato político existente parece também convergir, em termos teóricos e guardadas todas as devidas restrições, para as recomendações do estudo conduzido pela socióloga Elisa P. Reis (2000: 150-1) : seria o caso de elaborar soluções coletivas e coordenadas para combater a fome, a pobreza e os outros aspectos negativos que assolam os países em desenvolvimento ainda hoje. 
Embora o estudo de Pierre Lévy seja um tanto idealista e tido como liberal-democrata, percebe-se uma grande aproximação deste com um relatório do governo francês levado a público em idos de 1978 nos EUA por Simon Nora e Alain Minc (1981). Neste último, cunhouse, então, o termo "telemática", que traduzia a crescente interpenetração entre os computadores e as telecomunicações. Sua proposição básica expunha que

... O sistema nervoso das organizações e da sociedade como um todo deveria recriar uma ágora informacional, ampliada para as dimensões da nação moderna e deixar desabrochar a abundância da sociedade civil.

Comparando-a com o capítulo sobre política e luta pela democracia na obra de Lévy (escrito quase três décadas depois), fica patente a semelhança entre ambos. Os dois estudos levam-nos para uma mesma linha de pensamento e ação social e política, embora Lévy tenha tido condições ambientais para extrapolar em muito as questões abordadas e propor algumas soluções. Merece ser também citado nessa linha, com uma proposição bastante diferente e mais pragmática, o trabalho de Clift (2001) sobre a construção de uma democracia online, embora este termo carregue consigo uma significação de virtualidade que alguns estudiosos a questionem quanto a sua validade de fato - como o estudo de Cristiane Neder (2001) - e eu aí me incluo.

Mas a análise da globalização não se deve limitar apenas aos fatores sobremaneira políticos descritos anteriormente. Um olhar mais atento dá conta de que, na economia, temos, como um dos núcleos de análise, o que se denomina como empresa transnacional. Nesse contexto, ela sugere uma transformação quantitativa e qualitativa do capitalismo além de todas as fronteiras, eliminando ou absorvendo outras formas de organização social e técnica do trabalho, da produção e da reprodução do capital. Entretanto, isso não implica em que as empresas e indústrias de manufaturas nacionais estejam virtualmente extintas, mas, sim, que elas passam, cada vez mais, a ser incorporadas a outras organizações maiores e sobretudo de caráter mundial. Assim, como expõe Octavio lanni (2000:18), surge uma nova divisão internacional do trabalho e das forças produtivas, e a reprodução ampliada do capital desenvolve-se em escala mundial - e não apenas internacional ou multinacional.

Como coloca Renato Ortiz, se entendermos por globalização da tecnologia e da economia a internacionalização das trocas, de produtos e de conhecimento, evidentemente não estamos diante de um fato original. Para ele, o mesmo pode ser dito a respeito da multinacionalização de empresas nacionais operando em uma escala internacional. Daí a necessidade de distinção, oferecida pelos economistas, entre o que é internacionalização e globalização. Conforme aponta Dicken (1992), citado em Ortiz (1994: 15 e ss.) : 
... embora sejam usados muitas vezes como sendo intercambiáveis, esses termos não são sinônimos. Internacionalização se refere simplesmente ao aumento da extensão geográfica das atividades econômicas através das fronteiras nacionais; isto não é um fenômeno novo. A globalização da atividade econômica é qualitativamente diferente. Ela é uma força mais avançada, e complexa, da internacionalização, implicando um certo grau de integração funcional entre as atividades econômicas dispersas.

Além disso, as novas tecnologias permitem que o capital seja transportado de um lado para outro entre as economias, em curtíssimo prazo, de forma que o capital e, portanto, poupança e investimentos, estão interconectados em todo o globo, de bancos a fundos de pensão, bolsas de valores e câmbio. Uma vez que as moedas são interdependentes, as economias de todas as partes também o são (CASTELLS, 1999: 111). A empresa transnacional incita a criação de novos produtos internacionais, e o jornal, por exemplo, mais do que nunca, deixou de ser somente local para ser global e todos os acontecimentos exteriores refletem nos nossos dias na economia, política e sociedade locais de maneira vertiginosamente mais rápida e incisiva. Se as políticas dos governantes estão despreparadas para esta nova realidade, o que dizer de uma economia calcada em movimentos globais ?

Parece haver a comprovação da tendência pela formação de economias-mundo, como há tempos defendem os já clássicos estudos de Fernand Braudel (1986) e de Immanuel Wallerstein $(1979 ; 1988)$. Um retrato desses novos tempos, onde pode ser tomado como espelho um noticiário publicado em 2001 (e encontrado em outros trabalhos da literatura internacional, em que se comenta sobre uma provável unificação entre dois países - Estados Unidos e o Canadá -, outrora altamente concorrentes (PEARLSTEIN, 2000: A14):

... muitos representantes da sociedade civil influentes e com grande destaque na economia de ambos os países vêm quase como certa tal unificação, nos próximos vinte anos. (...) em uma pesquisa realizada, $80 \%$ dos canadenses que falam o inglês já consomem os mesmos bens que os americanos, além de terem as mesmas preferências culturais e de consumo. ${ }^{6}$

Como bem apontou lanni (2000: 34), embora o pensamento converja para um ponto em comum, há divergências entre Braudel e Wallerstein em vários aspectos, tanto no que se refere ao universo empírico como no relativo ao enfoque teórico. Braudel propõe uma espécie de teoria geral geo-histórica, contemplando as mais diversas configurações de economias-mundo, ao passo que Wallerstein debruça-se sobre o capitalismo moderno, embasado em recursos metodológicos muitas vezes semelhantes aos do estruturalismo marxista. O primeiro, ao contrário, está influenciado pelo funcionalismo originário de Durkheim

\footnotetext{
${ }^{6}$ Matéria originalmente publicada no The Washington Post em 14/04/2001.
} 
e desenvolvido por Simiand e outros, combinando história, sociologia, geografia, antropologia e outras disciplinas.

Então, num processo histórico, Manuel Castells deu de certa forma prosseguimento a esses estudo ao afirmar que a "nova" estrutura da economia pode ser caracterizada pela combinação de uma geometria variável e uma geometria permanente. Essa flexibilização proporcionada pela inconstância e instabilidade das realidades de cada país e sua sociedade torna qualquer projeção um sinônimo de especulação. No instante em que é escrito este texto, parecem haver três principais pólos econômicos mundiais, sob os quais gira também toda a divisão internacional do trabalho : a América do Norte, a Comunidade Econômica Européia, e a região do Pacífico Asiático, que outrora foi apenas uma economia emergente, passa por um grande surto de desenvolvimento através de conexões econômicas progressivas entre o Japão e os "quatro tigres" asiáticos, com a China e a região do Sudeste asiático. Há também um fortalecimento dos laços comerciais do Japão com a economia estadunidense e mesmo mundial, pois seus produtos e indústrias se espalham cada vez mais.

Mas há ainda uma grande assimetria na economia global quando comparamos as economias desses três pólos com as nações emergentes. À luz de uma nova análise sobre essa realidade, Castells (1999: 125-26) nos revela uma série de considerações importantes a serem pensadas:

... um grupo de países que corresponde mais ou menos aos membros da OCDE concentra uma proporção esmagadora de capacidade tecnológica, capital e mercados e produção industrial. Acrescentando-se à OCDE os quatro países recém-industrializados da Ásia, em 1988 as três regiões econômicas representavam $72,8 \%$ da produção industrial mundial, e no ano 2000 sua participação deverá totalizar $69,5 \%$, embora a população dessas três regiões no ano 2000 esteja projetada para apenas 15,7\% da população mundial. A concentração de recursos é ainda maior no centro do sistema, nos países do G-7, especialmente em termos de tecnologia, qualificações e infraestrutura informacional, principais determinantes da competitividade. Em 1990, os países do G-7 eram responsáveis por 90,5\% da indústria mundial de alta tecnologia e detinham $80,4 \%$ do poder global no setor de computação. (...) Quanto a gastos com P\&D, enquanto a América do Norte representava 42,8\% do total mundial em 1990, a América Latina e a África juntas eram responsáveis por menos de $1 \%$ do mesmo total. Dessa forma, o novo paradigma competitivo baseado em capacidade tecnológica, embora promova a interdependência da nova economia global, também reforça a dependência em uma relação assimétrica que, no geral, fortaleceu os padrões de dominação criados por formas anteriores de dependência ao longo da história.

Entretanto, não podemos afirmar que toda a força de trabalho mundial está interconectada com a economia global. Pelo contrário, como expressão de uma geometria assimétrica, temos 
segmentos de países, regiões, setores econômicos e sociedades locais desconectados dos processos de acumulação e consumo que caracterizam a economia informacional ou global. Um bom exemplo desses setores é a economia informal presente em muitos países, como os da América Latina - e bem visível aos nossos olhos. Desse modo, embora a economia informacional afete o mundo todo, e, nesse sentido, seja global, a maior parte das pessoas do planeta não trabalha para a economia informacional ou global, nem compra seus produtos. A exposição do fotógrafo Sebastião Salgado $^{7}$ é o retrato fiel dessa realidade vivenciada no Brasil e em outros países em desenvolvimento, que escancara a todos os segmentos da sociedade uma camada de atores sociais marginalizados, cujo cotidiano é pautado pelo trabalho desumano, que chega à beira de uma escravidão em pleno século vinte. Como bem observa Milton Santos (1998: 141-2),

... isso tudo se dá através de um modelo econômico, que privilegia o que se poderia chamar de distorção da produção, uma produção orientada para fora, ou external oriented, uma distorção igualmente do consumo com maior atenção ao chamado consumo conspícuo, que serve a menos de um terço da população, em lugar do consumo das coisas essenciais, de que o grosso da população é carente. Há uma relação íntima de causa e efeito entre a distorção da produção e a distorção do consumo, o que está ligado às múltiplas formas de "abertura" da economia nacional e tem um efeito sobre as outras dimensões da economia, que são também geográficas, como a circulação e a distribuição. Isso tudo com relação a uma população que cresce (...) a cada ano, o Brasil tem 3.000.000 de novos habitantes. Essa é uma dimensão fundamental para entender a existência de um Brasil rico ao lado de um Brasil pobre, e as formas atuais de reorganização do espaço brasileiro.

Esse lado perverso da economia global compõe-se por um novo paradigma do trabalho, onde o emprego é mais precário, desprovido da estabilidade associada ao padrão convencional, e mais flexível. (cf. DUPAS, 2000: 17)

\subsubsection{Globalização e exclusão social}

De um novo paradigma do trabalho chegamos às formas de exclusão social existentes. Para tratarmos de exclusão social, que é outro elemento importante e complexo a ser considerado, é necessário definir com precisão aquilo que se entende por pobreza e exclusão social, pois estes conceitos estão saturados de significados e não-significados, ou seja, podem traduzir muitas falas e anseios como, ao mesmo tempo, são repetidos por pretensos estudiosos sem

\footnotetext{
${ }^{7}$ Disponível em: <http://www.terra.com.br/sebastiaosalgado/>. Acesso em 02/02/2001.
} 
nenhum significado ou importância. No estudo de Gilberto Dupas (2000: 17 ; nota p. 35) encontramos uma vasta pesquisa que aborda a exclusão social e define sua problemática:

... A sociedade contemporânea depara-se com um sério problema, ao centrar no consumo diferenciado boa parte da realização pessoal e social. Tal possibilidade de consumo transformou-se no principal sinal exterior de sucesso individual, o que faz com que o sentimento de exclusão possa ter um teor puramente relativo, ou seja, o de estar excluído não de necessidades consideradas básicas, mas daquilo que outras pessoas têm. Essa sensação pode, com efeito, ocorrer em qualquer faixa de renda. (...) Tamanha é a sede por diferenciação que alguns bens são consumidos justamente por serem caros, o que impede o seu acesso às massas e realimenta a diferenciação. Ou seja, são bens que têm por fundamento a idéia de exclusão.

Este aspecto frisado só reforça a idéia de que a globalização retroalimenta a exclusão social, ao provocar um aumento do desemprego causado pelo enxugamento das empresas com a compra destas pelas corporações transnacionais, e, indiretamente, ao reforçar na sociedade o hábito do consumo desnecessário como necessidade de satisfação do cidadão comum, cujas mercadorias por ele adquiridas muitas vezes são padronizadas globalmente e fogem dos seus interesses sem ele se aperceber.

Tomando como essência da exclusão social a sua dimensão multidimensional, dentre os estudos pesquisados, é bem apropriada a definição apresentada por Rodgers (1995), na obra de Dupas (2000: 20):

... há vários níveis nos quais se pode estar excluído: a) exclusão do mercado de trabalho (desemprego de longo prazo); b) exclusão do trabalho regular (parcial e precário); $\quad$ c) exclusão do acesso a moradias decentes e serviços comunitários; d) exclusão do acesso a bens e serviços (inclusive públicos); e) exclusão dentro do mercado de trabalho (para ele, existe uma 'dualização do processo de trabalho', ou seja, há empregos ruins, de acesso relativamente fácil - que além de precários não geram renda suficiente para garantir um padrão de vida mínimo - e há empregos bons, mas de difícil acesso, que geram níveis de renda e de segurança aceitáveis; em geral, a segmentação acontece em termos de raça, sexo, nacionalidade); f) exclusão da possibilidade de garantir a sobrevivência; g) exclusão do acesso à terra; h) exclusão em relação à segurança, em três dimensões: insegurança física, insegurança em relação à sobrevivência (o risco de perder a possibilidade de garanti-la) e insegurança em relação à proteção contra contingências; i) exclusão dos direitos humanos.

Mas as questões relacionadas ao desemprego vão mais além e afetam não somente a sociedade brasileira, mas outras sociedades, e outras reflexões merecem ser vistas com muita atenção. O autor Adam Schaff, em sua obra "A sociedade informática" já diagnosticava 
muito bem a situação e fazia uma excelente leitura dos problemas, os quais ainda permanecem atuais. Para ele, o problema maior da nossa sociedade (SCHAFF, 1991: 27-29),

... é como assegurar a manutenção de um exército de pessoas estruturalmente desempregadas, que perderam seus empregos em conseqüência da automação e da robotização da produção e dos serviços. O mais importante fato é que há o desemprego estrutural, e não aquele ocasionado tão somente por uma conjuntura desfavorável, isto é, pela substituição do trabalho tradicional pelos autômatos, problema o qual não pode ser resolvido apenas pelo auxílio desemprego.

Para o autor, não existem muitas saídas para o problema ser enfrentado por uma única frente. Entretanto, ele sugere que, nessa situação, uma delas seria “... substituir o trabalho tradicional, no sentido do trabalho remunerado, por ocupações não remuneradas (...) ou com a redução de horas de trabalho, para que todos tenham empregos (ou pelo menos boa parte), aproximando esse número assintoticamente do ponto zero para as massas desempregadas". (SCHAFF, 1991: 33)

Alguns dados de países emergentes são também um outro sinal de alerta ao problema, como divulga um relatório sobre o desenvolvimento humano no Brasil (INSTITUTO DE PESQUISA ECONÔMICA APLICADA, 1996), o qual revela um quadro desfavorável no período 1990-1995, período este relacionado aos primeiros resultados do processo de globalização e ao aumento das preocupações com o futuro das sociedades dos países em desenvolvimento. Segundo esse relatório, o nível de pobreza aumentou no mundo. Antes, concentrava-se na América Latina, no sul da Ásia e na África. Hoje, sabemos que os países da Europa Oriental e os da antiga União Soviética engrossam a lista dos excluídos.

Se essa tendência for concretizada para os próximos anos, as gerações futuras estarão (con)formando-se com a homogeneização de idéias e defrontando-se com a exclusão social como situação comum num ritmo vertiginoso, suprimindo-se à população desprivilegiada sua noção crítica de realidade e as possibilidades de exercício de cidadania e, por conseguinte, suas esperanças de transformação - e de todos nós, agentes sociais - desta mesma sociedade. Se questionarmos se a força de trabalho produtiva dos países emergentes está presente nos mecanismos de inclusão existentes em uma sociedade informacional, fica claro que muitas dessas características não estão presentes nas sociedades latinoamericanas. O montante de recursos aplicados nesses países em pesquisa de ponta e outras áreas essenciais - como educação, saúde e reforma agrária, apenas para citar algumas delas - continua longe do ideal. Forma-se assim uma sociedade marcada pela exclusão, e contendo, ao invés de uma massa de trabalhadores ativos na rede (usada aqui em sentido restrito e abstrato), dois blocos bem definidos, sendo o segundo mais numeroso: a) trabalhadores passivos na rede, que estão on-line, mas não decidem quando, como, porque 
ou com quem; b) trabalhadores desconectados, presos a suas tarefas específicas, definidas por instruções unilaterais não-interativas. Se, a grosso modo, buscássemos elaborar o perfil do trabalhador latino-americano, teríamos, em sua esmagadora maioria, uma legião de executores, que apenas implantam as decisões de outrem...

\subsection{Algumas considerações acerca da cultura do digital}

Inicialmente, o primeiro fator a ser considerado numa cultura do digital é seu principal objeto: a informação. Esta tornou-se algo quase único no início desse novo século e é parte importante do capitalismo globalizado e a razão pela qual Castells Ihe dedica um capítulo à parte em sua obra: o seu valor intrínseco. Entre as caraterísticas especiais da informação, ainda mais quando no contexto de uma realidade pautada pela cibercultura, é importante ressaltar, conforme defende R. O. Mason (1987: 64), que :

... a) a informação não é escassa nem finita com o passar dos anos, como as matérias brutas da natureza (petróleo, gás natural, ouro etc.). Ao contrário, a modernidade e o uso das redes só agravou um outro problema derivado dessa característica, a abundância da informação disponível; b) a informação tem como características adicionais a transportabilidade; intangibilidade; é comprimível, expansível, estocável de várias formas e em vários formatos e é manipulável; c) a informação é heterogênea (...) também em seu valor. Duas pessoas na mesma organização executando função similar podem e dão à mesma informação um valor diferente. Ainda, o valor dessa informação pode mudar com o passar do tempo para uma pessoa. Em essência, o valor é subjetivo, tornando quase impossível para economistas neoclássicos desenvolveremIhe um modelo; d) a informação é indivisível no sentido de que é difícil determinar quando esta é completa. A informação incompleta ou insuficiente pode causar problemas, mas quando dizemos que esta é completa ? Em dadas circunstâncias, a informação "X" pode estar completa, em outra, entretanto, "X" será incompleta ou insuficiente.

Decorrente de todos esses aspectos, não apenas a leitura e a pesquisa bibliográfica advindas da hipertextualidade de textos acadêmicos se alteraram drasticamente, porém e sobretudo a comunicação digital entre os atores sociais envolvidos alterou-se: de um dispositivo um para um mudou para um dispositivo muitos para muitos, tendo como maior expoente o correio eletrônico. E esse fato refletiu na velocidade da comunicação entre os pares e da produção da ciência em si. Desta forma, a mesclagem de tantas propriedades advindas do virtual e do hipertexto levam os autores a significar com freqüência a biblioteca digital com muita alternância na literatura, segundo Harter (1997: 1).

A biblioteca digital, embora seja uma realidade relativamente recente, pode ser considerada um processo de evolução gradual da biblioteca tradicional acompanhando os 
avanços das novas tecnologias, conforme ressalta Cunha (2000:16), que conceitua as bibliotecas digitais de uma maneira simples porém bem adequada, como sendo “... um conjunto de mecanismos eletrônicos que facilitam a localização da demanda informacional, interligando recursos e usuários." A biblioteca digital recebe ainda diversas outras denominações, sendo conhecida também como biblioteca eletrônica (Reino Unido), biblioteca virtual, biblioteca sem paredes ou biblioteca cibernética; para efeitos desse estudo, no entanto, será utilizado tão somente o termo biblioteca digital.

As bibliotecas digitais parecem caminhar no sentido de terem uma coleção diversificada, com sua faceta digital tendo uma caracterização específica (estrutura, serviços disponíveis), movendo-se cada vez mais de acordo com os interesses e preferências de seus usuários.

Um conjunto de fatores arrolados - tecnológicos, sociais, econômicos, comunicacionais - apontam para uma realidade vista em dois momentos históricos claramente distintos, podendo ser caracterizados conforme expõe o Quadro III a seguir : 


\section{Quadro III - Evolução do Processo de Aquisição do Conhecimento}

\begin{tabular}{|c|c|c|}
\hline \multicolumn{3}{|c|}{ Cenários } \\
\hline $\begin{array}{l}\text { Natureza do } \\
\text { Fator }\end{array}$ & $\begin{array}{l}\text { Anos } 80 \text { até primeira metade } \\
\text { da década de } 90 \\
\text { (Bibliotecas tradicionais) }\end{array}$ & $\begin{array}{l}\text { Segunda metade da década de } 90 \\
\text { até os dias atuais } \\
\text { (Bibliotecas Digitais) }\end{array}$ \\
\hline Social & $\begin{array}{l}\text { Relativa distribuição de renda e explosão do } \\
\text { consumo; Crescimento do emprego, sobretudo } \\
\text { nos países membros do G-8 }\end{array}$ & $\begin{array}{c}\text { Diminuição do consumo e degradação } \\
\text { das condições de vida nas cidades; } \\
\text { Desemprego; Infoexclusão }\end{array}$ \\
\hline Econômico & $\begin{array}{l}\text { Economias ainda locais, dominadas por } \\
\text { impérios regionais e centrais (sobretudo dos } \\
\text { Estados Unidos e Japão); produção "just in } \\
\text { case” }\end{array}$ & $\begin{array}{l}\text { Economia e empresas globalizadas, } \\
\text { fortalecimento de alianças comerciais } \\
\text { regionais e de indústrias de países em } \\
\text { desenvolvimento; produção "just in } \\
\text { time" }\end{array}$ \\
\hline Tecnológico & $\begin{array}{l}\text { Surgimento e expansão de novas tecnologias e } \\
\text { sistemas em rede }\end{array}$ & $\begin{array}{l}\text { Consolidação da Internet e ambientes } \\
\text { corporativos; alto tráfego de dados } \\
\text { ("broadcasting", ênfase em conteúdos) }\end{array}$ \\
\hline $\begin{array}{l}\text { Comunicação } \\
\text { Científica }\end{array}$ & $\begin{array}{l}\text { Comunicação científica preponderantemente } \\
\text { ainda impressa, início dos projetos de } \\
\text { divulgação ultra-veloz de trabalhos científicos; } \\
\text { comunicação unidirecionada (um para um) }\end{array}$ & $\begin{array}{l}\text { Publicações eletrônicas veiculadas } \\
\text { e/ou comercializadas através da Rede, } \\
\text { diminuição de tempo no processo de } \\
\text { transmissão do conhecimento; } \\
\text { comunicação multidirecionada (muitos } \\
\text { para muitos); hipertextualidade }\end{array}$ \\
\hline $\begin{array}{l}\text { Serviços de } \\
\text { Bibliotecas }\end{array}$ & $\begin{array}{c}\text { Projetos locais de aquisição centralizada; } \\
\text { diminuição de orçamentos; aumento de custos; } \\
\text { investimentos em serviços de empréstimo inter- } \\
\text { bibliotecas; baixo incentivo ao treinamento de } \\
\text { funcionários }\end{array}$ & $\begin{array}{l}\text { Fortalecimento de consórcios regionais, } \\
\text { visando o acesso cooperativo de } \\
\text { documentos eletrônicos; intensificação } \\
\text { empréstimos inter-bibliotecas como } \\
\text { nova fonte de renda; fortes } \\
\text { investimentos em pessoal, incluindo } \\
\text { cursos a distância e ensino de línguas }\end{array}$ \\
\hline
\end{tabular}

Quadro III: Cenários elaborados a partir do estudo original de Evans (1995).

Neste cenário, é obrigatório salientar certas características que diferenciam um documento digital de um impresso. A primeira delas, e talvez a mais importante, é sua característica mais inovadora: a hipertextualidade. O autor que primeiro a definiu foi Vannevar Bush (1945) - e é desse modo conhecido por todos como o "pai do hipertexto", - em seu trabalho How we may think. Foi considerado, entretanto, mais oportuno - considerando-se o contexto das 
bibliotecas digitais -, o raciocínio de Pierre Lévy (1999: 254), pelo qual certas características são determinantes para a definição do hipertexto: “... uma forma não linear de apresentar e consultar informações. Um hipertexto vincula as informações contidas em seus documentos (ou 'hiperdocumentos', como preferem alguns) criando uma rede de associações complexas através de hyperlinks ou, mais simplemente, links". Estas características remetem o hipertexto a um período anterior ao digital, servindo-Ihe de inspiração em sua forma mais primitiva: a ligação entre os volumes mantida pelas remissões, notas de pé de página, as citações e bibliografias, tanto quanto os fichários e catálogos de bibliotecas constituindo-se em uma rede de documentação mantida pelas mesmas. O suporte digital trouxe assim uma mudança considerável. Com o hipertexto, o uso de instrumentos de orientação, a passagem de um nó a outro são feitos, no computador, com grande rapidez, da ordem de segundos. Mas não apenas isso a hipertextualidade trouxe como inovação. Nas palavras de Lévy (1999: 57),

... a tendência contemporânea à hipertextualização dos documentos pode ser definida como uma tendência à indeterminação, à mistura de funções de leitura e de escrita. (...) Se definirmos um hipertexto como um espaço de percurso para leituras possíveis, um texto aparece como uma leitura particular de um hipertexto. O navegador participa, portanto, da redação do texto que se lê. Tudo se dá como se o autor de um hipertexto constituísse uma matriz de textos potenciais, o papel dos navegantes sendo o de realizar alguns desses textos colocando em jogo, cada qual à sua maneira, a combinatória entre os nós. O hipertexto opera a virtualização do texto.

$\mathrm{Na}$ tentativa de uma diferenciação entre o documento impresso e o digital, começa a firmar-se o termo "tradicional" para designar tudo aquilo que é tido como "não-digital", conforme salientam autores importantes da área, como Ewing (1995), Fecko (1991) e, sobretudo, Atkinson (1997). Em um trabalho deste último, encontramos uma excelente esquematização dos formatos existentes, transcrita a seguir na figura 1: 


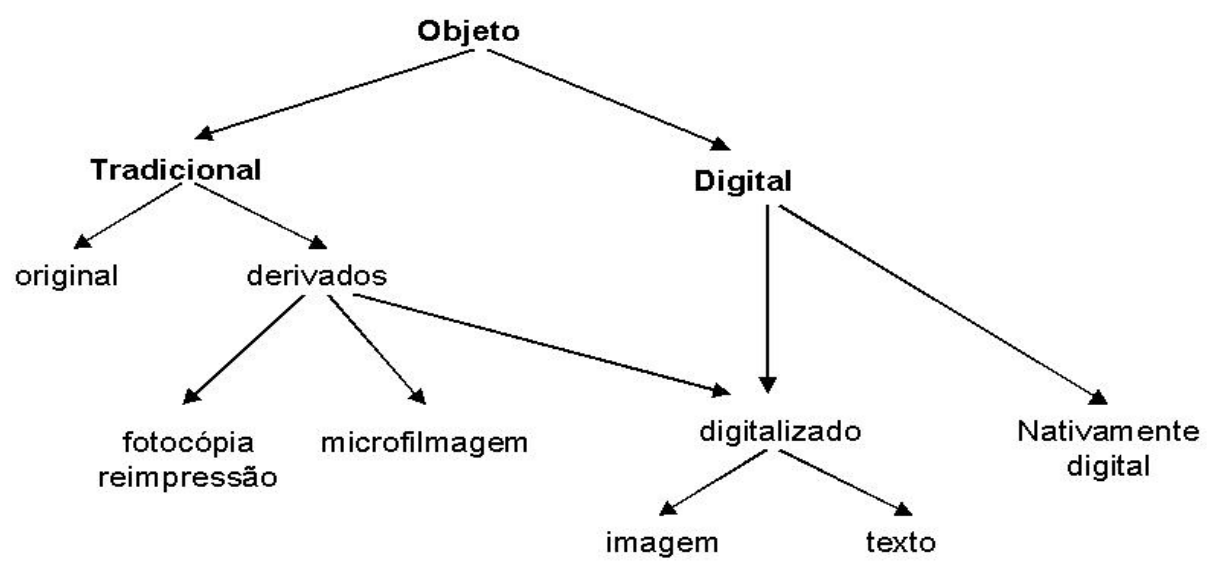

Figura 1: Relacionamentos entre objetos de informação, adaptado do estudo feito por Atkinson (1997: 9).

O autor mostra que, tanto do tradicional como do digital, surgiram formatos derivados, embora entre estes não exista a mesma propriedade quanto ao que carregam. Nas palavras de Atkinson (1997:9),

... enquanto existem claramente derivados dos objetos digitais, não ocorre o mesmo com os derivados de objetos tidos como tradicionais. Derivativos digitais são mais clones que cópias, porque não há aparente perda de informação física: objetos digitais são caraterizados, desse modo, pelo que poderíamos chamar de paridade derivativa. No caso de objetos tradicionais, por outro lado, a criação do derivativo necessariamente carrega consigo alguma perda de conteúdo físico.

A paridade derivativa a que se refere aqui o autor é uma vantagem do digital, pois quando o processo ocorre com os "derivados" do objeto impresso ou tradicional há sempre alguma perda de conteúdo físico. Define-se aqui conteúdo físico como a informação que é encontrada na constituição física do objeto, diferentemente de seu conteúdo intelectual. Recobre-se de grande importância para as revistas eletrônicas tal definição, pois é sob este ambiente que tais publicações operam, do ponto de vista de produto e enquanto virtualização e expansão contínua e ultra-veloz do conhecimento para seu público (o pesquisador e/ou cientista). 
Assim, o virtual, no seu sentido filosófico, é o conhecimento enquanto potência e não em ato, existindo sem estar presente, adormecido, passível de a qualquer momento aparecer a partir do clique ou interesse de um pesquisador em iniciar um estudo sobre (e sob) aquele texto digital. Sob o grande fluxo de informação de um mundo globalizado e movido por uma nova tribalização, cabe muito bem a pergunta que certa vez formulou o crítico Gonzalo Auza (1997: 1): “... poderia ocorrer que em definitivo apreendamos a idéia da saudade de que uma cultura do livro é só um sintoma da sensação de perda que suscita a morte de um paradigma vital: a do individualismo em favor de uma nova tribalização, a da massa pelo indivíduo ?" Assim, será que a cultura linear da leitura do livro e do uso da biblioteca se manterão pari passo com outros suportes ou poderá ocorrer de estarmos apenas no início de uma revolução paradigmática pela qual os hábitos humanos terão uma alteração radical e profunda ? Realmente, essas questões permanecem, pois novos hábitos têm se instalado enquanto que as velhas formas de aquisição do conhecimento permanecem quase intocadas...

\subsection{O mercado de publicações periódicas científicas}

... A própria lógica do mercado da informação exige uma contínua dilatação deste, e proporciona que tudo, de qualquer maneira, se torne objeto de comunicação. Esta multiplicação vertiginosa da comunicação, este tomar a palavra por parte de um número crescente de subculturas, é o efeito mais evidente dos "mass media", e é também o fato que - relacionado com o fim, ou pelo menos com a transformação radical, do imperialismo europeu - determina a passagem de nossa sociedade à pósmodernidade. (VATTIMO, 1992: 11-12).

A globalização, como apontam os autores citados na primeira parte do análise teórica deste estudo, trouxe consigo maiores níveis de complexidade no processamento da informação, o que tem acarretado dificuldades diversas para países em desenvolvimento - ao invés do que poderia se supor. Estas dificuldades residem justamente no alinhamento de suas economias e sociedades num novo contexto sócio-econômico, caracterizado por uma sociedade informacional.

Este desalinhamento entre as diferentes regiões do globo e internas a cada país, sentido por disparidades sócio-econômicas diversas, é agravado pelas mudanças no fluxo da produção do conhecimento científico e, sobretudo, devido às alterações ocorridas com as publicações científicas eletrônicas, contribuindo para o fenômeno da infoexclusão. No caso da Internet, defrontamo-nos com uma faca de dois gumes, pois, como comenta ATAÍDE (1997), sua natureza permite que as informações sejam colocadas de forma desorganizada e 
conseqüentemente de difícil recuperação, onde “... grupos poderão se juntar e criar sites com informações organizadas, com valor agregado, estratégicas e disponíveis... a quem puder pagar por elas".

Não foi apenas a hipertextualidade que, a partir de um determinado momento histórico, outorgou às publicações periódicas eletrônicas um lugar de destaque nas comunidades científicas. Fatores econômicos impulsionaram os grandes agentes distribuidores ou agregadores a contribuir para que o mercado de publicações impressas periódicas entrasse em uma crise sem precedentes mundo afora e aflorassem as publicações eletrônicas.

Como relatam diversos autores, tal comportamento econômico do mercado ocorreu sobretudo nos últimos anos. Entre estes trabalhos, podemos citar os relatos de Brakel (1995), Schauder (1994), Collins \& Berge (1994), Meyer (1997) e Rogers \& Hurt (1990), que levantam as possíveis causas para esta crise das publicações impressas e a explosão de sua contrapartida eletrônica:

- a ineficiência do modelo tradicional. as informações científicas chegam ao seu público-alvo através de outros meios antes de sua efetiva publicação. Assim, quando o artigo é publicado este não representa uma novidade (BRAKEL, 1995);

- limites físicos: alguns artigos, que poderiam trazer informações novas e relevantes, acabam não sendo publicados, por falta de espaço nos periódicos impressos. Esta é a opinião obtida em uma pesquisa, na qual $35 \%$ dos acadêmicos entrevistados afirmam defrontaremse com o problema (SCHAUDER, 1994);

- alta especialização e baixa circulação: há uma tendência mundial que torna o número atual de periódicos excessivo (algo típico da explosão informacional, característico das sociedades atuais), onde cada qual, com raríssimas exceções, têm um público extremamente limitado e elitista de leitores. É o caso, por exemplo de um pequeno grupo de revistas altamente conceituadas, porém elitistas, quanto a quem e o que se publica nestas, como são o caso dos periódicos Nature, New England Journal of Medicine e Science, apenas para citar três exemplos.

- altos e crescentes custos: a própria especialização e dificuldades ligadas à editoração forçam as publicações a terem tiragens pequenas, resultando num baixo número de assinantes, criando-se assim um círculo vicioso que contribui para a elevação de custos e a inflação dos preços observados - vide os trabalhos de Brakel (1995), Schauder (1994) e Meyer (1997) e sobretudo Odlyzko (1997);

- falta de espaço para armazenamento nas bibliotecas: problema vivenciado quotidianamente sobretudo nas grandes universidades brasileiras, a falta de espaço para 
periódicos impressos pode representar um gasto extra nos orçamentos locais. Assim, até o espaço particular para consulta dos pesquisadores acaba sendo, de um modo ou de outro, afetado. Conforme aponta Leo Cunha (1997a, p. 81), “(...) Cada metro quadrado extra nas bibliotecas representa um gasto aproximado de US\$ 95,00 “(ROGERS \& HURT, 1990).

No caso dos grandes agentes distribuidores, encontramos um mercado globalizado caracterizado pela existência de um oligopólio ou monopólios onde exercem o poder duas ou mais empresas distribuidoras fornecendo diversificados serviços de informação, entre eles periódicos científicos.

Paralelamente a este cenário, na literatura especializada encontramos uma preocupação e interesse crescentes sobre a publicação eletrônica, como relatam, entre tantos, os estudos de: Meadows (1979); Harrison \& Stephen (1995); Barreto (1998); ou ainda uma bibliografia extensiva publicada periodicamente por Bailey Jr. (2001). Para uma definição mais precisa dessa literatura, é importante ressaltar que nos estudos existentes há grande confusão na adoção e uso indiscriminados de certos termos, representando conceitos essenciais para pesquisas envolvendo as revistas científicas eletrônicas.

Como exemplo, o estudo de Olsen (1994) fez uma pesquisa de campo onde foi analisada uma amostra de quarenta e seis estudantes e pesquisadores de uma grande universidade norte-americana cobrindo três grandes áreas do conhecimento (humanas, exatas e sociológicas), sendo composta por estudantes de literatura, química e sociologia, respectivamente. Entre os resultados do estudo, Olsen (1994: 15) descobriu como principais razões para o crescimento do uso de periódicos eletrônicos as seguintes razões, arroladas na tabela a seguir :

\begin{tabular}{||c|c|c|c||}
\hline \multicolumn{1}{|c||}{ Razões para uso de Periódicos Científicos } \\
\hline \multicolumn{1}{|c|}{ Fatores } & $\begin{array}{c}\text { Químicos } \\
(n=16)\end{array}$ & $\begin{array}{c}\text { Sociólogos } \\
(n=16)\end{array}$ & $\begin{array}{c}\text { Humanistas } \\
(n=14)\end{array}$ \\
\hline $\begin{array}{l}\text { Reunir conhecimento para a sua } \\
\text { formação em um dado assunto }\end{array}$ & 16 & 16 & 14 \\
\hline $\begin{array}{l}\text { Manter permanente consciência de } \\
\text { novos fatos / estudos }\end{array}$ & 16 & 16 & 14 \\
\hline Busca de informações específicas & 16 & 16 & 14 \\
\hline
\end{tabular}

Tabela 1: Razões para o uso da literatura de periódicos científicos 
Os resultados comprovaram, para a totalidade dos entrevistados, a alta importância da literatura periódica, considerada 'indispensável' para seus trabalhos acadêmicos. Sua utilização foi justificada pelos pesquisadores, conforme expõs Olsen (1994: 14), para mantê-los atualizados com o que outros pesquisadores vêm fazendo, para formar novas idéias, para reunir conhecimento para a formação em sua área, para observar novos fatores, atos e métodos de trabalho.

Sobre periódicos eletrônicos, Khouri (1997), citando Payne (1997), define a coleção digital ou eletrônica como sendo composta por: a) registros bibliográficos on-line descrevendo coleções físicas da biblioteca; b) produtos informacionais eletrônicos organizados localmente; c) pontes de acesso (recursos hipertexto) a outros recursos on-line remotos avaliados e disponibilizados; e d) coleções digitais locais.

\subsubsection{O agente distribuidor Ebsco}

Outro agente existente no mercado brasileiro aqui analisado foi a Ebsco International, com seu escritório sede em Birmingham, Alabama, nos Estados Unidos. Em termos cronológicos, a Ebsco foi criada a partir da capitalização de um negócio da já então existente Ebsco Industries (nascida em 1943) - que atua ainda hoje em outros ramos da economia - e era conduzido por dois rapazes: Tim e Jerry. Eles então tiveram condições financeiras para impulsionar a venda das Popular Magazine Reviews (PMRs), um sucesso no mercado naquela época, e efetivaram um acordo para as vendas desta com a Ebsco em 1985. Nascia aí o ramo da Ebsco para periódicos e bases de dados. Mais tarde, nos anos 30, foi criada uma divisão especializada na comercialização de assinaturas de periódicos científicos, e que desde então foi crescendo até tornar-se o que hoje é a Ebsco International.

A empresa possuía um faturamento anual em 1997 de US\$ 1 bilhão. Além disso, a corporação opera em dezenove países (assim como a Swets Blackwell), através de trinta e um escritórios regionais, empregando cerca de 4.500 empregados.

\subsubsection{O agente distribuidor Swets Blackwell}

O primeiro agente analisado presente no mercado brasileiro foi a Swets \& Zeitlinger. Historicamente, a Swets foi fundada em 1901 por Adrian Swets e Heinrich Zeitlinger que abriram uma livraria em Amsterdã (Holanda), especializada em livros científicos. Mais tarde, nos anos 30, fora criada uma divisão especializada na comercialização de assinaturas de periódicos científicos, e que desde então foi crescendo até tornar-se o que hoje é a Swets Blackwell. Na realidade, esse nome advém de uma fusão da anterior Swets com outra gigante do setor, a britânica Blackwells, ocorrida em idos de 1999. Após este, outro fato importante foi a fusão, dois anos depois em agosto de 2001, da já constituída Swets Blackwell com a 
Martinus Nijhoff International, com a compra deste outro grande agente do mercado internacional de periódicos. (SWETS BLACKWELL, 2001).

É interessante notar que a empresa se autodenomina como "a maior distribuidora e provedora de serviços de informação científica e profissional do mundo", e possuía um faturamento anual em 2000 de US\$ 965,73 milhões de dólares. Além disso, a corporação opera em dezenove países, empregando cerca de 1.200 empregados $^{8}$.

Não chega a ser uma surpresa o fato de que em seu próprio site há expressa a intenção de incorporar ou comprar outros menores e médios agentes distribuidores de periódicos, denotando uma clara estratégia oligopolista, algo que caracterizou esse setor desde o seu surgimento, no início do século: durante menos de cem anos, foram feitas dezenas de incorporações, somente nesta grande empresa.

A figura a seguir apresenta um organograma da Swets-Blackwell, contendo todas as suas divisões e serviços espalhados pelo mundo :

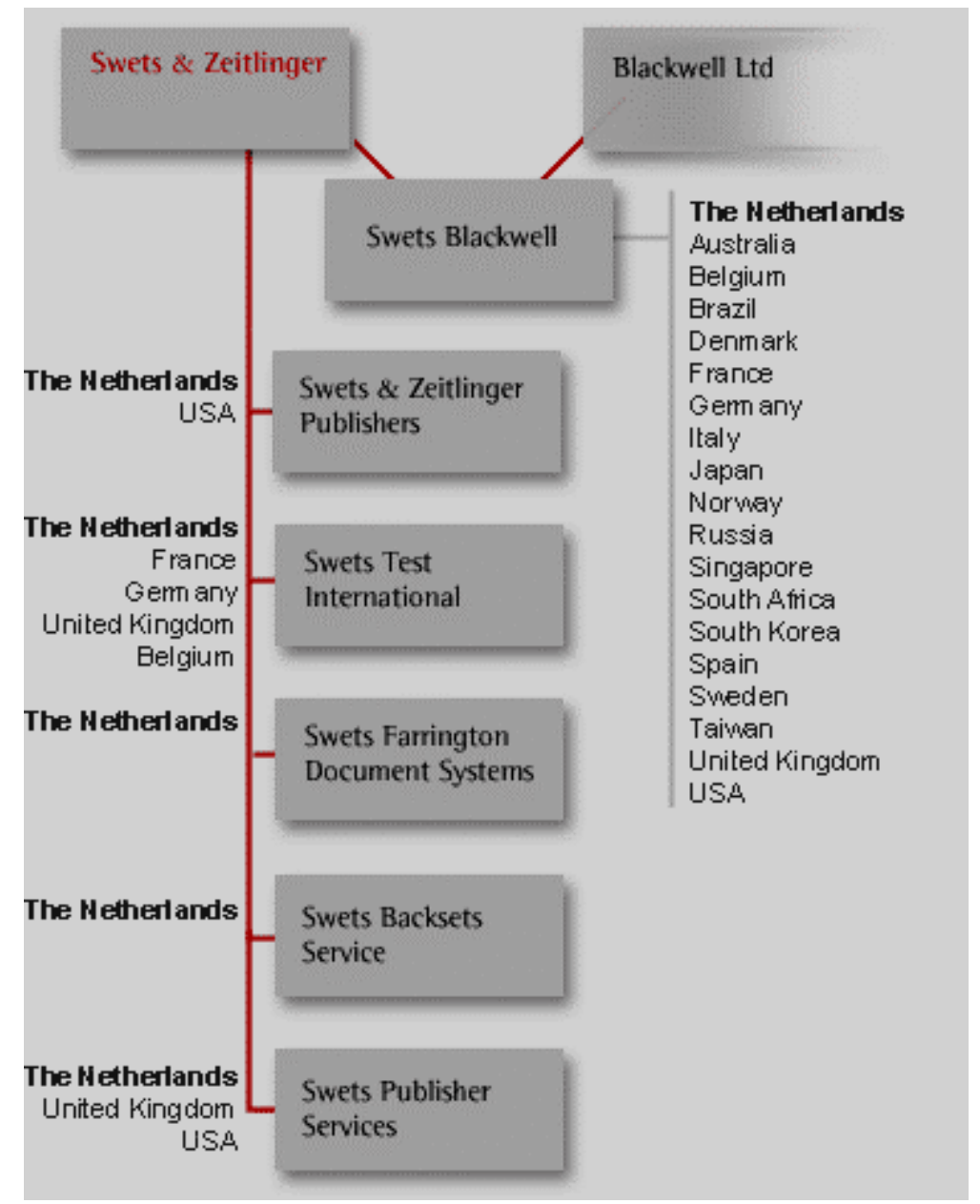

Figura 2 : Organograma da empresa Swets Blackwell Co. ${ }^{9}$

8 Disponível em: http://www.swets.nl/news010.htm. Acesso em 04/09/01.

9 Idem. 
O que se tem visto nos últimos dez anos é uma tendência dos agentes distribuidores adquirirem em algum momento uma - ou diversas, como é mais comum - editoras, e aí a própria definição de cada um deles torna-se difícil e gera freqüentes discussões para o senso comum (como é o caso da Swets Blackwell). Eles geralmente possuem, conforme bem ilustra o gráfico acima, determinadas subdivisões em suas empresas, cada qual correspondendo a um setor de serviços específico, porém complementares um ao outro: a) a(s) grande(s) editora(s); a empresa distribuidora de documentos(s); b) a empresa voltada ao atendimento dos usuários finais (bibliotecas - em sua maior parte, consórcios e pesquisadores individuais); c) a empresa responsável por vendas; d) e uma subdivisão menor (em número de funcionários) correspondendo à parte responsável pela gerência geral do negócio e as finanças gerais da grande empresa ou corporação.

\subsubsection{Outras iniciativas}

Em oposição à forte presença desses oligopólios, surgem as Free Libraries, baseadas no acesso livre e irrestrito, e cujos melhores exemplos na atualidade são a Public Library of Science e o projeto brasileiro Scielo ${ }^{10}$ (Scientific Electronic Library Online).

Um debate ocorrido em 2001, publicado na revista Nature (SECTION WEBDEBATES, 15/05/2001), colocou em xeque a natureza do negócio de publicações científicas das grandes editoras. Na essência dessa polêmica, há uma questão fundamental: deveria a literatura científica, e seu arquivo permanente de idéias e descobertas (tornado cada vez mais digital), ser propriedade privada e controlada?

O progresso científico e uma sociedade democrática e socialmente mais eqüânime só teriam a ganhar se tal literatura fosse pública, acessível e utilizável por qualquer um, sem quaisquer taxas ou restrições. É nessa direção que aponta a organização sem fins lucrativos denominada Public Library of Science (http://www.publiclibraryofscience.org/ ), a qual já acolheu mais de 29.000 assinaturas de cientistas e cidadãos comuns simpatizantes de mais de 175 países até janeiro de 2002. (PUBLIC LIBRARY OF SCIENCE, 2002). Um artigo a ser consultado a respeito desse projeto e que bem polemiza a questão é o de Eisen \& Brown (2001).

\subsection{O desenvolvimento de coleções}

Usando-se das palavras de Waldomiro Vergueiro (1987: 197), em sua oportuna interpretação ao texto de Evans (1995), podemos definir o processo de desenvolvimento de coleções como sendo

\footnotetext{
${ }^{10}$ Disponivel em http://www.scielo.org/. Acesso em 12/06/2001.
} 
... o processo de identificação dos pontos fortes e fracos de uma coleção de materiais de biblioteca em termos de necessidades dos usuários e recursos da comunidade, e tentando corrigir as fraquezas existentes quando constatados, o que vai requerer constante exame e avaliação dos recursos da biblioteca e constante estudo tanto das necessidades dos usuários como de mudanças na comunidade a ser servida.

Em sua última edição, revista e ampliada, Evans (1995: 16) extende sua definição acrescentando que “... o desenvolvimento de coleções é o processo de identificação das necessidades de informação de uma população (um serviço à população) de uma maneira temporal e economicamente adequada usando-se dos recursos de informação localmente armazenados, bem como dos de outras organizações ou bibliotecas".

Assim, essa nova definição é mais ampla em escopo e dá ênfase em uma formação de coleção bem mais reflexiva (temporal e economicamente), e na busca tanto de recursos de informações externos como internos. Considerado como um processo contínuo e ininterrupto, o desenvolvimento de coleções é visto desse modo como um processo sistêmico e dinâmico, onde cada elemento ou subprocesso tem sua importância e a importância maior ou menor deste ou daquele componente (aquisição, estudo de comunidade) irá variar de acordo com o tipo de biblioteca ou até mesmo as carências específicas apresentadas pela coleção de uma biblioteca ou centro de informação.

Seguindo o modelo de EVANS, podemos observar a importância para a biblioteca do desenvolvimento de coleções - e a distinção de seus componentes - ao mostrarmos as duas figuras a seguir (figuras 3 e 4 , respectivamente). 


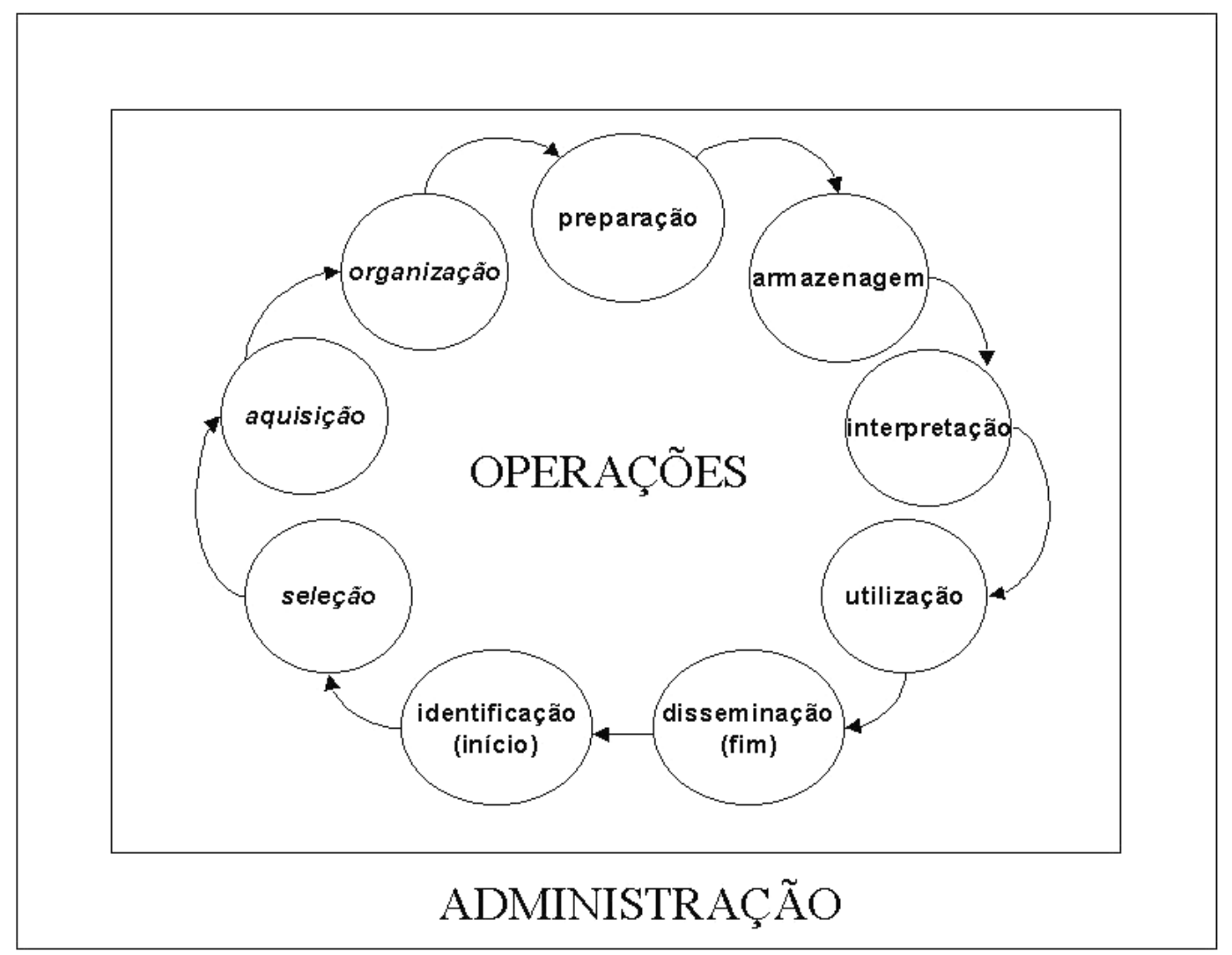

Figura 3: Fluxo de transferência da informação, transcrito do original, conforme o estudo de Evans (1995:16).

O relacionamento evidencia que o desenvolvimento de coleções envolve três dos nove elementos do fluxo de transferência da informação (identificação, seleção e aquisição). Vergueiro (1990: 43) faz uma adequada correlação ao apontar que, exceção feita à etapa de aquisição - todas as outras devem tomar como subsídio as necessidades da comunidade a ser servida, ou pelo menos deveriam fazê-lo. Podemos tomar o desenvolvimento de coleções como um único processo, sistêmico, embora, principalmente nas bibliotecas brasileiras, haja maior ênfase e preocupação em dois dos subprocessos envolvidos (seleção e aquisição), e muitas vezes - mesmo em grandes bibliotecas acadêmicas - o restante seja completamente colocado num segundo plano, ou ainda só exista no papel, enquanto política, ficando à mercê de uma nova administração que possa enxergar o todo. Isto reflete duas das posturas mais comuns e dominantes praticadas em nossas bibliotecas universitárias, e para uma visão sistêmica não podem ser consideradas como ideais. 


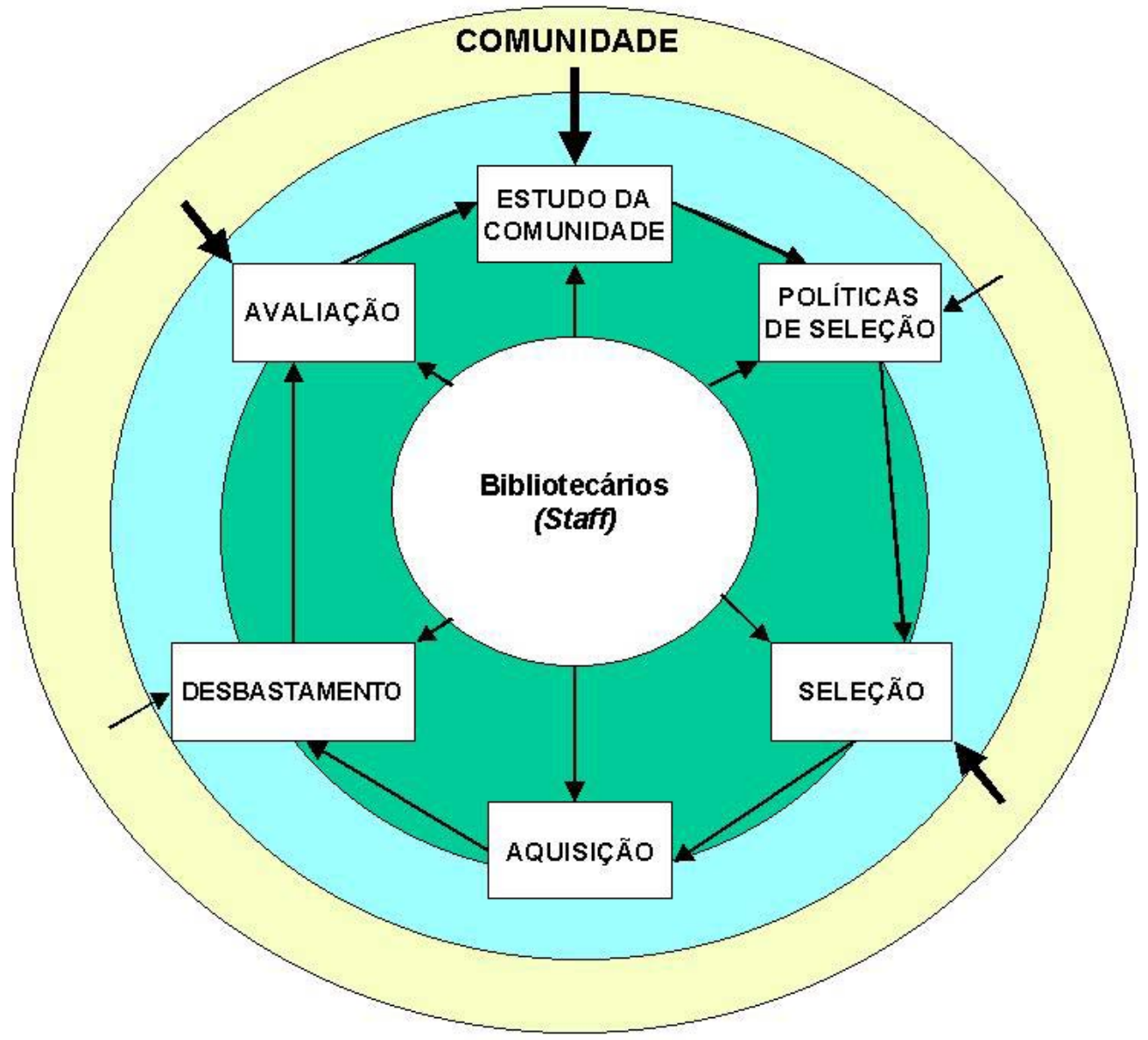

Figura 4: Processo de desenvolvimento de coleções, transcrito do artigo de Vergueiro (1987), a partir de modelo originalmente feito por Evans (1979), em sua primeira edição.

Como apontou certa vez Bryant (1987: 111-122), citada por Vergueiro (1990: 45), podemos identificar tais posturas como, pelo menos em parte, sendo:

a) uma postura de aquisição, caracterizada pela confiança na seleção de novos materiais realizada externamente à biblioteca. É, praticamente, uma postura em que os bibliotecários exercem pouquíssimo controle sobre a coleção, pelo menos no sentido de direcioná-la para um determinado objetivo. Existe apenas, como indício da existência do mesmo, no máximo um perfil para aprovação do material, estabelecido em bases bastante amplas.

b) a postura de seleção procura concentrar nos bibliotecários a responsabilidade pelo desenvolvimento da coleção, apesar de que seleções realizadas externamente à biblioteca podem ser aceitas ou, mesmo, eventualmente solicitadas. Existe um tipo de ligação entre usuários e bibliotecários responsáveis pela seleção. Isto, geralmente, facilita o estabelecimento de uma política para o desenvolvimento da coleção, embora se possa afirmar que as atividades rotineiras de seleção tendem a 
deixar, aos bibliotecários, pouco tempo disponível para participação no desbastamento sistemático ou outros projetos.

A análise ou estudo das necessidades da comunidade a ser servida, muitas vezes deixada em um segundo plano ou tomando os bibliotecários de desenvolvimento de coleções decisões de aquisição que não se relacionam mínimamente com os resultados obtidos em seus estudos de uso, deve considerar não somente a comunidade ativa - e portanto, mensurável através das últimas estatísticas feitas - mas também, e sobretudo, considerando-se o público potencial da biblioteca e o contexto econômico e político no qual esta se insere, como é o objeto deste estudo.

No caso, deparamo-nos com as consequências da globalização e o crescente 'digital divide' a que os cientistas brasileiros encontram-se sujeitos, num mercado de publicações científicas que não privilegia a produção de países em desenvolvimento. Nesse sentido, as bibliotecas têm utilizado como um instrumento as políticas de desenvolvimento cooperativas, de modo a buscar maximizar seus recursos e oferecer um leque cada vez maior de informações a seus usuários, onde esses recursos são agora cada vez mais oferecidos no formato eletrônico.

\subsubsection{Políticas de desenvolvimento de coleções e atividades cooperativas}

Antes de mais nada, faz-se necessária uma definição do que venha a ser o estabelecimento de uma política de desenvolvimento de coleções e no que ela difere das etapas operacionais do processo de desenvolvimento de coleções. Conforme bem claramente expôs Vergueiro (1987:197-98) em seu artigo,

As razões para elaboração de uma política de desenvolvimento da coleção parecem mais que evidentes, a começar por razões econômicas, embora não se possa - ou não se deva - pensar em elaborar políticas apenas tendo como alvo a provável economia de recursos que se poderia conseguir por seu intermédio. (...) Feng (1979: 40) levanta as razões que norteiam a elaboração de uma política para o desenvolvimento da coleção. São elas: 1. O próprio processo de elaboração do documento propicia oportunidade de auto-avaliação e reflexão; 2. tal documento garante uma coleção consistente e crescimento balanceado dos recursos da biblioteca. Ou seja, a política irá funcionar como diretriz às decisões do bibliotecário em relação à própria administração dos recursos informacionais. É ela que irá prover uma descrição atual da coleção, apontar o método de trabalho para consecução dos objetivos e funcionar como elemento de argumentação ao bibliotecário, dando-lhe subsídios para discussão com autoridades superiores, tanto para a obtenção de novas aquisições como para recursa a imposições estapafúrdias. 
O documento de política de desenvolvimento de coleções exige bom planejamento e ótimo conhecimento do acervo e área do conhecimento em que se encontra inserida a biblioteca, bem como o tipo de biblioteca para o qual tal política é elaborada (pública, especializada ou acadêmica). Atualmente, além das diretrizes estabelecidas desde 1977 e revistas pela ALA American Library Association, existem outras que merecem destaque e duas delas são o RLG Conspectus, escrito pelo Research Libraries Group (GWINN \& MOSHER, 1983: 128-40), e responsável por orientar inúmeros projetos em bibliotecas acadêmicas espalhadas pelo mundo; e a elaborada por Evans (1995), que difere-se pouco das da associação americana de bibliotecas - American Library Association (ALA).

Podemos nos perguntar então no que o desenvolvimento de coleções se difere quando tratamos do desenvolvimento de coleções para bibliotecas que desenvolvam algum tipo de atividade cooperativa (desde cooperações envolvendo empréstimos inter-bibliotecas até grandes consórcios). Para abordar estes aspectos, é necessário abrir aqui um parêntesis e tecer alguns comentários gerais importantes sobre as tipologias de modelos de atividade cooperativa existentes. Como bem ilustrou Michael Sinclair, em seu artigo "Uma tipologia de bibliotecas cooperativas", podemos arrolar a existência de pelo menos quatro modelos teóricos de atividade cooperativa distintos. Embora sejam utilizados os conceitos de Sinclair, grande parte das interpretações para uma melhor compreensão das idéias básicas expostas neste estudo são extraídas da obra de Evans (1995: 457-8). Neste modelo téorico são apresentadas então quatro formas (A, B, C e D) de atividade cooperativa, caminhando da mais simples $(A)$ à mais complexa $(D)$. 


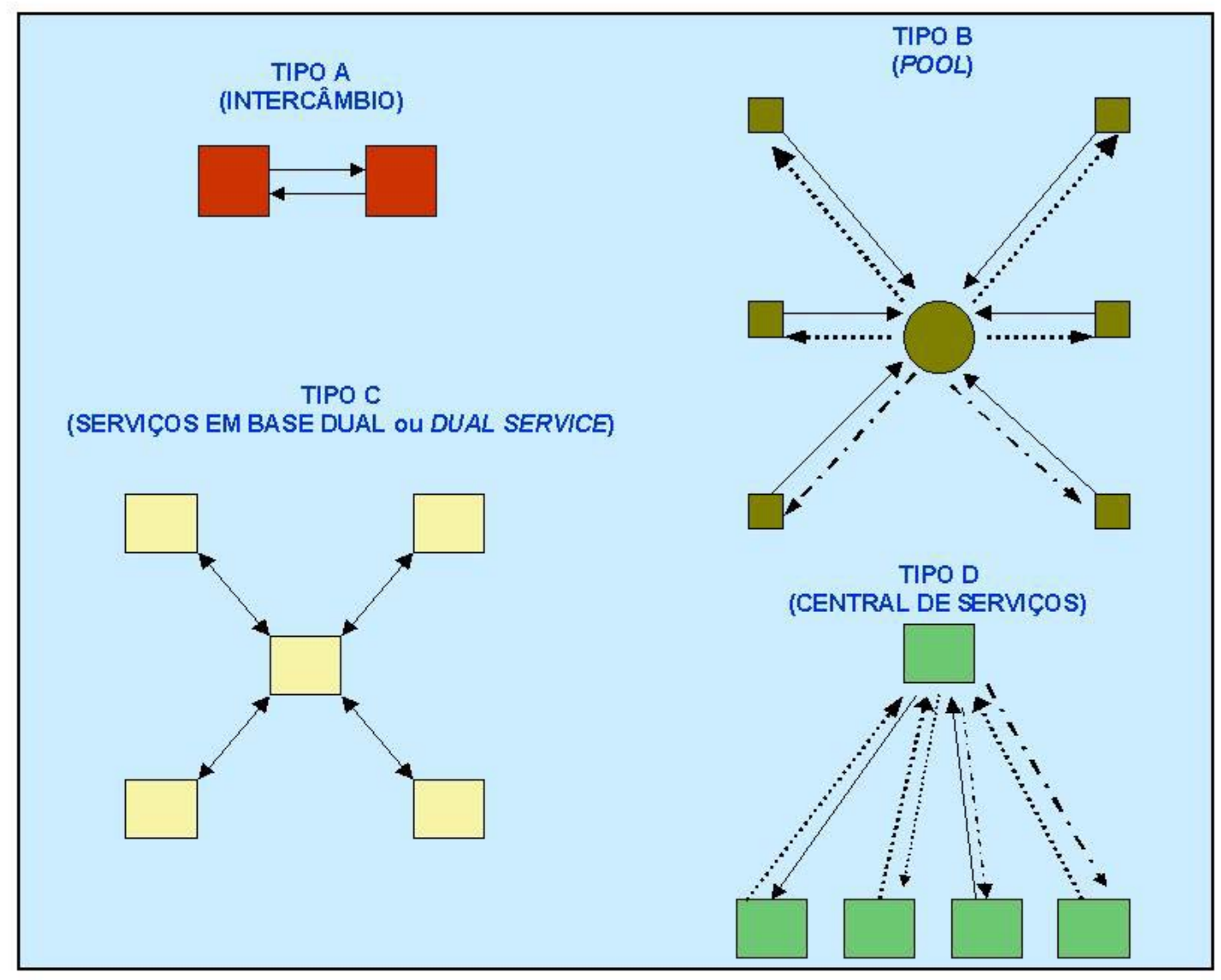

Figura 5: Modelos de atividade cooperativa. Adaptação do gráfico de M. P. Sinclair (1973), citado em Evans (1995: 458).

Conforme bem ilustra a Figura 5 acima, o tipo A é o modelo mais simples de intercâmbio e funciona de modo bilateral, no qual apenas duas bibliotecas compartilham materiais e serviços informacionais. Na prática, ambas as bibliotecas calculam a taxa ou custo de intercâmbio de acordo com algum valor aprovado em um acordo formal (por exemplo, um para um ou dois para um); com certa frequência, há uma revisão anual desta taxa através dos resultados anuais obtidos entre as duas bibliotecas cooperantes. Embora não se tenha notícia se esse modelo já foi vigente no Brasil no passado, algumas bibliotecas universitárias americanas praticam tal fórmula, segundo Evans (1995: 457), como entre as bibliotecas da Universidade de Loyola Marymount em acordos de serviços de empréstimo. Outro caso bastante citado é o programa de bibliotecas californiano Ohio Link e Link+, típicos programas de empréstimo interbibliotecário tradicionais.

No modelo de tipo $B$, na realidade um desenvolvimento do modelo $A$, temos um modelo em pool ("pooling model"). Neste, sempre mais do que duas bibliotecas compartilham seus recursos (financeiros, informacionais, de infra-estrutura), sempre bilateralmente. Muitos 
dos primeiros sistemas cooperativos foram deste tipo; em certo sentido, o OCLC - Online Computer Library Center - um dos maiores catálogos cooperativos de que se tem notícia, começou como um pool.

No modelo do tipo C, o modelo de serviços em base dual, duas ou mais bibliotecas participantes tomam vantagem das facilidades de um outro participante - geralmente uma biblioteca de maior porte. Se tomarmos como exemplos os diversos serviços cooperativos de empréstimo inter-bibliotecas de universidades brasileiras, temos exemplos bastante sólidos produzindo resultados expressivos neste campo, como é o caso da rede de bibliotecas cooperantes do Centro Latino-Americano de Ciências da Saúde, ou mais conhecida como Rede Bireme. Exemplificando, outro dos possíveis resultados vistos é um serviço OPAC (Online Public Access Cataloguing). Este tipo de atividade cooperativa distingue-se da seguinte (o tipo D), pois o termo 'modelo de serviços em base dual' (uma livre tradução aqui para "dual service") enfatiza o fato de que todos os participantes, incluindo o elemento facilitador (ou maior biblioteca) contribuem para os resultados do trabalho cooperativo.

Finalmente, temos o modelo $D$, a central de serviços, onde um número de bibliotecas se utilizam dos serviços de uma organização para facilitar a entrada e processamento de materiais às bibliotecas cooperantes individualmente, considerando suas características individuais.

Nos consórcios geralmente encontrados em países em desenvolvimento, o tipo de atividade cooperativa mais comum é aquele do tipo $C$, sobremaneira através de serviços de empréstimos interbibliotecas e dependente de uma biblioteca de grande porte, em um fluxo de trabalho bidirecional, e não por acaso bastante abordado em nossa literatura.

Numa atividade cooperativa, existem seis elementos gerais que podem ser elencados como benéficos. Segundo Evans (1995:460), o primeiro deles é "o aumento potencial de acesso à informação, ampliando-se o senso de tornar disponível um maior escopo de materiais ou melhorar as coleções em profundidade, ou seja, aprimorar seus recursos informacionais cada vez mais específicos em uma determinada área do conhecimento". Um bom exemplo é o de compartilhamento consorciado, onde cada novo membro contribue com $30 \%$ a $40 \%$ em novos títulos - caso do OHIO Link and Link+); O segundo deles é que é possível agregar novos e estender os limitados recursos de uma biblioteca-membro. Muitas vezes, as pessoas vêm a cooperação como uma maneira de economizar dinheiro. Para Evans (1995: 460), "a cooperação não economiza dinheiro para uma biblioteca. Se duas ou mais bibliotecas combinam seus esforços, elas não gastarão menos dinheiro"; um efetivo programa cooperativo, para o autor, simplesmente divide o trabalho e compartilha os resultados, sejam eles positivos e/ou negativos, e isso de fato é uma realidade como é analisado no estudo de caso desta dissertação. 
O terceiro elemento benéfico é o compartilhamento de resultados levando os componentes da atividade cooperativa a alguns benefícios, tais como a maior especialização de pessoal, assim como acontece - dando um exemplo local - com o consórcio ProBE. Em um lado ou frente, um membro do consórcio, a UNIFESP - através da equipe de bibliotecários da BIREME, direcionou a formação profissional de seu pessoal aproveitando-se de seu background para atividades de suporte ao gerenciamento e operacionalização das coleções eletrônicas disponibilizadas pelo consórcio; por outro lado ou frente de trabalho, membros da USP e UNESP direcionaram seus esforços sobretudo dando suporte e insumos na análise das políticas e decisões envolvendo questões contratuais e de garantia dos "backfiles" (volumes de periódicos de edições de anos anteriores ao corrente) para o consórcio como um todo, através do seu comitê coordenador. Essa especialização de cada membro integrante produz uma melhora no todo.

Um quarto benefício, que pode estar atrelado à existência do anterior (embora não obrigatoriamente), é a redução de uma duplicação desnecessária com o compartilhamento, pois afloram as coleções comuns, por mínima que seja uma análise comparativa que estas possam ser submetidas. Planejadores deveriam estudar exatamente quanto em termos de duplicação de coleções eles podem eliminar antes de desenvolverem um acordo de cooperação formal. Vagas discussões sobre redução da duplicação, sem um estudo em profundidade da situação, como argumenta Evans (1995: 460), usualmente levam a altas expectativas e, todas, com grande frequência também, a esperanças frustradas. Todavia, a duplicação reduzida com o descarte de itens de baixo uso é um real benefício potencial e perfeitamente mensurável.

Um marketing ativo atuando como unificador e, indiretamente, facilitador de pontos de acesso a serviços para usuários, é um quinto benefício bastante comum nos dias atuais, sobretudo com os sistemas de acesso online, como catálogos de periódicos eletrônicos disponíveis na Rede no país (consórcio CAPES, consórcio ProBE, outros portais etc.). Um último benefício, segundo Evans (1995:460), seria o incremento em relações de trabalho entre bibliotecas cooperantes, geralmente este pouco discutido na literatura. Bibliotecários e técnicos podem ganhar uma melhor perspectiva a respeito dos problemas de outras instituições - e mesmo equacioná-los, como um resultado do trabalho cooperativo em problemas mútuos que até então eram desconhecidos entre os próprios membros. Também podem aprender com problemas específicos enfrentados por outros tipos de bibliotecas e, assim, saber o que fazer para seu pessoal enfrentar esse tipo de situação, caso apareça.

Mas o grande desafio para uma atividade cooperativa, e a razão para a qual esta chega a despertar certo temor inicial, são as questões e problemas envolvidos. Seguindo o modelo de Evans (1995: 464), estes podem ser subdivididos como sendo de seis tipos: a) 
institucionais; b) legais, políticos e administrativos; c) tecnológicos; d) físicos; e) de pessoal; f) baseados no conhecimento.

A) Questões institucionais : A primeira questão institucional envolvendo uma biblioteca tradicional, especialmente bibliotecas acadêmicas, tem sido a auto-suficiência de suas coleções. É cada vez maior a evidência para todos os bibliotecários que esta meta é impossível, ainda mais nos dias atuais. Em um artigo publicado em 09.09.1994 no periódico Library Hotline, os autores deste mostraram que a British Library está desistindo de coletar e armazenar todas as edições de todos os livros, revistas e periódicos impressos na Grã-Bretanha.

Conforme bem expõe Evans (1995: 463), se os gigantes do mundo das bibliotecas estão desistindo de suas auto-suficiências locais e que remontam a séculos de tradição nas políticas de bibliotecas nacionais e até hoje geram grandes discussões no meio, o que podem outras bibliotecas, de mais modestos recursos, conseguir?

Bibliotecários devem estar cientes que sempre haverá falhas na sua coleção, e que algum pedido não será atendido e, portanto, necessitarão de empréstimos interbibliotecas ou alguma forma de distribuição de documentos para cobrir esta lacuna. Entretanto, usuários tradicionalmente não adoram os serviços de empréstimos interbibliotecas, e assim eles são uma constante fonte de pressão na biblioteca para ser auto-suficiente.

As bibliotecas não podem atender a todos os questionamentos feitos por seus usuários a respeito da redução de suas coleções com o passar dos anos e as políticas cooperativas quando recém-implantadas, carregam consigo diversos temores para a comunidade de usuários. Fundos para compra têm diminuído ano a ano, e uma biblioteca não pode simplesmente cortar toda uma área de sua coleção ou tê-la drasticamente reduzida no ano seguinte. É aí que os esforços cooperativos podem, pelo menos em parte, ajudar a resolver tais dilemas institucionais. A cobrança quanto à existência de uma coleção extensiva é uma questão institucional que persiste atualmente, mesmo com o advento do acesso remoto a documentos digitais disponíveis na rede. Ilustrando o problema, Tom Ballard teceu uma série de considerações a respeito, em seu artigo publicado já há vinte anos, ainda atual (BALLARD, 1982: 679-83). Nele, o autor citou estudos indicando que as pessoas tendem a selecionar a partir do material já disponivel localmente em sua biblioteca no momento de suas consultas, deixando para segundo ou terceiro planos a busca pelo material desejado e localizado externamente, onde quer que este esteja, criando-se aqui um exemplo típico da "lei do menor esforço". A única exceção à descoberta, que pode ser generalizada à grande maioria de bibliotecas, sobretudo as universitárias, é quando há um serviço de empréstimo e envio de documentos num prazo máximo aceitável pelos usuários, variando de vinte e quatro a quarenta e oito horas de comunidade para comunidade. 
Outra questão institucional ganhando destaque sobretudo a partir do meio da década de noventa para cá é um fato, visto nos quatro cantos na realidade de bibliotecas universitárias, e facilmente comprovável por estudos e encontrados na literatura especializada: os orçamentos para compra de materiais informacionais estão caza vez mais arrochados. E, seguindo o raciocínio de Evans (1995: 464-65), orçamentos encolhidos significam também que há menos dinheiro disponível para financiar aquisições cooperadas de categorias de recursos informacionais passíveis de serem compartilhados. Assim, itens de baixo uso - antes de serem meros itens passíveis de de-seleção, podem ser (e em alguns consórcios, isto já ocorre) a essência de projetos de compartilhamento de recursos. Mas há situações e práticas destoantes, de acordo com um estudo de Hacken (1992: 21), no qual foi comprovado que o interesse pela formação de coleções compartilhadas era, muito menos do que ocorre na implementação, por itens de potencial interesse para a pesquisa, em oposição aos com interesse demonstrado, ou real uso.

E note-se como o contexto sócio-econômico e tecnológico alterou realidades: há vinte anos atrás, havia forte pressão entre todos os usuários pela manutenção da total autosuficiência. Nos dias atuais - meados de 2002 - muitos estão pretendendo deixar a cargo de serviços eletrônicos fornecer parte do acesso à informação, se o acesso for mais conveniente que ir às bibliotecas. Infelizmente, como notou Berry (1992: 100), citado em Evans (1995: 465),

dadas as atuais condições econômicas, o que bibliotecas e usuários querem siginificar quando falam da auto-suficiência local está mais e mais restrito em seu escopo. Bibliotecas são sortudas em [conseguir] ir ao encontro de todas as necessidades de grande demanda local, muito menos que adquirir materiais para áreas de baixa demanda. O que, por sua vez, reduz, o rol de materiais de baixo uso que poderiam ser matéria para um programa cooperativo. Em tais circunstâncias, não é surpreendente encontrar bibliotecas tendo tempos em dificuldade para a identificação de áreas que elas podem ter esquecido como terem sido localmente disponíveis.

A última das mais importantes questões institucionais que pode ser levantada aqui, sempre permanecerá presente nas bibliotecas. Conforme arrola Evans (1995: 466),

... não importa quanto dinheiro esteja disponível para desenvolver coleções locais, algum usuário imaginativo ou membro da equipe de funcionários irá pensar que uma nova área da coleção ultrapassará todos os recursos financeiros disponíveis [e assim mesmo será necessária, segundo este(s) - grifo meu]. Uma variação tanto da hierarquia de necessidades de Maslow como das leis de Parkinson é que as organizações, como pessoas, sempre excedem um pouco em sua habilidade de satisfazerem aquilo que querem. Se a necessidade local combina com o desejo por auto-suficiência local, 
bibliotecários nunca serão hábeis o bastante para concordarem totalmente com qualquer esforço cooperativo.

\begin{tabular}{|c|c|}
\hline \multicolumn{2}{|r|}{ Cronologia de consórcios no mundo ${ }^{11}$} \\
\hline Século XVII a 1887 & $\begin{array}{l}\text { Programas de associação e cooperação entre bibliotecas. Publicação de } \\
\text { importantes estudos: CAMPBELL, J.L. Grouping of places for library } \\
\text { purposes; DEWEY, M. Library Co-operation in: Library Journal; MAC, E.A. } \\
\text { Co-Operation versus Competition. }\end{array}$ \\
\hline Fins do século $X I X$ & Surgimento das Free Libraries \\
\hline 1905 & Nasce a idéia da biblioteca universal nos Estados Unidos \\
\hline Anos 30 & $\begin{array}{l}\text { Iniciativa consorciada de compra de periódicos do Triangle Research } \\
\text { Libraries Network of North Carolina. }\end{array}$ \\
\hline 1939 & $\begin{array}{l}\text { A American Library Association (ALA) publica o estudo de DOWNS, R.B.: } \\
\text { One for All: A Historical Sketch of Library Cooperation, } 1930 \text { a 1907. in:ALA } \\
\text { (The Library of Tomorrow). }\end{array}$ \\
\hline 1960 & $\begin{array}{l}\text { Forte impacto da automatização nos consórios de bibliotecas. Criação da } \\
\text { OCLC - Online Computer Library Center, visando a catalogação cooperativa, } \\
\text { fato que permitiu o intercâmbio de coleções a níveis local e mundial. }\end{array}$ \\
\hline Anos 1970 a 80 & Implantação de Sistemas Integrados de bibliotecas, sobretudo no Brasil. \\
\hline 1978 & $\begin{array}{l}\text { Report on Library Cooperation : ASLA (Association of Specialized and } \\
\text { Cooperative Library Agencies). }\end{array}$ \\
\hline 1990 & $\begin{array}{l}\text { Ressurgimento dos consórcios: fatores tecnológicos, fiscais, organizacionais } \\
\text { e políticos }\end{array}$ \\
\hline 1994 & $\begin{array}{l}\text { Publicação de importante guia sobre desenvolvimento de coleções } \\
\text { cooperativo da ALA: HARLOE, Bart. (ed). Guide to Cooperative Collection } \\
\text { Development. (ALCTS Collection Management and Development Guides, 6). } \\
\text { Chicago: American Library Association. }\end{array}$ \\
\hline 1997 & $\begin{array}{l}\text { Criação do ICOLC (The International Coalition of Library Consortia - ICOLC). } \\
\text { Importante fórum reunindo mais de } 150 \text { consórcios de bibliotecas espalhados } \\
\text { pelo mundo, serve prioritariamente instituições de nível superior. Visa facilitar } \\
\text { a discussão entre consórcios, atuando na discussão sobre: a) práticas de } \\
\text { preços dos information [global] players do mercado; b) recursos eletrônicos } \\
\text { oferecidos; e c) outras questões importantes. }\end{array}$ \\
\hline 2001 & $\begin{array}{l}\text { A compra da SilverPlatter pela Wolters Kluwer é um novo marco do controle } \\
\text { monopolístico, despertando preocupação no mundo todo ante a possibilidade } \\
\text { de crescimento injustificado de preços e limitadas opções de acesso a } \\
\text { serviços aos usuários - bibliotecas. (Cf. ICOLC, May 2001) }\end{array}$ \\
\hline
\end{tabular}

Quadro IV : Cronologia da atividade de consórcios de bibliotecas no mundo.

\footnotetext{
${ }^{11}$ Adaptado e ampliado a partir de quadro original apresentado por Rosane Taruhn, em palestra proferida no II Workshop Probe. São Paulo: PROBE, 2001.
} 
De maneira geral, a necessidade institucional por consórcios surgiu de diversos modos e com diferentes formas, e conforme salientou Hiremath (2001: 80),

... inundadas [as bibliotecas, grifo meu] pelo repentino e continuo 'assalto' causado pela tecnologias eletrônicas, parece claro que a necessidade por consórcios é sentida pelas bibliotecas, mas também que o processo por preenchimento dessas necessidades permanece incerto e idiossincrático.

\subsubsection{Panorama de consórcios existentes na América Latina}

Através de um levantamento geral dos principais consórcios de bibliotecas de instituições de ensino superior e pesquisa na América Latina, feito com maior detalhamento quando possível, devido às limitações dessa pesquisa, buscou-se contextualizar a realidade desse imenso continente, sobretudo visando traçar alguns paralelos com a realidade brasileira e enriquecer as questões levantadas nessa dissertação, através da exposição dessa rica diversidade. Tentou-se, sempre que possível, situá-los com suas respectivas datações.

\section{Consórcio Nacional de Periódicos Eletrônicos CAPES (Década 90 até hoje)}

Criado originalmente no início dos anos 90, a CAPES assumia então integralmente a responsabilidade pela compra junto aos agentes e distribuidores de periódicos científicos para as bibliotecas brasileiras. Nos primeiros dez anos, a relação da CAPES com as instituições de ensino superior (IES) foi pautada por diversos problemas, marcados sobretudo por demora e desentendimentos no repasse das verbas da CAPES a estas instiuições. Outro fato marcante desse período e que afetou a aquisição de periódicos no país como um todo foi a forte crise cambial de 1999. No dia 10 de novembro de 2000, marca-se uma mudança definitiva nos rumos desta relação, sobretudo com a entrada dos periódicos eletrônicos no mercado e a criação de uma infra-estrutura tecnológica que desse suporte ao consórcio, do início de 2000 em diante. O Consórcio Nacional de Periódicos Eletrônicos firmou então formalmente outro convênio, por intermédio do Ministério da Educação, cobrindo mais de 85 Instituições de Ensino Superior e de Pesquisa para acesso a diversos títulos. Toda articulação política foi feita pela Comissão Brasileira de Bibliotecas Universitárias (CBBU) junto à CAPES, para minimizar a carência de recursos de periódicos estrangeiros.

O portal deste consórcio, disponível no site www.periodicos.capes.gov.br, permite o acesso à oito bases de dados referenciais temáticas cobrindo as áreas de Agronomia, Biologia, Ciências dos Alimentos, Economia, Engenharia, Geociências, Letras, Lingüística e Sociologia com mais de 29.000 títulos indexados; ao índice de patentes, com 18 milhões de registros; a base geral de referência e citações, Web of Science, com 8.400 títulos indexados; 
e 1.400 títulos de periódicos científicos, com texto completo, em diversas áreas do conhecimento.

\section{SIDALC - Sistema de Informação e Documentação Agropecuário da América Latina e Caribe (1984 / 1991 até hoje)}

Tendo como homepage o site <http://sidalc.sidalcus.net/default.htm>, o SIDALC abrange toda a América Latina e Caribe. Em 1991 iniciou-se a catalogação automatizada com links para textos completos. Seu suporte financeiro é a Fundação Kellogg. Este consórcio cobre onze instituições de pesquisa, sobretudo da área de agricultura. São elas: Instituto Interamericano de Cooperación para la Agricultura (IICA) - membro e Coordenador geral ; Canadian Agricultural Library (CAL) ; Centro Agronómico Tropical de Investigación y Enseñanza (CATIE); Centro Internacional de Agricultura Tropical (CIAT) ; Centro Internacional de Mejoramiento de Maíz y Trigo (CIMMYT) ; Corporación Colombiana de Investigación Agropecuaria (CORPOICA) ; Empresa Brasileira de Pesquisa Agropecuária (EMBRAPA) ; Fundación Hondureña de Investigación Agrícola (FHIA); Instituto de Investigaciones Agropecuarias (INIA - Chile) ; National Agricultural Library (NAL - EUA) ; Universidad Autónoma Agraria Antonio Narro (UAAAN - México) ; Universidad Autónoma de Nuevo León (UANL) (México).

O Sidalc tem grande abrangência na América Latina, cobrindo os seguintes os países: Barbados, Bahamas, Bolivia, Chile, Colombia, Costa Rica, Dominica, Ecuador, El Salvador, Guyana, Haití, Honduras, Jamaica, México, Nicaragua, Panamá, Perú, República Dominicana, Santa Lucia, St. Kitts \& Nevis, Surinam, Trinidad y Tobago, Uruguay y Venezuela.

\section{InfoAndina - Sistema de Información del Codesan (Consorcio para Desarrollo de la Ecorregion Andina) - (1993 até hoje)}

Tem como homepage o site <http://www.condesan.org/infoandi/infoandf.htm>, e abrange toda a América Latina e Caribe; o suporte financeiro é realizado pelo International Development Research Centre (IDRC), do Canadá. Teve início em 1993, e tem como instituições-membro: FLACSO, AME - Equador; ABTEMA, BIOSOMA, PROINPA - Bolívia, ASPADERUC, CIP, CIRNMA, TMI-HUARAZ, CI-Peru. Desde o ano de 1996 a Infoandina é responsável pelas atividades do Foro de Montañas en América Latina (MF-LAC) <http://www.condesan.org/infoandi/foro/mf2.htm>, uma iniciativa financiada pelo órgão COSUDE.

Dentre as atividades desenvolvidas, o CODESAN apóia a difusão dos resultados de investigação entre os seus membros, mediante: publicação de boletins eletrônicos e infoNotas; design de páginas web e links para sócios do CODESAN; publicação de sumários dos fóros eletrônicos realizados, disponibilizados a partir de seu site. 


\section{Consórcio CEBPR - Consórcio de Escuelas y Bibliotecas de Puerto Rico}

Disponível na Internet através da homepage <http://www.cebpr.com/>, o Consórcio CEBPR cobre a região de Porto Rico, e tem como órgão financiador a agência americana Hispanic Information \& Telecommunications Network, Inc. - HITN. Seu período de início não foi identificado, e tem como membros as escolas e bibliotecas de Porto Rico, em lista acessível no mesmo site. Entre os serviços oferecidos disponíveis está o Bibliored (http://www.bibliored.com/).

\section{ISTEC - Consorcio Iberoaméricano para la Educación en Ciencia y Tecnología (1990 até hoje)}

Iniciado em 1990, o consórcio é um dos maiores da América Latina em abrangência e está disponível na Internet no site <http://www.istec.org>. Cobre países da Espanha, Portugal e Américas. Sua rede de bibliotecas é bastante conhecida e referenciada na literatura, o LibLink. O LibLink (library linkages - Redes de Bibliotecas) é uma das iniciativas do ISTEC para a comunidade iberoamericana. Sua meta é promover o acesso rápido à informação científica e técnica para melhorar a produtividade em investigacão e ensino. Busca “... promover também o uso de serviços compartilhados de informação em ciência e tecnología em todo o hemisfério e oferecer informação atualizada na forma adequada e rápida a uma comunidade usuária que é diversa em suas necessidades e localização geográfica". $O$ ISTEC é, como se auto-descreve,

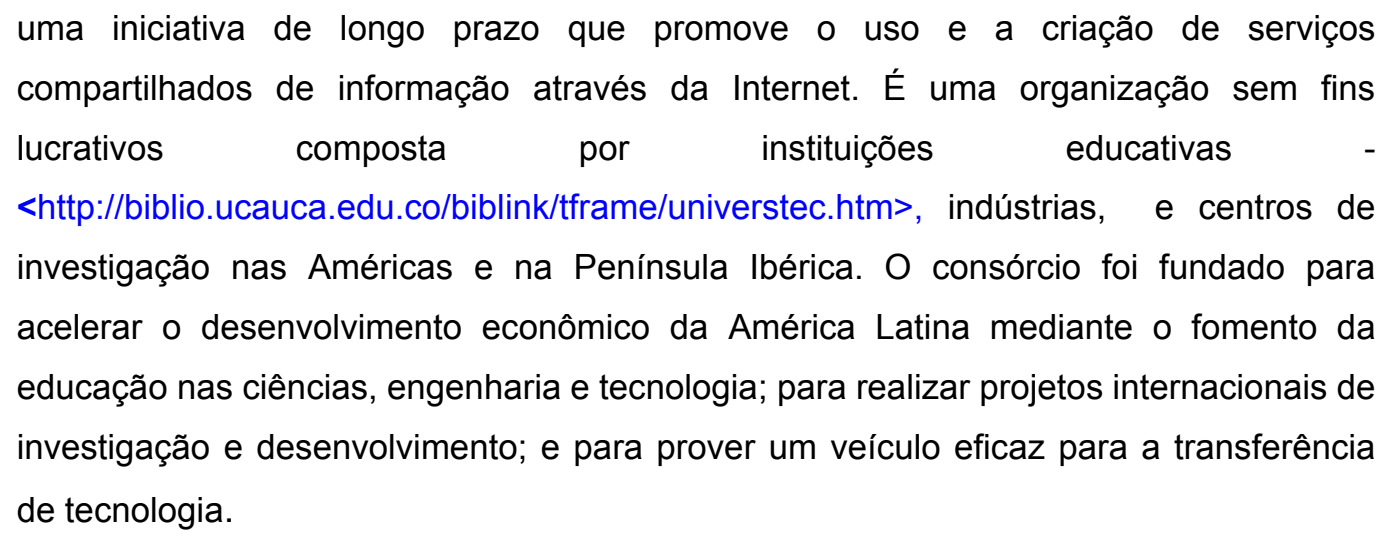

Tem como membros trinta e seis instituições, dentre elas a Universidad Mayor de San Andrés, Bolivia; Instituto de Matemática e Estatística (IME), Brasil; Instituto de Tecnologia de Aeronáutica (ITA), Brasil; Pontifícia Universidade Católica do Rio de Janeiro, Brasil; Universidad de Antioquia; Universidad Autónoma del Estado de Morelos, México; Universidad Nacional La Plata, Argentina; Universidade de São Paulo, Brasil; Universidade Estadual de Campinas, Brasil; Universidade Estadual Paulista Júlio de Mesquita Filho (UNESP), Brasil. 


\title{
6.4.3. A ação de consórcios de bibliotecas no gerenciamento de publicações periódicas científicas
}

Nos dias atuais, os projetos cooperativos adquirem importância capital, aliados a outros esforços de reengenharia de processos, visando o gerenciamento de recursos e de informação em bibliotecas universitárias. Jiménez (2001: 2-3) é oportuno ao afirmar que

\begin{abstract}
... por isso, tem sentido que as instituições estabeleçam políticas que levem à excelência como objetivo primordial e que elaborem uma metodologia para quantificar não apenas os seus resultados econômicos mas também a relação custo-benefício social de seus esforços. Se esta metodologia se coloca aos consórcios entre unidades de informação também nestas se pode medir sua utilidade econômico-social para as instituições que os integram e para o resto da sociedade. Na América Latina e Caribe, o crescimento da produtividade de seus países é indispensável para entrar e permanecer nos mercados mundiais. As tecnologias de informação são um dos fatores estratégicos de eficácia e eficiência nas organizações sociais que buscam converter-se em uma fonte de poder em si mesmas através do aumento da produção do conhecimento e sua capacidade de inovação. (...) Por isto, os consórcios estabelecidos entre unidades de informação, como um tipo de mercado em rede, (...) são por sua vez fatores-chave para alcançar níveis de produção de conhecimento um pouco mais elevados que os atuais.
\end{abstract}

As peculiaridades dos avanços tecnológicos colocam as bibliotecas e centros de informação em um novo patamar em relação à suas respectivas políticas de desenvolvimento de coleções, exigindo-lhes uma redefinição de seus modelos de gerenciamento. Isto ocorre, entre outros fatores, devido, sobretudo, a existência de uma nova sinergia entre sua forma de atuação "preventiva", baseada na posse ou aquisição física de recursos informacionais com sua outra forma de atuação, voltada ao acesso da informação, onde quer que ela esteja e visando o atendimento sob demanda, a partir do momento em que este ocorre (modelo de serviços "just in time").

No plano macroeconômico, a globalização e a infoexclusão são elementos que aumentam a responsabilidade social e exigem das bibliotecas universitárias brasileiras (e de toda a América Latina) um repensar de suas políticas de desenvolvimento de coleções. Estas serão obrigadas a se alinharem com as iniciativas de desenvolvimento de P\&D de seus respectivos países, já que o quadro latino-americano mantém-se carente de novos e fortes impulsos que fortaleçam sua produção científica, contribuindo para que estes continuem, por um lado, crescendo e propiciando maiores níveis de competitividade, e, por outro, promovendo maior equidade social, de forma a superar as respectivas limitações destas nações e alcançar patamares econômicos e sociais melhores que os atuais. 
O desenvolvimento de acordos de compartilhamento de produtos e serviços, ao qual insere-se a atuação dos consórcios para aquisição e acesso a periódicos eletrônicos, enfrenta uma série de obstáculos intrinsecamente relacionados à globalização de mercados, no caso de publicações periódicas científicas.

Aliadas à crise das publicações impressas, as coleções digitais têm provocado uma verdadeira reengenharia no processo de desenvolvimento de coleções. A autora Saunders levanta aspectos importantes sobre a aplicação de um planejamento estratégico para tal processo e que deveriam estar sendo considerados pelos consórcios de bibliotecas. Deles, podem ser levantadas quatro grandes áreas de administração de serviços a serem desenvolvidas pelos responsáveis no gerenciamento de coleções de bibliotecas, aos quais cabem o fomento de idéias para novos projetos cooperativos (SAUNDERS, 1993: 42):

- identificação de nichos ou áreas de assuntos mais apropriadas para a aquisição de textos eletrônicos e suas conseqüentes influências para a coleção impressa existente, buscando melhor distribuir localmente e reproduzir os recursos digitais negociados;

- desenvolvimento de acordos de compartilhamento, na forma de tópicos e/ou formatos que deverão ser adquiridos e colecionados, determinando ainda quais serão emprestados ou obtidos através de pedidos de documentos;

- investimento no treinamento de pessoal, pois muitas bibliotecas já possuem sistemas de segunda e terceira geração de sistemas integrados, incluindo subsistemas de pedidos e reclamações e relatórios sofisticados de administração. A funcionalidade do sistema pode ser ampliada por um staff capaz que vê sempre novas possibilidades ao invés de recusá-las. Assim, conhecimento e flexibilidade das pessoas são críticas no desenvolvimento da biblioteca digital;

- estudo de coleções em rede versus local, sendo que, a longo prazo, tende a crescer o percentual gasto dos orçamentos de bibliotecas universitárias destinados para periódicos (atualmente em cerca de 60 a 70\%, em média, segundo a autora Saunders (1993) ), buscando uma política de aquisição e descarte que equacione os problemas com as coleções locais.

Os estudos existentes têm abordado diferentes aspectos do gerenciamento de coleções de periódicos científicos, incluindo seu boom no formato eletrônico. Podemos começar pela análise da tese de doutorado de Patrícia Marchiori, a qual polemiza duas posições existentes: a posse física, local, ou o acesso aos documentos ou informação. Acompanhando a posição de Line (1995), Marchiori aponta que o futuro das bibliotecas repousa mais na política de acesso que na política de acervo. Segundo o autor (LINE apud MARCHIORI, 1998: 52),

"apesar de existirem muitos argumentos contrários, esta política é considerada inevitável, porque muito do material informativo disponível no futuro (se não todos) estarão em formato eletrônico. Desta forma, não importará muito se o item solicitado não estiver armazenado na biblioteca, uma vez que este poderá ser facilmente obtido 
de qualquer lugar. Este posicionamento reflete uma crescente e talvez excessiva confiança no acesso remoto, assim como em um redimensionamento do papel da biblioteca que, em função de orçamentos insuficientes, tem dificuldades em manter os níveis tradicionais e desejáveis de aquisição.”.

Ainda segundo Marchiori (1998: 52 e ss.),

... nesse contexto, muito do debate que está sendo travado entre os profissionais da área relaciona-se com uma aparente dicotomia "acervo versus acesso" à informação, e boa parte do debate tem sido sobre os mecanismos de gerenciamento e desenvolvimento de coleções. As tecnologias do século XX parecem direcionar a atenção dos responsáveis pelas coleções para o conteúdo da informação que se oferece, mais que para a forma como a informação se apresenta. Os bibliotecários parecem não ter outra alternativa a não ser a de iniciar a transição para um modelo de serviço baseado no acesso, utilizando redes eletrônicas que possam oferecer informações bibliográficas, numéricas e de texto inteiro para estudiosos e pesquisadores. (....) Porém, atualmente o usuário ainda precisa, em grande parte, do acesso físico aos documentos, devendo localizá-los na biblioteca ou esperar por sua chegada, via empréstimo interbibliotecário, ou por meio de outro sistema de envio de documentos.

Esta transição nas políticas de desenvolvimento de coleções também é apontada em alguns estudos, como os de Schad (1992) e Hoadley (1993), os quais especulam que "o conceito socialmente aceito de que 'o maior é o melhor' refletiu-se no fato de as bibliotecas terem sempre sido avaliadas pelo seu tamanho físico e pelo número de exemplares". Para os autores, o tamanho tem sua relevância, mas o mais importante é a qualidade dos documentos que sustentam ou compõem o volume do acervo. As coleções das bibliotecas universitárias e de pesquisa merecem estudos mais consistentes, “... pois em muitos casos estima-se que não mais que metade dos títulos em uma biblioteca sejam usados mais que uma vez por ano". (MARCHIORI, 1998: 54)

A constatação é relevante para nossa realidade, pois tudo aponta que não as grandes, mas são as pequenas e médias bibliotecas universitárias e especializadas brasileiras que continuam a dar forte relevância para tamanho e não qualidade dos acervos. Como aponta Marchiori, citando Hoadley (1993):

a regra de Pareto $^{12}$ parece ainda aplicável às coleções bibliográficas, nas quais $20 \%$ dos títulos constantes do acervo constituem $80 \%$ do uso da coleção. Considerando que em outros estudos as conclusões têm mostrado que, quando um item do acervo é solicitado por um usuário, há uma chance em duas de o item estar emprestado. Isto pode significar que apenas um quarto da coleção da biblioteca seria usado por ano, quando mais

12 Embora MARCHIORI cite o estudo de PARETO, na realidade, esta aplicação foi feita no ambiente bibliotecário por TRUSWELL, na década de 70. 
provavelmente este índice é ainda menor. Caso se comprove a validade destas conclusões, as bibliotecas podem realmente estar com estoques excessivos e esta condição pode acabar com as bibliotecas, assim como acabou com os dinossauros.

Reforçando essa idéia, há também implicações de espaço a serem pensadas. "Estudos como os de Steele (1993), por exemplo, mostram que mesmo que as bibliotecas façam a seleção de modo extremamente cuidadoso, uma grande quantidade de livros e periódicos adquiridos são raramente ou nunca usados, principalmente de livros comprados para estudantes." (MARCHIORI, 1998: 55). Esta afirmação, embora a princípio não seja válida para algumas bibliotecas, tem certo fundo de verdade. Isto leva-nos a pensar que há algo ocorrendo há muitos anos com os processos de seleção, que menosprezam esses fatores, desvirtuando uma avaliação objetiva que considere o provável uso desses recursos - subutilizados - a médio e longo prazos.

Uma questão ainda mais importante que se coloca é se não estaríamos entrando em uma nova fase histórica na evolução das políticas de desenvolvimento de coleções: a da administração de informações digitais com a modificação das políticas de acesso. Sozinhas, tais políticas ainda não medem adequadamente quais as novas demandas criadas com 0 acesso eletrônico nas bibliotecas, dado que faltam estatísticas mais apuradas para isso - as existentes são incipientes ou não possuem um padrão de uso no universo digital, principalmente em se tratando de consórcios.

\subsubsection{Os monopólios do poder no mercado de periódicos científicos}

Um aspecto pouco abordado nos estudos sobre políticas de desenvolvimento de coleções é como as atividades dos agentes distribuidores e grandes editores e suas respectivas metas comerciais, envolvendo controle monopolístico e aumento de mercados relaciona-se com as dificuldades encontradas nas atividades de seleção e compra de periódicos científicos. Poucos são os artigos que abordam diretamente a questão. Uma exceção são os estudos de Schauder (1994) e sobretudo Meyer (1997).

Meyer aprofunda-se em suas pesquisas sobre a questão dos monopólios e busca arrolar algumas das razões para o problema do ponto de vista econômico, atrelado a questão do crescimento de custos para bibliotecas e, indiretamente, atividades consorciadas. Sem dúvida, a inflação é um sério problema pois sua taxa de crescimento excede a habilidade das bibliotecas em lidar com isto. Diversas análises foram feitas buscando solucionar este problema, como os estudos de Lewis (1989); Kingma \& Eppard (1992); e Gossen \& Irving (1995), os quais apontaram como soluções: “... subsídios federais, reclamações a fornecedores, aumento da taxa de serviços de fotocópias, convencimento de administradores 
de universidades e instituições para incremento dos orçamentos de bibliotecas, e mudança do acesso versus a posse".

Mas será a inflação e os altos custos praticados pelos agentes distribuidores o único componente dessa história de "vilões" ? Tudo indica que não. Conforme aponta Meyer em seu estudo (1997: 327), "infelizmente para bibliotecas, a demanda de usuários para qualquer que seja um dado periódico acadêmico é comumente inelástica". O autor ainda define inelasticidade como sendo,

um termo econômico que descreve a inclinação da função demanda. Em um gráfico onde o eixo vertical representa o preço e o eixo horizontal representa a quantidade, a demanda declina-se com o acréscimo quantitativo. Funções da demanda muito inelásticas são aproximadamente verticais. Como os preços sobem, a demanda oscila muito pouco. Funções da demanda altamente elásticas são próximas da linha horizontal. Muito baixo cescimento nos preços resulta em uma significante variação da demanda.

O atributo da elasticidade é muito importante então para entendermos as variações da demanda em função da oscilação de preços praticados no mercado de periódicos científicos. Seguindo o raciocínio de Meyer (1997), sobre a inelasticidade da demanda e o jogo exercido pelos detentores dos monopólios no mercado,

novas pesquisas podem confirmar que grandes editores estão hábeis para reter os monopólios do poder com as contrapartes eletrônicas de seus periódicos científicos. Um trabalho usando um modelo alternativo tem examinado a possibilidade de que grandes editores exercitam o monopólio do poder no estabelecimento de preços. A teoria prediz que em um mercado competitivo, sempre quando é caracterizada uma competição como monopolística, o preço oferecido a usuários individuais será elástico. Por substituição da medição do monopólio do poder pelo papel dos preços, tem sido mostrado que grandes editores têm alguma habilidade para influenciar os preços através da discriminação dos mesmos. (...) Havendo um aumento dos preços para indivíduos, alguns ou muitos (grifo meu) deles cancelarão suas assinaturas pagas de próprio bolso em favor do acesso eletrônico pela biblioteca. Isto é, o preço de periódicos para indivíduos é uma determinante da demanda de acesso eletrônico nas bibliotecas (Cf. CHRESSANTHIS \& CHRESSANTHIS, 1993)

Por outro lado, para analisarmos a questão dos monópolios da indústria de publicações científicas sob um espectro mais amplo - cujos atores são aqui também denominados information players, é oportuna a definição dada por Mello (1999: 173) a partir da definição de Marx (1965: 116) para monopólios : 
O movimento de concentração de capital deságua, lógica e historicamente, na centralização de capitais, o que demarca um novo patamar da luta concorrencial entre capitais individuais, agora sempre mais robustos e agigantados: sua nova fase monopolista. Tal é a lei tendencial de evolução do capitalismo. Com o monopólio, redesenha-se o mercado mundial e a geopolítica de todo o sistema global na razão direta da busca, pelo grande capital (industrial / financeiro), de novas fontes de oxigenação... (...) O monopólio é uma nova escalada do processo de concentração e centralização do capital. Por isso, não é fórmula, e sim movimento: "o monopólio produz a concorrênca, a concorrência produz o monopólio. Os monopolistas fazem entre si a concorrência, os concorrentes tornam-se monopolistas. Se os monopolistas restringem a concorrência entre si por meio de associações parciais, a concorrência aumenta entre os operários; e quanto mais a a massa dos proletários cresce em face dos monopolistas de uma nação, mais desenfreada se torna a concorrência entre os monopolistas das diferentes nações. A síntese é tal, que o monopólio apenas pode manter-se passando continuamente pela luta da concorrência"

E há ainda uma outra definição clássica a respeito das holdings operando no mercado, extraída da Encyclopédia Britannica (2002). Nela as holdings são

(...) corporações que possuem ações votantes o suficiente em uma ou mais outras empresas para exercer o controle sobre elas. Uma empresa ou corporação que existe exclusivamente com esta proposta (compra de ações de outras) é chamada de empresa holding pura, enquanto uma que também se engaja em algum ramo de negócios é chamada uma "empresa operando em holding".

Como muito bem expôs Mello (1999: 172), ao contrário do que muitos argumentam,

a concorrência econômica não é [a princípio] o contrário de uma ordem monopolista, como observa corretamente Norbert Elias. Apenas que, pela própria dinâmica contraditória do movimento de acumulação do capital, 'esta concorrência transcende seus próprios limites e se converte em seu contrário'. ${ }^{13}$

No texto, o autor deixa evidente como estão cada vez mais pautadas as relações comerciais globalizadas pela formação de grandes conglomerados monopolistas - em todos os segmentos de mercados - e a "falsa" existência de uma concorrência, que somente o é por converter-se em seu contrário e por acirrar a disputa na outra ponta das relações sociais

13 Cf. Norbert Elias, El proceso de la civilización. 2. ed. México: Fondo de cultura económica, 1993. p. 531. 
existentes: a da grande massa de trabalhadores assalariados por empregos, cada vez em menor número.

Buscando explicitar a existência desses oligopólios, os gráficos a seguir apresentam um resumo esquemático do mercado de publicações científicas atuantes no Brasil e que comercializam inclusive bases de dados bibliográficas. Por meio da leitura de relatórios financeiros anuais e parciais, da revisão de literatura, e de contatos com diversos colegas bibliotecários, foi possível colher informações que comprovam a existência de dois grandes oligopólios do poder (os information global players), atuantes também em diversos mercados espalhados pelo mundo, os quais controlam a quase totalidade do mercado local (mercado brasileiro) de produtos informacionais para bibliotecas especializadas e universitárias: o monopólio da empresa Wolters Kluwer, com sede na Holanda, e o da Thompson Corporation, com sede nos Estados Unidos. A Wolters Kluwer foi formada em 1987, pela junção da Wolters Samsom com a Kluwer, após tentativa de compra pela Elsevier, no mesmo ano, das ações da Kluwer. 


\section{Mercado de information players - parte I (grandes editores e distribuidores de bases de dados bibliográficas)}

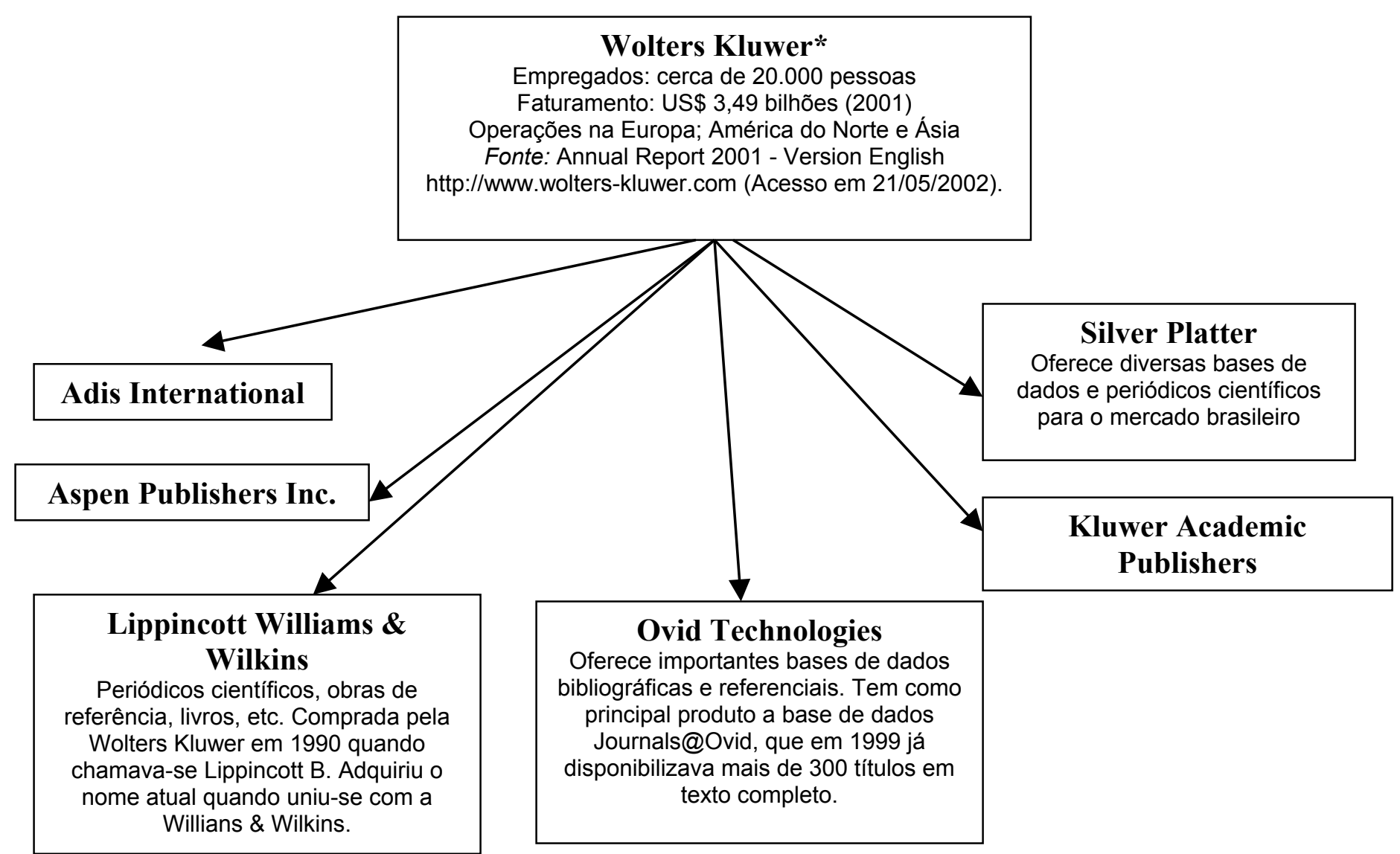

Gráfico 3: Mercado de grandes editores e empresas que comercializam periódicos científicos e outros produtos bibliográficos (bases de dados, obras de referência online, etc.) - Parte I. 
Mercado de information players - parte II

(grandes editores e distribuidores de bases de dados bibliográficas)

Thompson Corporation

Empregados: cerca de 44.000 pessoas

Faturamento: US $\$ 7.2$ bilhões

Operações em todos os continentes, com maiores escritórios no Canadá, EUA e Reino Unido.

Fonte: http://www.thomson.com/ - Acesso em 21/05/2002.

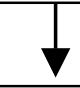

\section{Harcourt Inc.}

Através de um acordo iniciado em Outubro de 2000 e concretizado em 13.07.2001, foi comprada da Reed Elsevier NL por U\$ 2,06 bilhões. Tornou-se parte então, sem dúvida, do maior monopólio que se tem notícia no mercado mundial.

Fonte: Annual Information Report, May 17, 2001.

\section{Institute for Scientific}

\section{Information (ISI)}

Adquirida em 1992. Oferece diversas

bases de dados científicas importantes, entre elas: Web of

Science (contendo mais de 8.000 títulos de periódicos indexados em 35 línguas diferentes); Journal Citation Reports; ISI Current Contents Connects.

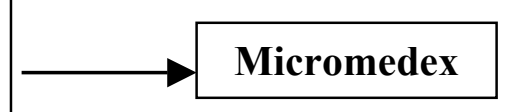

Micromedex

Tem como principal produto base de patentes Derwent World Patents Index.

Gale Group Co.

O Grupo Gale, oferecendo mais de 600 bases de dados (entre elas a interface Ingenta $\AA$ de periódicos), incorporou outras empresas editoras e voltadas para o meio acadêmico, tais como: Macmillan Reference USA, Charles Scribner's Sons, Greenhaven Press, Lucent Books, Primary Source Microfilm, Responsive Database Services e U·X·L $($.

\section{Academic Press}

Desde 1986 é parte da Harcourt Inc. Tem como principal produto a IDEAL ${ }^{\circledR}$, interface de pesquisa para a consulta de periódicos científicos.

Elsevier plc. /

Elsevier Science (subsidiária)

Embora tenha sido vendida boa parte da compania para a Thomson, ainda continua sendo uma empresa respeitável do mercado de periódicos científicos e outros produtos bibliográficos

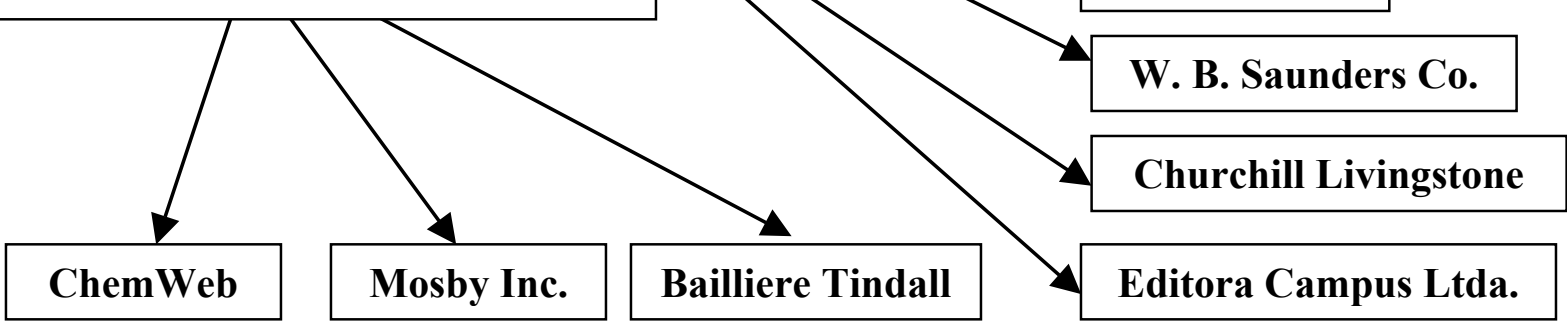

Gráfico 4: Mercado de grandes editores e empresas que comercializam periódicos científicos e outros produtos bibliográficos (bases de dados, obras de referência online, etc.) - Parte II. 


\section{Metodologia da pesquisa}

\subsection{Aspectos Conceituais}

A construção teórica desta dissertação necessariamente conduziu a uma forma de interpretação de dados, relacionada intrinsecamente com a abordagem qualitativa e influenciada por correntes de pensamento que atravessam influências advindas do marxismo dialético em sua origem ${ }^{14}$.

Tal análise interpretativa, oriunda desta construção teórica, feita em sua instância metodológica com o uso da abordagem qualitativa, fora tão fundamental quanto a própria teoria, causa-motriz da utilização de tais instrumentos. Então, fecha-se um ciclo epistemológico, através de um estudo de caso, buscando apontar para além dos dados coletados per si, atingindo assim o objetivo específico último desse estudo - e, bem provavelmente, o mais importante do ponto de vista social e bibliotecário.

Conforme aponta Lopes (1990:131-32;134), na construção de um rigoroso modelo interpretativo de dados,

...cada um dos principais métodos de interpretação nas Ciências Sociais lida com problemas teóricos próprios e com os materiais empíricos de forma diferenciada. $\mathrm{O}$ método dialético realiza o processo de abstração e generalização sempre num campo histórico, buscando as relações estruturais do fenômeno no todo social através do princípio da contradição (nível de funcionamento do tipo social histórico) (...) A questão de a pesquisa quantitativa ser descritiva e a qualitativa ser interpretativa é comumente invertida. Não são os métodos de análise que decidem o grau de elaboração teórica da pesquisa. Pelo contrário, na teorização da problemática feita desde o início da pesquisa já se delimita o grau de abstração e de generalização que se pretende alcançar. (...) A pesquisa que se define como interpretativa desde a etapa de definição do objeto já fixa em seus objetivos ir além da descrição, antecipando as operações que deverá desenvolver de acordo com o modelo teórico escolhido.

De uma certa forma, esta pesquisa tentou caminhar na direção de uma ruptura epistemológica necessária a uma ciência pós-moderna, trazendo não somente um novo conhecimento à sociedade bem como uma necessária ruptura ao senso comum. Como bem aponta Boaventura Santos (1989: 147),

... o ato epistemologicamente mais importante é a ruptura epistemológica. Isto significa que, do meu ponto de vista, deixou de ter sentido criar um conhecimento novo e autônomo em confronto com o senso comum (primeira ruptura) se esse conhecimento não se destinar a transformar o senso comum e a transformar-se nele (segunda 
ruptura). Depois de três séculos de prodigioso desenvolvimento científico, torna-se intoleravelmente alienante concluir como Wittgenstein, citado em epígrafe, que a acumulação de tanto conhecimento sobre o mundo se tenha traduzido em tão pouca sabedoria do mundo, do homem consigo próprio, com os outros, com a natureza.

A realização deste estudo teve sobretudo a crença - privilegiada pela posição do observador frente ao objeto - de que a escola da pesquisa qualitativa é a melhor alternativa metodológica no presente caso. Para tanto, no campo específico, foram utilizados no campo específico os estudos de Horn (1998) e Sutton (1993). Assim, permitiu-se elaborar o conhecimento necessário ao entendimento desse complexo campo que é o das publicações eletrônicas, suas implicações ao desenvolvimento e disseminação de suas coleções em bibliotecas e suas relações com o fenômeno da globalização eletrônica.

Mas, em realidade, a busca por um critério de análise da pesquisa que melhor se adeque aos problemas e fatores envolvidos neste objeto, optando-se pela complementaridade de métodos qualitativos e quantitativos, foi oriunda do próprio quadro teórico desta dissertação, no caso, privilegiando uma análise dialética da fundamentação teórica deste estudo. Assim, foi utilizado um método de pesquisa em que se analisou em profundidade as políticas de consórcios para desenvolvimento de coleções de periódicos eletrônicos, com o uso de um estudo de caso. Como instrumentos metodológicos deste, foram adotados: 1) a análise de documentos (ou do discurso oficial produzido pelos responsáveis pelo consórcio escolhido, e suas incongruências); 2) entrevista abertas direcionada; 3) a análise interpretativa do contexto social. O uso do estudo de caso foi particularmente útil a nosso objeto pois, como aponta Yin citado por Campomar (1991: 96),

... o estudo de casos é uma forma de se fazer pesquisa empírica ao investigar-se um fenômeno atual dentro de seu contexto de vida-real, onde as fronteiras entre o fenômeno e o contexto não são claramente definidas e na situação em que múltiplas fontes de evidência são usadas.

Devido às limitações de exeqüibilidade desta dissertação, o presente estudo abarcou um pequeno e importante grupo de bibliotecas universitárias brasileiras, tomando como ponto de referência duas perspectivas inter-relacionadas: a) a análise e observação críticas do contexto mundial e do fenômeno da globalização do mercado de periódicos científicos; b) a análise das aquisições de periódicos feitas através da atuação de um consórcio de bibliotecas, utilizando como método o estudo de caso.

14 Para um aprofundamento das questões seguindo essa linha filosófica, no campo epistemológico, é oportuno consultar a obra de Theodor Adorno, Experiência científica nos Estados Unidos. In: Consignas, Buenos Aires, Ammorrortu, 1974. 
A seleção do consórcio de bibliotecas ProBE (Programa Biblioteca Eletrônica) para este estudo de caso, dentre os poucos existentes no mercado brasileiro, foi baseada nos seguintes critérios:

1) capacidade de negociação com agentes distribuidores e/ou diretamente com os editores de periódicos eletrônicos;

2) tempo de existência do consórcio;

3) capacidade política empreendedora frente às instituições participantes do consórcio, consideradas as peculiaridades e diferenças em linhas de ação e posturas de suas lideranças;

4) visibilidade do consórcio no mercado brasileiro de periódicos eletrônicos.

Na época desta decisão pelo consórcio ProBE - meados do ano 2000, é importante ressaltar que o consórcio CAPES surgia e tinha como uma de suas principais restrições o ingresso das bibliotecas de universidades públicas paulistas. Uma das justificativas para este critério de exclusão era a contrapartida das universidades federais, que careciam assim de aporte financeiro para compra de periódicos. Tais bibliotecas eram justamente as bibliotecas-piloto detentoras dos maiores orçamentos para compra de periódicos no estado e provavelmente de toda a região sudeste brasileira. Assim, após o contexto ter se alterado meses mais tarde, havendo uma inversão de posições entre os consórcios até os dias atuais (junho de 2002), esta seleção provavelmente resultaria na escolha pelo outro consórcio.

A carênca de informações sobre projetos congêneres criou a necessidade de um levantamento dos projetos congêneres nacionais ou regionais de outros consórcios de bibliotecas na América Latina, coletando dados comparativos para se obter uma visão panorâmica de países vizinhos e com realidades mais próximas ao Brasil, os quais são descritos no capítulo 6.4.2.

Foi usado desse procedimento metodológico (o estudo de caso) pois, de outro modo, existiriam diversas dificuldades para se conduzir um estudo quantitativo ou estatístico avaliando um amplo conjunto de periódicos. Assim, ao optar por esta metodologia, a pesquisa conseguiu centrar seus esforços numa "amostra" seleta de periódicos científicos (impressos e eletrônicos) que representasse significativamente as aquisições feitas por diversas bibliotecas de universidades e institutos de pesquisa brasileiros, reunidos em um grande consórcio - 0 ProBE (Programa Biblioteca Eletrônica) - constituindo um vasto e ímpar universo, composto atualmente por cerca de centenas de milhares de periódicos científicos, internacionais e nacionais. 


\subsection{Técnicas de coleta de dados}

A coleta de dados para análise, realizada a partir do estudo de caso, contou com os seguintes instrumentos metodológicos:

a) coleta e consulta de documentos oficiais do consórcio;

b) entrevistas e questionários destinados aos principais líderes e profissionais envolvidos no consórcio escolhido, seguindo roteiro pré-elaborado e testado em um membro não participante, bem como questionários destinados aos diretores dos principais agentes distribuidores mundiais de periódicos científicos em seus escritórios no Brasil;

c) análise e relatório de atividades do consórcio, por meio das realizações de seu Comitê Gestor;

d) coleta de informações em sites oficiais dos principais agentes distribuidores participantes desse consórcio na América Latina;

e) acompanhamento de fatores ocorridos nos ambientes mundial e local (brasileiro), para posterior interpretação de dados.

Todavia, ressalta-se que essa combinação de instrumentos operacionais e métodos a utilizar é sempre uma difícil escolha que recai no pesquisador, pois, como bem observa Lopes (1990: 94) :

... isso introduz (a multiplicidade de métodos a usar) fatores de incertezas e de legitimidade. (...) Também introduz a perigosa tendência de reduzir o objeto aos níveis mais facilmente manejáveis, como ocorre com o enfoque da Sociologia ou da Psicologia Social. (...) Nesse sentido, por exemplo, Moragas entende que se deve fixar a 'bidisciplinaridade' como programa interdisciplinar concreto para a Comunicação. (...) A prática interdisciplinar (bidisciplinar ou não) estará sempre condicionada pelo paradigma eleito pelo investigador.

\subsection{Estudo de caso: o Consórcio de Bibliotecas ProBE (Programa de Biblioteca Eletrônica)}

O consórcio ProBE - Programa Biblioteca Eletrônica, conforme descreve documento produzido em seu II Workshop (PROGRAMA BIBLIOTECA ELETRÔNICA, 2001), em sua fase piloto reuniu as cinco universidades públicas paulistas (Universidade de São Paulo - USP, Universidade Estadual Paulista Júlio de Mesquita Filho - UNESP, Universidade Estadual de Campinas - UNICAMP, Universidade Federal de São Carlos - UFSCAR, Universidade Federal de São Paulo - UNIFESP) mais o Centro Latino-Americano e do Caribe de Informações em Ciências da Saúde - BIREME, visando a compra de 606 títulos de periódicos eletrônicos da 
editora Elsevier, além de pouco mais de uma dezena da HighWire Press e mais de 100 periódicos da Academic Press. O ProBE é administrado por um Comitê Gestor composto por três bibliotecários, sendo dois deles dedicados em tempo integral a suas atividades, um representante de cada membro integrante de sua formação original (USP, UNICAMP, UNESP, UNIFESP e UFSCAR), além de assessores técnicos e jurídicos.

Além das instituições que inicialmente fizeram parte de sua fase piloto, juntaram-se os institutos de pesquisa do Estado de São Paulo de diversas áreas como de saúde (Instituto Emílio Ribas, Incor, Instituto Dante Pazzanese, Instituto Adolfo Lutz, Instituo Pausteur); da Secretaria de Agricultura e Abastecimento (Instituto de Zootecnia, Instituto de Tecnologia de Alimentos, Instituto Agronômico de Campinas); Secretaria da Ciência, Tecnologia e Desenvolvimento Econômico (Instituto de Pesquisas em Engenharia Nuclear - IPEN, Instituto de Pesquisas Tecnológicas - IPT); Secretaria do Meio Ambiente (Instituto Florestal), Ministério de Ciência e Tecnologia (Instituto Nacional de Pesquisas Especiais - INPE, Laboratório de Luz Síncroton); e Ministério da Aeronáutica (Instituto de Tecnologia da Aeronáutica - ITA), entre outros, aferindo ao consórcio uma envergardura política única no país.

O consórcio cresceu aos poucos com o rápido sucesso do oferecimento do acesso ao texto completo desses títulos, e atingiu a meta de, em novembro de 2001 - segundo relatório de seu comitê gestor (RELATÓRIO PROBE, 2001), oferecer exatos 2.260 periódicos científicos eletrônicos de nove editores diferentes a uma comunidade de 145.613 pesquisadores, congregando uma rede de 132 bibliotecas de 41 instituições distintas e um orçamento global de US\$1,500,000.00 (Um milhão e quinhentos mil dólares).

Daí, coube refletir na análise de dados que se verá a seguir, sobre suas atividades e implicações políticas ao longo de sua existência - que completou 3 anos ao final de 2001 -, implicações estas muito propícias para o debate do acesso à informação: para que e para quem este se dá, mesmo considerando-se seus resultados na cadeia produtiva ? Quais os novos desafios para o gerenciamento de coleções eletrônicas ? Que ambivalências ficam explícitas em nossa tal profanada sociedade do conhecimento ?

\subsubsection{Análise e interpretação de dados}

\subsubsection{Considerações gerais}

Antes de iniciar a descrição e análise dos dados propriamente dita, é necessário tecer algumas considerações gerais. Como os instrumentos de coleta de dados e a própria construção da fundamentação teórica evidenciam, esta dissertação utiliza majoritariamente a análise e interpretação qualitativa de dados: isto justifica o fato de não serem utilizadas análises estatísticas como comprovação de proposições ou evidência de fatos, mesmo porque, no caso dos questionários aplicados, o número de respondentes foi pequeno, porém 
muito representativo de todo o universo que compõe o consórcio ProBE. Foram escolhidas as seis grandes instituições que pertenceram ao consórcio ProBE em sua fase piloto, ou seja, as principais até o final do ano 2000, que respondiam por cerca de $80 \%$ (oitenta por cento) da sustentação financeira e política do consórcio.

Então, parte da coleta de dados - a que correspondeu aos questionários e entrevista foi assim subdividida: a) os questionários destinados aos bibliotecários representantes no Comitê gestor do consórcio ProBE; b) destinados aos agentes distribuidores de periódicos científicos; e c) a entrevista semi-estruturada aplicada aos representantes do Comitê coordenador do consórcio. Todos estes instrumentos contaram com questões em sua maioria abertas, e buscando sempre a complementaridade entre si. É importante ressaltar que, do primeiro grupo (a), duas instituições deixaram de responder ao questionário, ou 33\% do total. No caso dos questionários enviados aos agentes distribuidores no país, apenas um respondeu, o que já foi considerado como satisfatório para o tipo de análise pretendida. Para todas as entrevistas e questionários feitos, foi aplicado um pré-teste visando-se aferir a terminologia, adequação e tempo real de duração da coleta, feita com um profissional da área de desenvolvimento de coleções externo ao consórcio. Embora este tipo de instrumento possa dar margem à diversas interpretações, o pré-teste indicou que os respondentes não teriam dificuldades em respondê-lo, sendo todos profissionais (diretores de instituições ou funcionários de agentes distribuidores) que estão historica e intrinsecamente envolvidos com a aquisição de periódicos científicos. Adicionalmente, foi enviada uma carta de apresentação para comentários adicionais ou perguntas ao questionário, caso fosse necessário.

Os questionários destinados aos bibliotecários membros do Comitê gestor do consórcio ProBE e aos representantes dos agentes distribuidores de periódicos científicos foram enviados por e-mail nos meses de outubro e novembro de 2001, acompanhados de uma carta de apresentação (Anexo 4), informando a natureza e os objetivos da pesquisa e ressaltando a importância desta para o estudos existentes em desenvolvimento de coleções e suas relações com um campo maior de investigações sociais. No caso da entrevista obtida com um dos representantes do Comitê coordenador do ProBE, esta foi realizada pessoalmente em meados de dezembro de 2001, auxiliada por um gravador durante um período de cerca de 2 horas.

O quadro a seguir relaciona esquematicamente os objetivos e pressupostos da pesquisa às questões aplicadas nos dois diferentes modelos de questionários e na entrevista aos membros da coordenadoria operacional do consórcio ProBE: 


\begin{tabular}{|c|c|}
\hline Objetivos e pressupostos formulados & Questões \\
\hline $\begin{array}{l}\text { Identificar as características gerais das políticas de desenvolvimento de } \\
\text { coleções adotadas pelas bibliotecas participantes do consórcio }\end{array}$ & $\begin{array}{l}\text { A01, A04, A08, } \\
\text { E04 }\end{array}$ \\
\hline $\begin{array}{l}\text { Colher dados e outros elementos que caracterizem a conjuntura sócio- } \\
\text { econômica e política - juntamente com a análise permitida pela revisão } \\
\text { da literatura, influenciando decisivamente na atividade de } \\
\text { desenvolvimento de coleções praticada pelo / através do consórcio }\end{array}$ & $\begin{array}{l}\text { A04, A05, A13, } \\
\text { E04, E13 }\end{array}$ \\
\hline $\begin{array}{l}\text { A atividade consorciada não minimiza, em última análise, as barreiras } \\
\text { para a democratização do acesso à informação, sobretudo com as } \\
\text { mudanças trazidas no mercado globalizado de periódicos científicos }\end{array}$ & $\begin{array}{l}\mathrm{A} 04, \mathrm{~A} 06, \mathrm{~A} 12, \\
\mathrm{~A} 13, \mathrm{~A} 14, \mathrm{~B} 01, \\
\mathrm{~B} 03, \mathrm{~B} 04, \mathrm{~B} 07, \\
\mathrm{~B} 08, \mathrm{E} 01, \mathrm{E} 06, \\
\mathrm{E} 07, \mathrm{E} 11\end{array}$ \\
\hline $\begin{array}{l}\text { Identificar dados e outros elementos do contexto que permitam medir a } \\
\text { capacidade empreendedora do consórcio à frente de um grupo de } \\
\text { bibliotecas selecionadas, com boa experiência em desenvolvimento de } \\
\text { coleções }\end{array}$ & $\begin{array}{l}\mathrm{A} 03, \mathrm{~A} 07, \mathrm{~A} 09, \\
\mathrm{~A} 14, \mathrm{~B} 05, \mathrm{E} 02, \\
\mathrm{E} 10, \mathrm{E} 13\end{array}$ \\
\hline $\begin{array}{l}\text { Identificar dados e outros elementos do contexto que apontem novos } \\
\text { insumos para tomada de decisões às bibliotecas participantes do } \\
\text { consórcio }\end{array}$ & $\begin{array}{l}\mathrm{A} 02, \mathrm{~A} 03, \mathrm{~A} 06, \\
\mathrm{~A} 09, \mathrm{~A} 10, \mathrm{~A} 11, \\
\mathrm{~A} 12, \mathrm{~B} 02, \mathrm{~B} 06, \\
\mathrm{E} 03, \mathrm{E} 05, \mathrm{E} 06, \\
\mathrm{E} 08, \mathrm{E} 09, \mathrm{E} 11, \\
\mathrm{E} 12\end{array}$ \\
\hline $\begin{array}{l}\text { Observação : } \\
\text { Indicação sinalética das questões referentes a cada questionário e à entre } \\
\text { Axx - Modelo I (Bibliotecários membros do comitê gestor do consórcio) } \\
\text { Bxx - Modelo II (Agentes distribuidores de periódicos) } \\
\text { Exx - Entrevista semi-estruturada (coordenadores do consórcio) }\end{array}$ & evista: \\
\hline
\end{tabular}

Quadro V: Relação entre os objetivos e pressupostos da pesquisa e questões propostas

\subsubsection{Descrição e interpretação dos resultados obtidos}

Para a descrição e interpretação dos questionários e entrevista realizados foram criadas, com o auxílio do quadro anterior, cinco categorias nominais dependentes - segundo definição dada por Júlio Cesar Pereira (2001: 44 e ss.), permitindo assim uma completa descrição e interpretação dos dados coletados. Foram então ora denominadas categorias de análise: a) políticas de desenvolvimento de coleções; b) democratização do acesso à informação científica; c) questões administrativas e novos insumos para a gerência de consórcios; d) mercado oligopolista de publicações científicas. 


\section{Parte I : Análise e discussão de questionários respondidos pelos bibliotecários membros do comitê gestor do consórcio ProBE}

A) Políticas de desenvolvimento de coleções

Conforme foi possível confirmar nas respostas dadas à questão 1, a maioria das instituições já possui uma política de desenvolvimento de coleções estruturada internamente e com um documento oficial expresso. Uma delas respondeu que este está sendo elaborado - e aqui saliento que isto ocorre até por influência das últimas mudanças no contexto da comunicação científica. Tal instituição, que ainda não tem um documento expresso, conforme foi possível levantar extra-oficialmente e em adição às informações dadas pelo questionário, já está com o documento em elaboração e deverá implementar sua política de desenvolvimento de coleções no transcorrer de 2002.

Um aspecto abordado nos questionários aplicados, com a questão 4, refere-se a qual será a tendência para a política de desenvolvimento de coleções no que tange à gerência de coleções de periódicos científicos nos próximos anos. Todas as instituições, em suas respostas, convergiram para um ponto em comum: a atividade de compartilhamento de acervos e participação cada vez maior em consórcios, buscando maximizar as coleções de cada membro participante. Uma das instituições considerou também o recurso da não duplicação de títulos para diferentes unidades daquela universidade ou de bibliotecas membros de um consórcio, enquanto outra ressaltou o fator custo / benefício das assinaturas, visando o mesmo objetivo (maximização do uso).

A questão 8 referiu-se às políticas de desenvolvimento de coleções com uma citação de Edward Shreeves (1997), comentando sobre o boom informacional e a diversidade cada vez maior de documentos disponíveis e colocando, como questão implícita, de que modo o gerenciamento de coleções vem dando conta disso. Em primeiro lugar, foi unânime a opinião de que esta atividade se tornou mais complexa, aliada ao fato de que a demanda dos usuários é cada vez maior e mais exigente. Das três instituições, apenas duas responderam como gerenciam suas coleções sob este aspecto. Uma das instituições expôs o problema do gerenciamento, apontando a necessidade de softwares cada vez mais sofisticados para auxiliar a sua equipe de trabalho nas atividades relacionadas e salientando a necessidade da qualificação profissional constante, de modo a dar conta dessa atividade. A outra instituição respondeu que o gerenciamento de coleções é uma "atividade cada vez mais difícil" e, não para minha surpresa, apontou a existência de um considerável grupo de usuários não sensíveis a adaptar-se à cultura do digital e, portanto, ainda alheio às novas tecnologias digitais de acesso ao texto completo no meio acadêmico, gerando um contrapeso para o bibliotecário, a ser considerado no momento da aquisição de periódicos eletrônicos e 
manutenção de sua contrapartida impressa. Por outro lado, a resposta apontou que permanece a questão: se estes mesmos usuários não podem se privar do formato impresso dos periódicos científicos, em que momento haverá a migração total para o periódico digital ? Ou isto não ocorrerá ?

B) Democratização do acesso à informação científica

A questão 4, em sua segunda parte, indagou se a instituição membro do consórcio, inserida num contexto de queda de receitas para aquisição de suas coleções, já implantou outras possibilidades de acesso a artigos científicos. Das três instituições, uma afirmou que a única solução encontrada foi o acesso via pedidos de envio de documentos (Ariel), enquanto outra citou a identificação e divulgação de diversos títulos de periódicos gratuitos disponíveis eletronicamente. Apenas uma das instituições realiza as duas coisas, simultaneamente.

A identificação e divulgação de títulos de periódicos disponíveis gratuitamente por meio eletrônico, aliás, é um valor agregado que supúnhamos já deveria estar presente dentro do rol de serviços ofertados em todas as instituições, dadas as adversidades na identificação de recursos existentes para a produção e comunicação científicas por pesquisadores em países periféricos como o Brasil.

Em uma das respostas à questão 6 - embora esta não seja voltada à analise desta categoria, ou seja, à democratização do acesso à informação científica -, a instituição salientou que, como os editores estão constantemente ampliando o acesso ao texto completo de seus periódicos para volumes / fascículos cada vez mais antigos, ao final de um prazo as revistas ganham mais material a ser publicado eletronicamente e isso é, indiscutivelmente, fator de facilitação para uso do periódico eletrônico, embora não necessariamente.

O fato é que, se a cultura do digital tornar-se algo predominante no meio acadêmico, isto pode vir a ser um fator decisivo contra os esforços de democratização do conhecimento para as atividades do pesquisador, muito possivelmente ampliando a manifestação do fenômeno da exclusão digital desta comunidade, por diversos fatores - e aqui apontamos como durante todo o estudo -, apenas alguns: o lobby dos monopólios, a apropriação do conhecimento pela indústria de publicações gerando a mais-valia para o pesquisador, e a constante alta dos preços de assinaturas de periódicos para as bibliotecas. Atualmente, é ainda relativamente pequena a faixa média de anos das coleções eletrônicas de periódicos científicos disponíveis.

As respostas para a questão 13 intencionaram saber das instituições do consórcio ProBE quais as outras iniciativas na América Latina visando à democratização do acesso à informação que merecem destaque. Como já era esperado, foram dadas opiniões complementares porém diferentes entre si, mostrando diversos graus de informação e 
reconhecimento de outras iniciativas. Para duas instituições, uma iniciativa que merece destaque é um projeto de esforços cooperativos de bibliotecas, envolvendo as três maiores bibliotecas de universidades públicas paulistas, denominado projeto CRUESP (Conselho de Reitores das Universidades Estaduais Paulistas). Uma destas respondentes ainda acrescenta que, tratando-se do acesso a bases de dados referenciais, o maior produto disponível é oferecido pelo CRUESP com as bases ERL - Electronic Reference Libraries (da Silver Plater), contendo um total de 40 bases de dados. Outras iniciativas citadas, cada qual com uma indicação, são o projeto SCIELO; um programa de compartilhamento do Rio de Janeiro (ainda em implantação) envolvendo bibliotecas de universidades públicas e privadas; e o portal de periódicos CAPES (acesso a textos completos), atendendo universidades públicas federais e estaduais de todo o país.

Nas respostas à questão 14 , as respondentes pautaram por destacar a possibilidade de novos projetos de consórcios destinados sobretudo para bibliotecas públicas e escolares, conforme $75 \%$ das respostas. Como bem apontou uma das instituições, "uma possibilidade seria (...) o atendimento da população em geral, tão carente de recursos para sua formação, informação e aperfeiçoamento. Poderíamos ter um compartilhamento de acervos 'eletrônicos', minimizando desta forma as diferenças entre os vários estados. Assim, a Biblioteca pública, além de seu acervo, deveria disponibilizar o acesso a esta informação, através de equipamentos que ficariam a disposição da população".

C) Questões administrativas e novos insumos para a gerência de consórcios

A questão 10 enfocou como as instituições encontram-se organizadas para a execução das atividades de desenvolvimento de coleções e as respostas foram muito próximas entre si. Para duas das três instituições, temos de dois a três bibliotecários, em média, exclusivamente dedicados à tarefa de desenvolvimento de coleções; $A$ outra instituição respondeu que conta com quatro ou mais profissionais. À exceção desta, o número é considerado razoável para a realidade brasileira, mas não chega a ser bom ou satisfatório avaliando-se os padrões internacionais, sobretudo pela crescente demanda de novos serviços.

Na resposta à questão 11, sobre quantos desses profissionais têm o domínio de softwares e ferramentas voltadas para o trabalho em rede (Internet), duas instituiçoes responderam que três funcionários atendem a esse requisito. A instituição restante respondeu que apenas dois o fazem, o que reafirma a interpretação feita para a questão anterior.

As respostas da questão 2 - sobre quais são as ferramentas para avaliação sistêmica de coleções mais utilizadas -, confirmaram as expectativas da pesquisa: duas das instituições responderam como principais fatores: custo (2 citações); fator de impacto dos periódicos científicos ( 2 citações); avaliação da comunidade e adequação ao currículo acadêmico 
(2 citações); e, em seguida, todos com uma citação: estatísticas de uso; conveniência do formato; idioma; vinculação a projetos de pesquisa em andamento. É oportuno observar que a estatística de uso - elemento muito utilizado por diversas instituições aqui e no exterior - foi citada somente por uma respondente, o que pode ser sintoma da ausência de coleta e geração contínuos de dados sobre o uso das coleções impressas.

A questão 3, visando aferir se o ProBe vem otimizando o uso de suas coleções eletrônicas e de que modo isso ocorre pelas instituições do consórcio, teve $100 \%$ das respostas afirmativas, apontando a necessidade da permanência e fortalecimento deste enquanto projeto cooperativo de compartilhamento e uso crescente de coleções digitais. A segunda parte da questão abordou em que medida tais instituições vêm implementando suas políticas de acesso. As respostas a esta parte da pergunta foram bastante diversas. Uma instituição respondeu com apenas um "sim", mas não apontou como vem fazendo tal implementação. Outra não explicitou seus mecanismos gerenciais, mas ressaltou as limitações de acesso aos textos eletrônicos: controle de acesso por IP (Internet Protocol, ou seja, o 'endereço' de um determinado computador na rede); e a terceira respondeu que tenta ampliar o número de títulos oferecidos, embora a grande limitação atual para esta instituição sejam os recursos financeiros disponíveis para pagamento de novas assinaturas. $E$ isso é um claro e fiel retrato do mercado: enquanto as verbas para bibliotecas diminuem, a demanda por novos títulos só tende a aumentar.

Outro dado ou insumo que se buscou medir está na análise da questão 6: se há a tendência ao direcionamento das pesquisas por artigos mais recentes e disponíveis em formato eletrônico. Uma das instituições não soube informar a respeito, sob a alegação de que atua como órgão supervisor de diversas bibliotecas e não tinha informações detalhadas para tal. Para outra, a resposta é que esta sempre foi uma tendência na área da saúde, porém, para outras áreas do conhecimento, isso pode não prevalecer. A terceira instituição afirma que "...até o momento, não claramente ocorra esse direcionamento (grifo meu), embora haja crescimento da demanda nessa faixa". Segundo a instituição, ainda há forte impacto pelo uso de artigos de anos anteriores para o meio acadêmico, além do que as coleções eletrônicas têm se ampliado paulatinamente. Isto confirma o fato que hoje em dia já encontramos artigos de alguns periódicos eletrônicos internacionais com até doze anos de idade.

A questão 7 buscou aferir, indiretamente, se o consórcio vem coletando sistematicamente dados estatísticos de uso das coleções eletrônicas e como é feita essa coleta de dados. Houve uma unanimidade - todas responderam que sim - demonstrando plena consciência da própria importância desta coleta de estatísticas feita pelas instituições 
participantes, as quais são regularmente enviadas pelos grandes editores e remetidos posteriormente para o comitê Coordenador do consórcio ProBE.

As respostas à questão 9 podem ser subdivididas em duas partes. Na primeira coube detectar qual o impacto das coleções eletrônicas para o empréstimo interbibliotecário e o envio de documentos. Sobre isto, as três instituições afirmaram que há uma tendência contínua, ao longo dos anos, de queda dos pedidos de empréstimos de artigos de outras bibliotecas. Mas, como ressaltou uma das instituições, parece manterem-se nos mesmos níveis os pedidos de usuários individuais. Na segunda parte da questão, foi-lhes solicitado apontar se os consórcios em geral reforçam o atendimento sob demanda e se há formas de subsidiar tais serviços ou se devem os custos serem transferidos ao pesquisador. Sobre o atendimento sob demanda, apenas duas instituições responderam e ambas disseram que sim. Confirmou-se, desta forma, uma tendência derivada da mudança de norteamento do desenvolvimento de coleções: o eixo das políticas de desenvolvimento de coleções foi redirecionado, passando da posse do documento para o acesso ao documento primário, intensificado sobretudo com o uso de coleções eletrônicas.

Sobre um possível subsídio ou custeio pelo próprio pesquisador, apenas duas instituições comentaram a questão, evidenciando, no caso, duas linhas de pensamento institucionais distintas: a primeira defende a política da informação como um bem público, mas que - sendo a própria instituição norteada por estes fins, - este subsídio deva ser cobrado em um valor mínimo que cubra os custos envolvidos, pois assim a instituição pública pode se manter e encontrar uma nova fonte de recursos; para a segunda, respondente, correspondendo ao outro perfil institucional, o subsídio pode advir diretamente do órgão de fomento - por meio do acesso ao Portal de periódicos CAPES (Campanha Nacional de Aperfeiçoamento de Ensino Superior) ou ao Portal do consórcio ProBE, por exemplo - ou indiretamente, utilizando-se as 'reservas técnicas' de pesquisa para o acesso aos periódicos, com recursos do próprio pesquisador. O que, aliás, conforme ressaltou uma das instituições que responderam esta questão, é algo polêmico, pois transfere a responsabilidade do suporte I financeiamento à pesquisa, normalmente delegada ao Estado, para as mãos do pesquisador, atuando, assim, na ponta de todo um processo de geração do conhecimento no qual o pesquisador acaba pagando literalmente pelo fruto de seu trabalho, ao ter que comprar algo (o conhecimento produzido) que ele mesmo produziu, muitas vezes a um alto custo - o das revistas científicas internacionais -, caracterizando assim um processo de mais-valia.

Logo em seguida, na questão 12, foi investigado como cada instituição cobra pelos seus serviços. O resultado é mostrado na tabela a seguir: 


\begin{tabular}{|l|l|l|l|}
\hline \multirow{2}{*}{ Serviço } & \multicolumn{2}{c|}{ Forma de cobrança } \\
\cline { 2 - 4 } & Não oferecido & \multicolumn{1}{c|}{ Pago } & \multicolumn{1}{c|}{ Gratuito } \\
\hline Fotocópias & & A B C & \\
\hline Empréstimo interbibliotecário & A & B C & \\
\hline Envio de documentos (Ariel, etc.) & & A C & B \\
\hline Download de artigos & & A C & A B C \\
\hline Empréstimo domiciliar & A & & B C \\
\hline Pesquisa em bases de dados & & C & A B C \\
\hline
\end{tabular}

Nota: As instituições respondentes encontram-se identificadas pelas iniciais A, B e C.

Tabela 2: Respostas à pergunta 12 do questionário para as bibliotecas membro do comitê gestor do consórcio ProBE

A partir da leitura da tabela anterior, cabe salientar algumas considerações :

> Para $100 \%$ das instituições respondentes, o serviço de fotocópias é pago, evidenciando que este serviço continua sendo cobrado como ocorre há vários anos. Nesse sentido, pergunta-se: não poderia o serviço ser gratuito, ao menos em parte, sobretudo para as pesquisas de pós-graduação com nível de excelência, sem qualquer cobrança direta ao usuário, por parte das bibliotecas ? ;

$>$ Dos seis serviços citados, apenas a instituição identificada nesta questão como A não oferece dois deles (o empréstimo interbibliotecário e o empréstimo domiciliar). Neste caso, fica também uma pergunta a ser respondida: será este já o prenúncio de uma tendência a ser seguida pelas outras instituições - todas elas universidades públicas paulistas ou federais ? Ou esta conjectura somente poderia ser válida no caso do empréstimo interbibliotecário, devido ao impacto do acesso ao conteúdo de periódicos científicos por meio eletrônico ? ;

$>\mathrm{Na}$ categoria de serviços gratuitos, apenas a pesquisa em bases de dados surge como comum a todas as instituições do consórcio, ainda que a instituição $C$ faça a ressalva de que este serviço possa também vir a ser cobrado, dependendo da Unidade ; Tudo aponta que cada vez mais, este serviço venha a tornar-se gratuito, até porque mesmo os grandes editores e distribuidores de periódicos científicos desenvolvem ferramentas (softwares) que estão disponíveis na Internet para pesquisas em seus respectivos serviços, envolvendo busca de artigos em diversos periódicos internacionais sem qualquer custo adicional.

$>$ O download de artigos, um dos serviços surgidos com o advento do acesso às revistas científicas em texto completo na Internet, é gratuito nas três instituições (100\%) e oferecido concomitantemente, na forma de serviço cobrado aos usuários para duas das três instituições; Aqui, cabe sempre a ressalva de que o download de um artigo é 
enganosamente isento de taxas, pois, embora o usuário não o perceba, muitos periódicos são obejtos de assinatura por parte da instituição e a liberação de acesso aos mesmos é condicionada pelo IP (Internet Protocol) do computador de onde o usuário acessa o periódico eletrônico. As únicas exceções são aqueles periódicos genuinamente gratuitos, como é o caso dos presentes no projeto SCIELO (disponíveis em http:// www.scielo.org) e poucas outras publicações internacionais, como por exemplo, o British Medical Journal.

$>$ Em contraposição, a forma da leitura do texto impresso, expressa aqui pelo serviço de empréstimo domiciliar, é oferecida pelas instituições B e C e gratuitamente, o que aponta ainda para um reflexo da permanência do hábito da leitura em papel (cultura impressa) e sua presente necessidade nas nossas grandes universidades. A questão, já aqui citada e levada ao extremo por teóricos como Pierre Lévy, é até quando essa cultura do impresso irá perdurar?

As respostas à questão 14, importantes para a gerência de projetos cooperativos / consórcios de bibliotecas, apontaram duas posturas refletindo políticas distintas: uma, mais conservadora, não acredita que um consórcio de bibliotecas pudesse contemplar outro tipo de documento que não os periódicos científicos, ou seja, ser voltado para um público altamente elitizado e que coincide com a elite social do país. As outras duas instituições responderam em um tom mais otimista e, de certo modo, com anseio mais democrático, acreditando na possibilidade de um consórcio de bibliotecas públicas e mesmo escolares. Uma delas, inclusive, citou o trabalho da Biblioteca Nacional, a qual vem "buscando alguma forma de consórcio / compartilhamento, em especial para a catalogação", ainda que isto não implique num primeiro momento no acesso ao documento.

D) Mercado oligopolista de publicações científicas

Com a questão 5 , investigou-se junto a cada instituição membro do ProBE como é constituído o mercado fornecedor de periódicos científicos, formado pelos grandes editores e agentes distribuidores. De certo modo, as respostas para esta questão foram, porém, em duas delas, admitindo a existência de cartéis ou oligopólios do poder. Uma instituição admitiu que "ainda há na América Latina um agente fornecedor que detém a maioria das assinaturas mas outros agentes já estão conseguindo se inserir no contexto latinoamericano". Esta respondente, infelizmente, afirmou não ter mais dados para poder ilustrar sua opinião. Outra instituição citou a Elsevier, a Academic Press, a Ebsco e a Swets Blackwell (note-se que ela não diferenciou uma grande editora de um agente distribuidor), afirmando, porém, desconhecer a proporção de cada uma delas no mercado. A terceira respondente destacou a Elsevier e o fato desta ter incorporado a Academic Press, além de citar explicitamente a formação de cartéis, ilustrando 
que estes se constituem até mesmo “...pela necessidade dos pequenos editores de poderem disponibilizar seus periódicos".

\section{Parte II: Análise e discussão da entrevista a um membro do Comitê Coordenador do consórcio ProBE}

A) Políticas de desenvolvimento de coleções

No item 4 da entrevista, assim como foi feito com as institituições participantes do consórcio ProBE, perguntou-se a um dos membros da gerência quais as ferramentas de avaliação de periódicos científicos consideradas como as mais importantes e se o fator de impacto continuará a ser utilizado. Para a gerência do ProBE, o fator de impacto é um forte componente na avaliação, além da demanda de uso das coleções impressas, a avaliação de uso do periódico eletrônico (atividade iniciada pelo consórcio a pouco tempo, através da estatística de uso dos mesmos). A gerência ainda acrescenta que “... de 1998 para 1999 houve um aumento muito acentuado do dólar e uma queda de orçamentos para compra, o que fez com que USP, UNICAMP, UNIFESP e UNESP fizessem uma reavaliação de seus acervos, estabelecendo títulos prioritários, menos prioritários, etc."

Isto reafirma, então, o que foi a apontado pelas instituições do consórcio como principais critérios de avaliação das revistas e não deverá se alterar a curto e médio prazos.

B) Democratização do acesso à informação científica

$\mathrm{Na}$ entrevista, a questão 1 indagou, especificamente, como a gerência enxerga a relação entre a globalização de mercados e a migração dos periódicos científicos para o formato digital na América Latina. A resposta apontada pela gerência, de como age o consórcio enquanto projeto para uma efetiva democratização do acesso à informação, - ainda que numa esfera menor (a do meio acadêmico e científico), ressalta três aspectos vitais do projeto. Segundo ela,

...a globalização trouxe maior (grifo meu) necessidade social, econômica, pois nós sabemos desse crescimento exponencial da informação, dessa valorização da informação somada ao aumento dos custos e a questão de que as instituições estão com cada vez menores orçamentos para estarem adquirindo esta informação. Então, esses três aspectos da globalização exigem o trabalho compartilhado, conjunto e distribuído, certo, para que se consiga acessar estas informações necessárias para todos. (...) Então, é a forma de se fazer uma racionalização na compra e um benefício muito grande para o profissional pesquisador na área acadêmica. 
Essa visão de mundo propiciou ao consórcio - e reside aqui, ao meu ver, seu grande mérito -, atingir boa parte de suas metas estabelecendo uma ótima interlocução de sua gerência com diferentes esferas de poder locais e sensibilizando as Universidades para a questão.

Na segunda parte da resposta dada à questão 6, a qual comentou sobre a publicação, em diários oficiais, das fusões ocorridas no mercado de publicações científicas, a gerência do ProBE faz importantes considerações a respeito da iniciativa de democratização de produção e acesso à informação científica desempenhada pelo projeto 'Open Archives' - . Conforme arrola a gerência do ProBE,

... o Open Archives não consegue fazer toda esta tramitação ${ }^{15}$, e para isto o editor necessita ter um gerente dedicado. E na área acadêmica, fazer isto, é difícil, pois o fato de um pesquisador ou professor ser editor de uma revista (gerente) não tem valor nenhum (para a área acadêmica)... Isto se torna então um sacrifício, que acaba nem constando no seu currículo como algo importante. A ABEC - Associação Brasileira de Editores Científicos - está fazendo um trabalho para que as instituições valorizem isso como um elemento da sua profissão científica, de modo que ele possa - e seja motivado - a se dedicar um pouco mais. Tudo issose deve pesar então para sabermos o que de fato vai permanecer. Temos um momento híbrido aí de transição.

O que a gerência explicita em seu depoimento, de grande importância aqui, é a desvalorização do editor enquanto atividade vital no processo de produção da informação científica. Com o Open Archives isso se alteraria e todos dessa cadeia produtiva ganhariam, sobretudo aqueles elementos que consomem a informação (o usuários), embora a gerência do consórcio acredite que este projeto, não oferecendo o cross-reference (vide nota explicativa), esteja num nível inferior ao de outros oferecendo títulos eletrônicos os quais são co-patrocinados (vendidos) pelos grandes monopólios do mercado. Não estaria a gerência do consórcio, indiretamente então, agindo de maneira indireta a favor da presença de um lobby comercial exercido pelos monópolios do poder ? Quem sai perdendo ao apoiar iniciativas como a do Open Archives ? Esta problematização demonstra algumas incongruências de projetos nacionais e regionais que podem ocorrer em atividades de compartilhamento / consórcios e sua relação com os information global players ou corporações mundiais detentores do mercado de publicações científicas.

$\mathrm{Na}$ resposta a questão 11, a respondente também teceu algumas considerações importantes sobre a responsabilidade do consórcio contemplar outro tipo de publicação e

15 O cross-reference é uma ferramenta que possibilita ao usuário mover-se hipertextualmente através de links de um artigo eletrônico para outro, independentemente de quais sejam os respectivos periódicos, mesmo sendo estes de diferentes editores internacionais. 
expandir seus propósitos para iniciativas como as de bibliotecas públicas, visando maior democratização:

... eu acho que sim, mas há aí um problema sério: as bibliotecas públicas sempre dependem do Estado, isto é, não há contrapartidas das próprias instituições, não vejo nelas uma motivação, como aliando as do estado de Minas Gerais, usando-se da FAPEMIG. Por exemplo, nos Estados Unidos, ao contrário, há diversas iniciativas como nesse sentido, como a do CICS. Não há, então, iniciativa própria, genericamente, dessas bibliotecas. As exceções são as do Rio de Janeiro que já estão se articulando nesse sentido. Outro caso digno de destaque é o da Biblioteca Nacional, que vem propondo atividades cooperativas, o que nada mais é do que parte de sua missão, dando treinamento, etc. É este o motivo do próprio projeto BIBLIODATA CALCO (desenvolvido pela Fundação Getúlio Vargas para compartilhamento de catálogos de coleções) não ter ido para frente: ele nasceu e não vingou pois surgiu em uma instituição particular e não pública, isto é, visa antes de mais nada o lucro. E o BIBLIODATA CALCO foi um projeto pioneiro, paradoxalmente.

Temos aqui uma certa contradição em seu discurso, pois, tomando-se em comparação os novos rumos do ProBE, este irá depender economicamente, também - e muito provavelmente sobretudo -, de instituições particulares, assim como ocorreu com o projeto BIBLIODATA CALCO. Mas, feita essa ressalva, sua linha de pensamento vai em concordância com a de duas instituições do consórcio ProBE, defendendo a possibilidade de extensão ou formação de um consórcio visando disponibilizar documentos eletrônicos acessíveis pela Internet às bibliotecas públicas. Cabe a questão: porque o país, enfim, carece de maior volume de consórcios regionais ? Apenas pela ineficácia de articulação política de seus membros líderes ? Ou haverá um problema estrutural de dependência ao Estado, como apontou a gerência do ProBE?

C) Questões administrativas e novos insumos para a gerência de consórcios

A questão 2 tem um interessante valor à administração de consórcios, pois extraiu um pouco da história de formação e evolução do ProBE. Perguntamos, inclusive, se este teve duas fases bem distintas nesses mais de dois anos de existência. Conforme narra a sua Coordenadoria gerencial,

... as pessoas não tinham uma percepção das vantagens de um consórcio, incluindo as bibliotecárias e os próprios dirigentes dessas instituições. Eu sempre via a dificuldade das pessoas trabalhar cooperativamente. Havia uma cultura "do que é meu" (cultura da posse), de olhar o próprio umbigo. E pelo 
próprio temor das bibliotecas de que vamos nos tornar algo a mais, um elemento externo, estranho. (...) O consórcio passou a ser solicitado pelas bibliotecas menores, pois saberiam que iriam pagar menos e ganhar muito, então para essas bibliotecas se tornou extremamente forte, saudável. A cooperação uniu as instituições, incluindo suas instâncias jurídicas. (...) E há uma consciência no Brasil, hoje em dia, de que é esse o caminho, e foi por aí que entrou a CAPES, que está procurando copiar o nosso modelo. Então, há dois principais momentos distintos: o de criação e fomento dessa cultura (do digital) e o da ampliação desse pequeno modelo do eletrônico (cultura do uso).

$\mathrm{Na}$ questão 10 , buscamos saber como as diferentes esferas de poder nacionais e órgãos de governo - por meio das políticas nacionais de informação - interagiram com o consórcio, possibilitando cooperação política, de modo a articular os diferentes atores políticos para um fim comum. A resposta indicou desarticulação e pouca sensibilidade do governo para o projeto, exceções honrosas feitas ao MEC e, principalmente, à FAPESP. Conforme salienta o membro da Coordenação do ProBE,

...da própria Sociedade da Informação não houve um reconhecimento e um estímulo e acho que porque eles se colocam numa esfera mais alta, discutindo questões de maior relevância. Pelo menos, nós não percebemos nada, o estímulo veio de baixo para cima, à exceção do $M E C$, e não o contrário. $E$, aliás, o MEC começou este apoio desde os tempos do PAP (Programa de Aquisição Planificada) para bibliotecas, nos anos de 1975, aproximadamente.

A questão 3 revelou, entre outras coisas, como é complexa, nos dias atuais, a situação de um consórcio como o ProBE no Brasil, em se tratando das dificuldades para mantê-lo enquanto atividade consorciada entre bibliotecas universitárias. A gerência é muito feliz ao ilustrar tal situação, expondo que, provavelmente,

...a CAPES vai subsididar essas instituições "guarda-chuva" (USP, UNESP, UNICAMP, UFSCAR, UNIFESP) e uma outra instituição. Pretendemos criar, então, um termo de cooperação onde essas instituições que estarão na CAPES e mantêm o programa ProBE como cooperante para estudos de subsídio da CAPES e que possa também estar assinando bases de dados e títulos que a CAPES não vai cobrir. (...) A FAPESP está se propondo a subsidiar os institutos de pesquisas (...) Se esse modelo der certo nós passaremos novamente para um consórcio, mas por enquanto vai ficar como 'cooperação institucional'. Há vários apelos das instituições particulares para entrarem no ProBE e há o fator de entrarem para o MEC. Então, usaríamos o interesse 
político dessas instituições em atingir o nível cinco de seus cursos de pósgraduação e terem seus cursos aprovados.

A resposta mostrou como há vários interesses em jogo na conjuntura atual, nesse novo contexto no âmbito nacional, os quais sem dúvida devem suplantar as então dificuldades que haviam na época de sua criação. Qualquer que seja o próximo passo dessa iniciativa, é fundamental para a atividade cooperativa um maior conhecimento do mercado eletrônico e uma articulação política cada vez maior entre os diversos participantes do consórcio (instituições, Universidades), revelando a importância desse fator externo para a gerência do mesmo, comprovando uma das hipóteses apresentadas nesta pesquisa.

A pergunta 12 da entrevista buscou levantar quais são as dificuldades e limitações atuais da comunidade de usuários para uso das coleções eletrônicas disponibilizadas pelo ProBE, na opinião de sua gerência. Ela assim se manifestou sobre o que é muito importante,

...acho que falta um marketing maior, de disseminação dos recursos existentes maior, e tinha que estar mais ativo nas instituições, dando treinamento etc., talvez porque haja um receio de que elas vão perder os seus usuários, mas isso é um ponto de interrogação para nós. Nós, a nível gerencial, fazemos todo um trabalho de divulgação e multiplicação e esperamos que os bibliotecários repassem isso tudo. $\mathrm{E}$ há dois segmentos específicos que trabalham diretamente com isso: bibliotecários de aquisição e bibliotecários de referência.

Este é um novo insumo para novas pesquisas, considerando a realidade brasileira -, o que é mais gratificante, ao revelar que agora, mais do que nunca, há uma necessidade de estreita cooperação do trabalho entre os bibliotecários de desenvolvimento de coleções e os de referência, sobretudo para aquelas instituições que atuam em consórcios. A realidade já mostra que os bibliotecários de referência, assim, precisam rever todo seu papel na disseminação do conhecimento, atuando de modo mais dinâmico, o mesmo ocorrendo com os bibliotecários de desenvolvimento de coleções. E ambos, dentro de uma instituição, precisam, mais do que nunca, "conversar entre si", pois um acervo eletrônico mal divulgado e com marketing pouco atuante gera uma perda irreparável para a atividade consorciada, uma vez que uma assinatura pode ser suspensa de um ano para o outro, sem aviso prévio ao pesquisador.

D) Mercado oligopolista de publicações científicas

E como expôs a questão 7, perguntando à gerência do consórcio se, com tudo isso, ao menos neste momento, esta acha que os oligopólios do mercado estão cada vez mais fortes, a resposta foi muito clara: “...sim, por causa desses valores agregados que as grandes 
empresas fornecedoras oferecem (o 'cross-reference' e a seleção de revistas com um alto fator de impacto atestado pelo ISI para a área acadêmica, o que é um elemento excepcional no contexto atual - casos da Wolters Kluwer, Academic Press, High Wire, Elsevier, Swets Blackwell)"

E notem então que, neste caso em específico, a gerência refere-se indiretamente, também, à Thompson Co., um dos maiores oligopólios existentes.

A questão 9 abordou o problema do comportamento dos preços de periódicos científicos e como estes têm flutuado diante da globalização deste mercado. Não confirmando as cotas de aumento dos preços de periódicos apontadas pelo agente distribuidor que respondeu ao questionário desta pesquisa, a gerência do consórcio ProBE apontou que a mesma - segundo esta um pouco mais baixa,

...é de quinze por cento, e se mantém. A negociação começou com dezessete por cento e fechamos com a taxa atual. Quando se assinava o impresso, de um ano para outro o preço se inflacionava doze por cento e hoje estamos com seis por cento somente".

Afinal, é questionável aqui também se essa taxa é exclusiva para o consórcio, e portanto verdadeira (de seis por cento), ou esta segue o padrão de inflação de preços do mercado, girando entre 10 e 15 por cento percentuais?

\section{Parte III : Análise e discussão de questionários respondidos pelos agentes distribuidores de periódicos}

A) Políticas de desenvolvimento de coleções

Para esta categoria, não coube nenhuma questão a ser analisada neste questionário aplicado aos agentes distribuidores.

B) Democratização do acesso à informação científica

A questão 1 abordou o problema do comportamento dos preços de periódicos científicos e como os agentes distribuidores mundiais têm realinhado suas políticas em função destes e da globalização deste mercado. O único agente distribuidor que ora respondeu ao questionário confirmou a alta de preços de periódicos, afirmando que “... a disponibilização do acesso eletrônico tem contribuído para a manutenção da média annual de aumento (grifo meu) dos preços, que chega a $10-12 \%$, em sua grande maioria. No entanto, temos observado o acréscimo acima da média anual, chegando alguns casos a $50 \%$ de aumento ou mais". 
Isso é um dado preocupante, pois reafirma, consequentemente, a tese de MEYER sobre a inelasticidade da demanda de uso. O agente distribuidor acrescenta, em sua resposta, a importância da versão eletrônica para a sobrevivência dos editores no mercado, “... os quais visam acrescentar a viabilização de tais títulos na Internet”.

A questão 3 colocou ao agente distribuidor, por ser ele um dos fornecedores escolhidos para vender um grande leque de publicações científicas, como este vê seu papel enquanto elemento que contribui ao processo de democratização do acesso à informação científica. Na opinião dele, ao participar de um projeto inovador e autêntico na América Latina, esta realidade é algo que "... todos teremos de nos adaptar, inclusive os editores que estarão sendo obrigados a aceitar tais negociações para manterem-se firme no mercado internacional".

Ainda que, indiretamente, o agente distribuidor em sua resposta tenha revelado uma das verdadeiras facetas desse processo global, vale dizer, os editores - assim como muitas vezes as bibliotecas, através dos consórcios -, são obrigados a aceitar as condições de negociação dessas corporações, seja pela pressão de aumento de preços dos periódicos ou pela imposição de títulos eletrônicos a serem adquiridos. Então, cabe perguntar a todos: a que democratização do conhecimento todos esses atores referem-se em seus discursos ?

Outra questão que perpassa o cerne da democratização de acesso à informação científica nessa nova ordem mundial é aquilo que denominamos a possibilidade de aumento da exclusão digital. Tratando-se de periódicos científicos eletrônicos, foi lançada a questão 7 ao agente distribuidor: qual seria na opinião dele, a tendência em relação à mudança da publicação impressa para uma cultura do digital e se o uso dos periódicos eletrônicos deveria suplantar as coleções impressas. A esse respeito, o agente distribuidor disse crer que

... a mudança é irreversível e tende a se consolidar no prazo de dez anos. Não acredito na substituição das coleções impressas por coleções eletrônicas devido ao controle de aquisição imposto pelos editores que terão de ceder a esta realidade. A realidade brasileira exige ainda mais cultivo de utilização de tal material e maior aceitação desta informação de forma eletrônica.

Esse prazo, apontado pelo agente distribuidor, é pouco razoável ? Mesmo que a realidade brasileira exija um período de maior adaptação, terá cedido à uma pressão dessa tendência mundial ? Ou, reformulando a questão, qual desses atores (editores, bibliotecas, corporações oligopolistas, agentes distribuidores de periódicos) tem maior influência política e econômica no papel de democratizar o acesso à informação científica ? Os consórcios de bibliotecas são ações que sempre estarão limitadas à realidade dos monopólios, como já há algum tempo ocorre mundo afora? 
$\mathrm{Na}$ questão 8, assim como foi a perguntado aos outros coadjuvantes neste processo às instituições do consórcio ProBE, e ao membro da Coordenação do ProBE -, procurou-se auferir a opinião do agente distribuidor sobre a possibilidade de outras formas de consórcio no Brasil, e por meio destas oferecer produtos de outro tipo (livros eletrônicos, etc.), a um custo significativamente mais baixo. Para ele, vislumbram-se poucas alternativas ao que já existe, pois

... o custo dos consórcios eletrônicos está cem por cento atrelado ao editor, que possui os direitos autorais de comercialização dos periódicos científicos. A única alternativa para uma redução de custo seria a junção de uma maior quantidade de títulos consorciados pelos interessados para que seja forçado junto aos editores melhores condições de preço.

Nossa crítica aqui à visão do agente distribuidor é se isto é um fato incontestável ou se não são as imposições do mercado que condicionam o agente distribuidor a se guiar apenas e tão somente pelo lucro, acima de tudo e de todos.

C) Questões administrativas e novos insumos para a gerência de consórcios

A questão 2 visou dimensionar junto ao agente distribuidor de periódicos qual o exato tamanho ou volume do mercado brasileiro em total de títulos eletrônicos oferecidos às bibliotecas, sobretudo após a globalização dos mercados. O respondente apontou que a empresa “... não distingue o mercado brasileiro dos demais", mas acrescentou que "... cremos que $10 \%$ das publicações disponíveis no mercado internacional já se encontram disponíveis na Web".

Se seguíssemos um raciocínio puramente matemático, considerando o total de títulos correntes disponíveis no mercado internacional segundo o ISSN International Center, que era, em 1999, de mais de 700.000 títulos, esse total estimado pelo distribuidor para periódicos eletrônicos estaria, neste ano, movendo-se em torno de 70.000 títulos, o que é um número relativamente alto, se considerarmos que as coleções disponiveis de grandes bibliotecas brasileiras dificilmente ultrapassam a casa dos 4.000 títulos de periódicos eletrônicos (entre pagos e oferecidos gratuitamente), obtidos diretamente ou através de consórcios.

A questão 5 colocou ao agente distribuidor a função de elemento crítico na avaliação dos programas de marketing e divulgação de projetos consorciados e individuais executados pelas bibliotecas, pois o que temos geralmente é o contrário (as bibliotecas os avaliando). 0 agente distribuidor afirmou que tais programas para ele são eficazes e ressaltou a importância da "... divulgação das ferramentas e material disponível para seus usuários. A atualização de tal material e conforto para seu uso pode trazer benefícios fundamentais durante um processo 
de pesquisa". Assim, o agente distribuidor reafirma a necessidade do marketing de consórcios como atividade continuamente realizada e exercida diretamente pela gerência destes, mas, sobretudo, por cada biblioteca participante da atividade cooperativa.

$\mathrm{Na}$ resposta à questão 6 , na qual se perguntou se o agente distribuidor buscará promover mudanças significativas em suas interfaces de busca e pesquisa oferecidas, as quais, em muitos casos, ultrapassam tecnologicamente as desenvolvidas e oferecidas pelas bibliotecas brasileiras, o respondente não especificou qual é seu plano de metas para os próximos anos nesse sentido, mas enfatizou que “...novos investimentos continuarão existindo para alcançarmos um ponto de excelência máxima de satisfação de nossos clientes".

Embora análises minuciosas destes softwares oferecidos pelos agentes distribuidores apontem pontos de alguma dificuldade de uso pela interface com os usuários, se considerarmos num todo aquilo que já é oferecido às biblitotecas do consórcio, estes softwares tem uma avaliação boa ou satisfatória, conforme a opinião dos principais profissionais que trabalham com desenvolvimento de coleções de instituições pertencentes ao ProBE. Mas, entretanto, os serviços de suporte às bibliotecas, no que tange ao gerenciamento das assinaturas em papel e online realizadas durante estes últimos anos, é um ponto que carece de maior investigação e análise.

D) Mercado oligopolista de publicações científicas

$\mathrm{Na}$ questão 4 foi perguntado explicitamente ao agente distribuidor qual a estratégia de atuação de sua empresa quanto às novas fusões e incorporações e como deve se comportar o mercado de periódicos científicos para a América Latina. A resposta, pela sua franqueza, surpreendeu-nos em certa medida, ao retratar mais um aspecto importante que afeta as bibliotecas. Nesse sentido, o agente distribuidor salientou:

.... vemos as fusões de assinaturas por grandes empresas como resultado de uma tentativa de reação à competitividade no mercado. Cremos que as fusões podem ser negativas do ponto de vista da competitividade, restando poucas alternativas para os clientes na escolha com quem trabalhar. Fusões geram compromissos financeiros que, consequentemente, devem ser observadas com muita cautela durante o processo de assinatura.

Tudo isso só vem a reforçar o que vem sendo exposto no transcorrer desta pesquisa, ou seja, que os monopólios de poder produzem a concorrência, a concorrência produz o monopólio. Os monopólios fazem entre si a concorrencia, daí que a concorrência não é o contrário de uma ordem monopolista, conforme expôs sabiamente em sua obra Norbert Elias (1993: 531). 


\section{Considerações finais e sugestões para estudos futuros}

A contraposição entre o discurso realizado pelas autoridades do consórcio e a praxis de sua ação política e social, além da coleta da opinião das instituições participantes e de um grande agente distribuidor, buscou aferir, sobretudo, em que medida a ação do consórcio pode influenciar o estado de coisas de um mercado de periódicos científicos controlado por oligopólios, e como o consórcio permite uma ação social e econômica, alterando ou não, o estágio em que se encontra o acesso ao conhecimento científico aos cientistas e pesquisadores de nossa sociedade, ou a esta como um todo.

Os resultados obtidos por meio do estudo de caso, com a coleta de informações por meio dos questionários enviados às instituições do consórcio ProBE e pela entrevista a sua Coordenadoria gerencial, apontaram que as bibliotecas que realizam uma atividade consorciada encontram-se em um novo patamar do desenvolvimento de coleções.

Tal constatação é corroborada pelas diversas opiniões expressas e que denotam:

$>$ a conscientização de cada instituição da importância de manterem e ampliarem o acesso compartilhado e as novas dificuldades com as quais se deparam, num contexto marcado pela crescente migração do periódico científico para o meio digital, ainda que esta não venha a ser concretizada em sua totalidade ou num prazo relativamente curto (menos de dez anos). Este fator interfere diretamente na construção e reformulação do modelo até então adotado pelas bibliotecas em suas políticas de desenvolvimento de coleções, e as quais, dependendo da política institucional ditada pela Universidade à qual a biblioteca encontra-se subordinada, tendem a facilitar o acesso ao informação científica de modo mais amplo (pela idéia da informação enquanto bem público), ou não.

> A existência de uma sadia discordância / diferenciação entre as instituições em alguns pontos de suas políticas de desenvolvimento de coleções, trazida pela atividade cooperativa do consórcio, e revelando uma possibilidade de interação política e econômica crítica das instituições enquanto elementos agentes de um processo cooperativo. Cada instituição vem buscando adaptar os seus serviços oferecidos - diversificando-os a medida do possível - à realidade criada pelo consórcio com a ampliação do acesso eletrônico a uma coleção de periódicos científicos - muitos deles de grande impacto na comunidade acadêmica. Essa modificação é uma reação das bibliotecas para manterem a sua própria sobrevivência financeira, agravada pela alta dos preços dos títulos e, consequentemente, a inelasticidade da demanda de uso.

A análise da ação do consórcio ProBE durante sua existência comprovou que ele atingiu boa parte de seus objetivos, enquanto órgão administrativo e empreendedor à frente de um grupo de bibliotecas, através de uma liderança política relativamente forte e, de certo modo, 
fundamental para a sua própria sobrevivência para os próximos anos. Embora isto ocorra, uma das ressalvas a serem feitas e comprovada por depoimentos da Coordenadoria do consórcio é a dificuldade do consórcio ProBE em repassar as suas diretrizes de execução de atividades de um marketing mais ativo, com a divulgação de todas as suas atividades aos membros consorciados, permitindo maior e mais rápida disseminação dos recursos eletrônicos existentes, tornando-as uma atividade constante nas instituições que fazem parte do mesmo.

Em relação às hipóteses apresentadas nesta pesquisa, podemos afirmar que:

$>$ em relação a primeira hipótese, conforme foi apontado pela revisão da literatura e confirmado pelos depoimentos colhidos no estudo de caso, o agravamento das dificuldades de gerenciamento das políticas de desenvolvimento de coleções de periódicos praticadas nas universidades brasileiras está intrinsecamente relacionado ao surgimento e crescimento acelerado do mercado de publicações eletrônicas. Isto se deveu a uma série de fatores que agem de maneira simultânea, como: o boom informacional da comunicação científica ampliado a uma escala geométrica pela disponibilização do acesso eletrônico aos periódicos científicos; a contínua alta ao longo dos anos de preços praticada pelos grandes oligopólios de poder - chegando a até a duas casas percentuais (entre $10 \%$ e $15 \%$ ) - os quais se tornam cada vez mais presentes no mercado de publicações científicas e oferecidas às grandes bibliotecas brasileiras; a mudança do modelo centrado na posse para o de uma política centrada no acesso ao documento primário, alterando sobremaneira a atividade profissional do bibliotecário de desenvolvimento de coleções e, principalmente, o de referência, impondo a este último a necessidade de uma revisão de seu papel e funções junto aos usuários; uma conjuntura sócio-econômica marcada pela crescente exclusão social e, paralelamente, a cobrança cada vez maior pelas bibliotecas por seus serviços, engendrando uma exclusão digital que tende a se agravar. O papel da corporação, dona de grande parte do mercado de periódicos científicos, também exerce aí uma ação direta ao limitar ao pesquisador as possibilidades de novas assinaturas, pelas suas políticas de preços.

$>$ em relação à segunda hipótese, esta comprova-se, pelo menos em parte, pelos mesmos fatores acima arrolados. Porém, cabe ressalvar que a ação do consórcio ProBE é, guardadas as devidas proporções, um exemplo de tentativa de democratização visando a ampliação do acesso ao conhecimento científico. Conforme apontou o estudo de caso, o país prescinde ou carece de um maior número de iniciativas regionais envolvendo bibliotecas de um mesmo estado ou ainda iniciativas que contemplem bibliotecas públicas que possam oferecer o acesso a diversos tipos de documentos eletrônicos - e não somente periódicos científicos - permitindo assim, a médio e longo prazos, criar-se um 
contexto informacional e sócio-econômico que viabilize uma ampla e maior democratização do acesso à informação a todos os cidadãos.

É oportuno frisar que esta pesquisa, embora tenha possibilitado o estudo da atividade de um importante consórcio de bibliotecas brasileiro e suas implicações para a democratização do acesso ao conhecimento, caracterizando boa parte de suas ações e as novas linhas de ação que se constroem nas bibliotecas em termos de políticas de desenvolvimento de coleções, não esgotou o tema proposto.

Uma das investigações importantes que necessita de maior aprofundamento é como os oligopólios de mercado de periódicos científicos agem em um mundo globalizado, e se, de fato, estes reforçam as estruturas de poder existentes. Outra investigação que pode ser considerada importante nesse novo contexto e necessita de avanços na pesquisa é como o uso das coleções eletrônicas por bibliotecas - participantes ou não de consórcios - estão alterando fortemente a atividade de bibliotecários de referência, que agora necessitam trabalhar muito mais próximos e sintonizados com a atividade de desenvolvimento de coleções. 


\section{Referências}

AFONSO, Carlos A. Internet no Brasil: o acesso para todos é possível ? São Paulo:ILDESFES (Fundação Friedrich Ebert Stiftung). Policy Paper, n. 26, set. 2000. Disponível em <http://www.fes.org.br/publi/policy paper 26.pdf>. Acesso em: 02 fev. 2001.

AMARAL, Gardel. A Internet e o compartilhamento da informação científica: o caso da Universidade de Brasília. Brasília: UnB, 1997. 145 f. Dissertação (Mestrado em Ciência da Informação - Faculdade de Esutdos Sociais Aplicados), Universidade de Brasília, Brasília.

ANDRADE, Diva; VERGUEIRO, Waldomiro de C. S. Aquisição de materiais de informação. Brasília: Briquet de Lemos, 1996. 118 p.

ATAÍDE, Maria Eliza Miranda. O lado perverso da globalização na sociedade da informação. Ciência da Informação, Brasília, v. 26, n. 3, p. 3-5, set. 1997.

ATKINSON, Ross. Managing traditional materials in an online environment: some definitions and distinctions for a future collection management. Library Resources \& Technical Services, Chicago, v. 42, n. 1, p. 7-20, 1997.

AUZA, Gonzalo Javier. Libro, cultura y revolución electrónica: una aproximación. Virtus, n. 1, mar. / abr. 1997. Disponível em:

<http://www.geocities.com/SoHo/Lofts/6132/gonzalo.htm>. Acesso em: 04 jul. 2001.

BAILEY JR.; Charles W. Scholarly electronic publishing bibliography - version 39 (October 26, 2001). Disponível em: <http://info.lib.uh.edu/sepb/sepb.html>. Acesso em: 26 out. 2001.

BALLARD, Tom. Public library networking: neat, plausible, wrong. Library Journal, North Hollywood - CA, v. 107, p. 679-683, apr. 1982.

BARRETO, Aldo de Albuquerque. Mudança estrutural no fluxo do conhecimento: a comunicação eletrônica. Ciência da Informação, Brasília, v. 27, n. 2, p. 122-127, mai. / ago. 1998.

BELL, Daniel. The end of ideology. New York: Free Press, 1960. 416 p.

BORGES, Maria Alice G. A compreensão da sociedade da informação. Ciência da Informação, Brasília, v. 29, n. 3, p. 25-32, set. / dez. 2000. 
BRAKEL, Pieter A. van. Electronic journal: publishing via Internet's WWW. Electronic Library, Bradford, v. 13, n. 4, p. 389-395, aug. 1995.

BRASIL. MINISTÉRIO DA CIÊNCIA E TECNOLOGIA. Sobre a sociedade da informação. Disponível em: <http://www.socinfo.org.br/sobre/sociedade.htm>. Acesso em: 25 out. 2000.

BRAUDEL, Fernand. A dinâmica do capitalismo. Trad. de Carlos Veiga Ferreira. 2. ed. Lisboa: Teorema, 1986.

BRYANT, Bonita. The organizational-structure of collection development. Library Resources \& Technical Services, Chicago, v. 31, n. 2, p. 111-122, apr. / june 1987.

BRZEZINSKI, Z. Between two ages: americas' role in the technetronic era. New York: Viking Press, 1969.

BUSH, VANNEVAR. As we may think. The Atlantic Monthly, v. 176, n.1, p. 101-108, july 1945.

CAMPOMAR, M. C. Do uso de "estudo de caso" em pesquisas de dissertações e teses em administração. Revista de Administração, São Paulo, v. 26, n. 3, p. 95-97, jul. / set. 1991.

CARVALHO, Isabel C. L.; KANISKI, Ana Lúcia. A sociedade do conhecimento e o acesso à informação: para que e para quem ? Ciência da Informação, Brasília, v. 29, n. 3, p. 33-39, set. / dez. 2000.

CASANOVA, Pablo González. Globalidade, neoliberalismo e democracia. In: GENTILI, Pablo (Org.). Globalização excludente: desigualdade, exclusão e democracia na nova ordem mundial. 2. ed. Petrópolis: Vozes / Laboratório de Políticas Públicas - LPP; Buenos Aires: CLACSO, 2000. p. 46-62.

CAHSE-DUNN, C. Global formation: structures of the world economy. Oxford: Basil Blackwell, 1989. Não paginado.

CASTELLS, Manuel. A era da informação: economia, sociedade e cultura. São Paulo: Paz e Terra, 1999. 2 v., v.1: A sociedade em rede, 617 p.

CHAUÍ, Marilena. Convite à filosofia. São Paulo: Ática, 1994. 440 p. 
CHURCHMAN, C. W. Introdução à teoria dos sistemas. Petrópolis: Vozes, 1971. 309 p.

CLIFT, Steven. Democracies online: building civic life on new frontier. Disponível em: <http://www.e-democracy.org/do/article.html>. Acesso em: 05 fev. 2001.

COLLINS, Mauri P.; BERGE, Zane L. IPCT journal: a case study of an electronic journal on the internet. Journal of the American Society for Information Science, vol. 45, n. 10, p. 771-776, 1994.

CHRESSANTHIS, George A.; CHRESSANTHIS, June D. Publisher monopoly power and third-degree price discrimination of scholarly journals. Technical services quarterly, v. 11, n. 2, p. 13-36, 1993.

CUNHA, Leo. Publicações científicas por meio eletrônico: critérios, cuidados, vantagens e desvantagens. Perspectivas em Ciência da Informação, Belo Horizonte, v. 2, n. 1, p. 77-92, jan. / jun. 1997.

CUNHA, Murilo Bastos da. Biblioteca digital: bibliografia internacional anotada. Ciência da Informação, Brasília, v. 26, n. 2, s. p., mai. / ago. 1997.

. Desafios na construção de uma biblioteca digital. Ciência da Informação, Brasília, v. 28, n. 3, p. 257-268, set. / dez. 1999.

. Construindo o futuro: a biblioteca universitária brasileira em 2010. Ciência da Informação, Brasília, v. 29, n. 1, p. 71-89, jan. / abr. 2000.

DICKEN, Peter. Global shift: the internationalization of economic activity. 2. ed. London: Paul Chapman Publ., 1992. 492 p.

DOSI, Giovanni et al. (Orgs.). Technical change and economic theory. London: Pinter Publishers, 1988. $646 \mathrm{p}$.

DUPAS, Gilberto. Economia global e exclusão social: pobreza, emprego, estado e o futuro do capitalismo. 2. ed. São Paulo: Paz e Terra, 2000. 241 p.

ENCYCLOPÉDIA BRITANNICA 2002. Disponível em: <http://www.britannica.com/>. Acesso em 20 abr. 2002. 
EISEN, Michael; BROWN, Pat. Should be the scientific literature particular property and controlled? Nature, Section Webdebates, 15 may 2001. Disponível em: $<$ http://www.nature.com/nature/debates/e-access/Articles/Eisen.htm>. Acesso em: 22 jul. 2001.

EVANS, G. Edward. Developing library and information center collections. 3rd. ed. Littleton: Libraries Unlimited, 1995. 642 p.

EWING, M. Keith; HAUPTMANN, Robert. Is tradicional reference service obsolete ? Journal of Academic Librarianship, vol. 21, p. 3-6. 1995.

FECKO, Mary Beth; LANGSCHIED, Linda. The impact of electronic journals on traditional library services. Serials Librarian, n. 21, p. 185-187, 1991.

FENG, Y. T. The necessity for a collection development policy statement. Library Resources \& Technical Services, Chicago, v. 23, n. 1, p. 39-44, 1979.

FURTADO, Celso. O capitalismo global. São Paulo: Paz e Terra, 1998. 81 p.

GUÉHENNO, Jean Marie. La fin de la démocratie. Paris: Flammarion, 1993.170p.

GWINN, N. E.; MOSHER, P. Coordinating collection development: the RLG Conspectus. College and Research Libraries, Annapolis Junction, v. 44, n. 2, p. 128-140, 1983.

HACKEN, Richard. RLG Conoco study and its aftermarth: is resource sharing in limbo ? Journal of Academic Librarianship, v. 18, p. 21-22, mar. 1992.

HARLOE, Bart (Ed.). Guide to Cooperative Collection Development. Chicago: American Library Association, 1994. 48 p. (ALCTS Collection Management and Development Guides, 6).

HARTER, Stephen P. Scholarly communication and the digital library: problems and issues. Journal of Digital Information, v. 1, n. 1, Abr. 1997. Disponível em: <http://jodi.ecs.soton.ac.uk/Articles/v01/i01/Harter/>. Acesso em: 22 fev. 1999.

HARRISON, Teresa M.; STEPHEN, Timothy D. The Electronic Journal as the Heart of an Online Scholarly Community. Library Trends, vol. 43, p. 592-608, spring 1995. 
HIREMATH, Uma. Electronic consortia: resource sharing in the digital age. Collection Building, v. 20, n. 2, p. 80-87, 2001.

HIRST, Paul; THOMPSON, Grahame. The problem of globalization: international economic relations, national economic management and formation of trading blocks. Economy and Society, v. 21, n. 4, p. 357-96, nov. 1992.

Globalização em questão: a economia internacional e as possibilidades de governabilidade. São Paulo: Vozes, 1998. 364 p.

HITCHCOCK, Steve (Org.). Web journals publishing: a UK perspective. Serials, v. 10, n. 3, p. 285-299, nov. 1997. Disponível em: <http://journals.ecs.soton.ac.uk/uksg.htm>. Acesso em 06 ago.1999.

HOADLEY, Irene. Access versus ownership: myth or reality. Library Acquisitions: practice and theory, v. 17, n. 2, p. 191-195, summer 1993.

HORN, Jim. Qualitative research literature: a bibliographic essay. Library Trends, v. 46, n. 4, p. 602-615, spring 1998.

IANNI, Octavio. Teorias da globalização. 8. ed. Rio de Janeiro: Civilização Brasileira, 2000. 228 p.

A sociedade global. 2. ed. Rio de Janeiro: Civilização Brasileira, 1993. $194 \mathrm{p}$.

INTERNATIONAL COALITION OF LIBRARY CONSORTIA. International coalition of library consortia expresses concern about information industry merger. may 2001. Disponível em: <http://www.library.yale.edu/consortia/kluwer.html>. Acesso em 22/10/2001.

INSTITUTO DE PESQUISA ECONÔMICA APLICADA. Relatório sobre o desenvolvimento humano no brasil. Brasília: IPEA; PNUD, 1996.185 p.

JIMÉNEZ, Elsi. La puerta esta abierta para los consorcios de unidades de información en America Latina y el Caribe. In: SIMPOSIO VIRTUAL DE INFORMACIÓN COOPERACIÓN ENTRE UNIDADES DE INFORMACIÓN: CONSORCIOS, 1., 2001, Venezuela. Anais... Disponível em:

< http://biblio.ivic.ve/simposios/consorcios/trabajos/html/jim01.html>. Acesso em: 29 jan. 2001. 
KHOURI, Anastassia. The digital challenges to collections: duality, complementarity and sharing. IINFO'97 - CONGRESSO INTERNATIONAL DE INFORMACION, 1997, Havana. Anais... Disponível em: <http://vm1.mcgill.ca/ adsa/http/conf/cuba.htm>. Acesso em: 25 fev.1999.

KINGMA, Bruce; EPPARD, Philip. Journal price escalation and the market for information: the librarians' solution. College and research libraries, Annapolis Junction, v. 53, n. 6, p. 523-535, Nov. 1992.

KLAES, Rejane Raffo. Dados e informações usados na tomada de decisão em bibliotecas universitárias brasileiras: o contexto da atividade de desenvolvimento de coleções. Brasília, 1991. 271 f. Dissertação (Mestrado em Biblioteconomia) - Faculdade de Estudos Sociais Aplicados, Universidade de Brasília, Brasília.

LASHER, Rebecca; VICKY, Reich; ANDERSON, Greg. The Computer science technical report (CS-TR) project: considerations from the library perspective. Califórnia : Stanford University/ Dept. of Computer Science, 1995. 28 p. Disponível em:

<http://elib.stanford.edu/Dienst/Repository/2.0/Body/stanford.cs\%2fCS-TR-95-1554/pdf>. Acesso em: 15 mar. 2001.

LÉVY, Pierre. A inteligência coletiva: por uma antropologia do ciberespaço. São Paulo: Ed. Loyola, 1998. 212 p.

Cibercultura. São Paulo: Ed. 34, 1999. 264 p.

LINE, Maurice. Access versus ownership: how real an alternative is it ? In: GENERAL CONFERENCE OF INTERNATIONAL FEDERATION OF LIBRARY ASSOCIATIONS , 61. 1995, Istambul. Anais... p. 18-28 (booklet 1).

LOPES, Maria Immacolata Vassalo. Pesquisa em comunicação: formulação de um modelo metodológico. São Paulo: Ed. Loyola, 1990. 148 p.

MACHOVEC, George. Eletronic journal market overview - 1997. Denver: Colorado Alliance of Research Libraries, mar. 1997. Disponível em:

<http://www.coalliance.org/reports/ejournal.htm>. Acesso em: 23 ago. 2000.

MARCHIORI, Patricia Zeni. Do acervo ao acesso: a perspectiva da biblioteca virtual e a atuação do intermediário de informação no contexto das atividades de Pesquisa \& 
Desenvolvimento em empresas industriais do estado de São Paulo. São Paulo, 1998. 293 f. Tese (Doutorado em Ciências da Informação e Documentação) - Escola de Comunicações e Artes, Unibersidade de São Paulo, São Paulo.

MARX, Karl. Misére de la philosophie. In: Oeuvres - économie. Paris: Gallimard, 1965.

MASON, R. O. The value of information. In: Intellectual foundations for information professionals. New York: Columbia University Press, 1987. p. 64

MATTELART, Armand, e Michèle. História das teorias da comunicação. Trad. de Luiz Paulo Rouanet. São Paulo: Ed. Loyola, 1999. 220 p.

McLUHAN, Marshall. Os meios de comunicação como extensões do homem. 4. ed. São Paulo: Cultrix, 1974. 407 p.

A galáxia de Gutenberg. São Paulo: Nacional, 1977. 390 p.

MEADOWS, A. J. (Ed.). The scientific journal. London: Aslib, 1979. 300 p. (Aslib Reader Series, 2).

MELLO, Alex Fiuza de. Marx e a globalização. São Paulo: Boitempo, 1999. 286 p.

MEYER, Richard W. Monopoly power and electronic journals. Library Quarterly, v. 67, n. 4, p. 325-349, 1997.

MIRANDA, Antonio Lisboa C. de. Acesso ao documento primário: um estudo comparado dos modelos centralizados, semidescentralizados e descentralizados de sistemas e servicos interbibliotecarios. São Paulo, 1987. 276 f.Tese (Doutorado em Ciências da Informação e Documentação) - Escola de Comunicações e Artes, Universidade de São Paulo, Sào Paulo.

NEDER, Cristiane $P$. As influências das novas tecnologias de comunicação social na formação política. São Paulo, 2001. 210 f. Dissertação (Mestrado em Ciências da Informação e Documentação) - Escola de Comunicações e Artes, Universidade de São Paulo, São Paulo.

NOGUEIRA, César; VARGAS, Nilson. A radiografia da internet brasileira. Veja, São Paulo, n. 1672,25 out. 2000. Disponível em:

<http://www2.uol.com.br/veja/251000/p 136.html>. Acesso em: 25 out. 2001. 
NORA, Simon; MINC, Alain. A informatização da sociedade. Lisboa: Europa-América, 1981. 244 p.

ODLYZKO, Andrew. The economics of electronic journal. First Monday, v. 2, n.8, aug.1997. Disponível em:

<http://firstmonday.org/issues/issue2_8/odlyzko/index.html>. Acesso em: 06 fev. 2001.

OLSEN, Jan. Electronic journal literature :implications for scholars. Westport : Mecklermedia, 1994. 78 p.

ORTIZ, Renato. Mundialização e cultura. São Paulo: Record, 1994. 234 p.

Identidades culturais no contexto da globalização. Comunicação \& Educação, São Paulo, v. 6, n.18, p. 68-80, mai./ago. 2000.

PAYNE, Lizanne. A digital library in a virtual enterprise. In: Libraries as leaders: integrating systems for service. OCLC Symposium at ALA Midwinter. February 14, 1997. Video tapes. No. $1 / 2$.

PEARLSTEIN, Steven. Canadá receia virar $51^{\circ}$ estado americano. Estado de São Paulo, São Paulo, 10 set. 2000, p. A-14.

PEREIRA, Júlio Cesar R. Análise de dados qualitativos: estratégias metodológicas para as ciências da saúde, humanas e sociais. 3. ed. São Paulo: EDUSP, 2001. 154 p.

PORAT, Marc. The information economy: definition and measurement. Washington, DC: US Department of Commerce, Office of Telecommunications. Publicação, $\quad$ 77-12 (1), 1977.

PUBLIC LIBRARY OF SCIENCE. 2002. Disponível em : <http://www.publiclibraryofscience.org>. Acesso em 30 mai. 2002.

PROGRAMA BIBLIOTECA ELETRÔNICA. Relatório ProBe. São Paulo: ProBE, 01 mar. 2001. Disponível em: <http://www.probe.br/probe-hist.htm>. Acesso em: 10 mar.2001.

REIS, Elisa P. Percepções da elite sobre pobreza e desigualdade. Revista Brasileira de Ciências Sociais, São Paulo, v. 15, n. 42, p. 143-152, fev. 2000. 
RODGERS, Garry; GORE, Charles; FIGUEIREDO, José (Orgs). Social exclusion: rethoric, reality, responses. Geneva: International Institute for Labor Studies, 1995. 310 p.

ROGERS, S.; HURT, C. S. How scholarly communication should work in the 21st century. College and Research Libraries, Annapolis Junction, v. 51, n. 1, p. 5-8, jan. 1990

SANTOS, Boaventura de Souza. Introdução a uma ciência pós-moderna. Rio de Janeiro: Graal, 1989. 176 p.

SANTOS, Milton. Técnica, espaço, tempo: globalização e meio técnico-científico informacional. 4. ed. São Paulo: Hucitec, 1998. 190 p.

SAUNDERS, Laverna M. Transforming acquisitions to support virtual libraries. Information Technology and Libraries, vol. 14, n. 1, p. 42-43, mar. 1993.

SCHAD, Jasper $G$. The future of collection development in era of fiscal stringency: a symposium. Journal of Academic Librarianship, v. 18, n. 1, p. 4-7, mar. 1992.

SCHAFF, Adam. A sociedade informática: as conseqüências sociais da segunda revolução industrial. 2a. ed. São Paulo: Ed. da UNESP / Brasiliense, 1991.160 p.

SCHAUDER, Don. Electronic Publishing of Professional Articles: Attitudes of Academics and Implications for the Scholarly Communication Industry. Journal of the American Society for Information Science, n. 45, p. 73-100, mar. 1994.

SCHERER-WARREN, Ilse. Redes e sociedade civil global. In: Seminário de estudos sobre as organizações nao governamentais na América Latina: situação e perspectivas. São Paulo: PUC-SP; ABONG; Asociacion Latinoamericana de Organizaciones de Promocion - ALOP. Dezembro de 2001. 17 p.

SHREEVES, Edward. Is there a future for cooperative collection development in the digital age ? Library Trends, v. 45, n. 3, p. 373-390, winter 1997.

SILVEIRA, Sérgio Amadeu da. Exclusão digital: a miséria na era da informação. São Paulo: Fund. Perseu Abramo, 2001. 47 p.

STEELE, Collin. Millennial libraries: management changes in an electronic environment. The Electronic Libraries, v. 84, n.4, p. 202-205, fall 1993. 
SUTTON, Brett. The rationale for qualitative research: a review of principles and theoretical foundations. Library Quarterly, v. 63, n. 4, p. 411-430. 1993.

SWETS BLACKWELL. Swets Blackwell to acquire Martinus Nijhoff International. 09/08/2001. Disponível em:<http://www.swetsblackwell.com/press.htm>. Acesso em: 11 jan. 2002.

TEIXEIRA COELHO, José. Dicionário crítico de política cultural: cultura e imaginário. São Paulo: Iluminuras, 1997. 383 p.

UNIVERSIDADE FEDERAL DO PARÁ. BIBLIOTECA CENTRAL. DIVISÃO DE INFORMAÇÃO. Consórcio nacional de periódicos eletrônicos. Disponível em: http://www.ufpa.br/bc/consorcio periodicos eletronicos.htm>. Acesso em: 28 jan. 2001.

VATTIMO, Gianni. A sociedade transparente. Lisboa: Relógio d'água, 1992. $82 \mathrm{p}$

VERGUEIRO, Waldomiro de Castro S. Estabelecimento de políticas para o desenvolvimento de coleções. Revista de Biblioteconomia de Brasília, v. 15, n. 2, p. 193201, jul. / dez. 1987.

Bibliotecas públicas e mudança social: a contribuição do desenvolvimento de coleções. São Paulo, 1990. 242 f. Tese (Doutorado em Ciências da Informação e Documentação) - Escola de Comunicações e Artes, Universidade de São Paulo, São Paulo.

VIRILIO, Paul. A arte do motor. São Paulo: Estação Liberdade, 1996. 134 p.

WALLERSTEIN, Immanuel. EI moderno sistema mundial: la agricultura capitalista y los origes de la economia-mundo europea en siglo XVI, vol. I. México: Siglo Veintiuno Editores, 1979.

The politics of the world-economy: the states, the movements and the civilizations. Cambridge: Cambridge University Press, 1988. 


\section{Bibliografia Complementar}

AGUIAR, Sonia. Observatório da cidadania: monitorando as políticas públicas em âmbito global. Ciência da Informação, Brasília, v. 28, n. 2., Maio 1999.

AINSWORTH, Shirley. Necesidades y posibilidades: la construcción de una biblioteca electrónica. In: SEMINARIO INTERNACIONAL SOBRE DESARROLLO DE COLECCIONES, 1., nov. 1997. Anais... Disponível em: <http://www.ibt.unam.mx/paginas/shirley/cuib.htm>. Acesso em: 02 fev. 2000.

AWCC 1999 CONFERENCE. Creating new strategies for cooperative collection development. [Draft, 27 November 1999]. 3 p.

BAGGIO, Roberto. A sociedade da informação e a infoexclusão. Ciência da Informação, Brasília, v. 29, n. 2, p. 16-21, maio / ago. 2000.

BAUMAN, Zygmunt. Globalização: as conseqüências humanas. Rio de Janeiro: Zahar, 1999. $145 \mathrm{p}$.

BELFIORE-WANDERLEY, Mariangela; BÓGUS, Lucia; YAZBEK, Maria Carmelita (orgs.) Desigualdade e a questão social. São Paulo: EDUC, 2000. 272 p.

BOURDIEU, Pierre. El oficio del sociólogo. México: Siglo XXI, 1994. 371 p.

BROWN, Gary. La revista eletrónica: los desafios de autores, lectores y editoriales. In: CETTO, Ana Maria; ALONSO, Octavio (Orgs.). Revistas científicas en América Latina. México: Fondo de Cultura Económica, 1999. p. 40-49.

CARVALHO, M. C. R.; KLAES, Rejane. Desenvolvimento de coleções em bibliotecas universitárias: proposta de metodologias e estatísticas. In: SEMINÁRIO NACIONAL DE BIBLIOTECAS UNIVERSITÁRIAS, 7., 1991, Rio de Janeiro. Anais....Rio de Janeiro: s.d.,1991. v.1.

CASTELLS, Manuel. A era da informação: economia, sociedade e cultura. São Paulo: Paz e Terra, 1999. 2 v., v.2: O poder da identidade, 530 p.

COLLECTION DEVELOPMENT COMMITTEE. AMERICAN LIBRARY ASSOCIATION. Guidelines for the formulation of collection policies. Library Resources \& Technical Services, Chicago, v. 21, n. 1, p. 41-46, 1977. 
CRAWFORD, Walt, GORMAN, Michael. Future libraries: dreams, madness and reality. Chicago: American Library Association, 1995. 198 p.

DEMAS, Samuel. Collection development for the electronic library: a conceptual and organizational model. Library Hi Tech, v. 12, n. 3, p. 71-80, 1994.

DEMAS, Samuel; McDONALD, Peter; LAWRENCE Gregory. The Internet and collection development: mainstreaming selection of Internet resources. Library Resources \& Technical Services, Chicago, v. 39, n. 3, p. 275 -290, feb. 1995.

DEMO, Pedro. Ambivalências da sociedade da informação. Ciência da Informação, v. 29, n. 2, p. 37-2, maio /Ago. 2000.

FELDMANN, Paulo Roberto. Exclusão digital. Folha de São Paulo. São Paulo, 07 fev. 2001. Caderno Opinião, p. A-3.

FREITAS, Christiane Soares de. Ciência na Internet: novas práticas e relações no campo científico. Brasília, 1998. 134 f. Dissertação (Mestrado em - Faculdade de Estudos Sociais Aplicados, Universidade de Brasília, Brasília.

FUTAS, Elizabeth. Library acquisitions: policies and procedures. Phoenix, Arizona: Oryx Press, 1984. 579 p.

GENTILI, Pablo (Org.). Globalização excludente: desigualdade, exclusão e democracia na nova ordem mundial. 2a. ed. Petrópolis: Vozes / Laboratório de Políticas Públicas - LPP; Buenos Aires: CLACSO, 2000. 251 p.

GORMAN, G. E.; MILLER, R. H. (Eds.). Collection management for the 21st century: a handbook for librarians. London: Greenwood Press, [200?].

HAGUETTE, Teresa Maria Frota. Metodologias qualitativas na sociologia. 3. ed. Petrópolis: Vozes, 1992. 224 p.

INTERNATIONAL COALITION OF LIBRARY CONSORTIA. Guidelines for technical issues in request for proposal (RFP) requirements and contract negotiations. Jan., 1999. $7 \mathrm{p}$.

JASMÉN S., Anita María. Alerta al conocimiento s.a.: consorcio de bibliotecas en Chile. Transinformação, Campinas, n. 10, p. 1, jan./abril 1998. Disponível em: 
$<$ http://www.puccamp.br/ biblio/transinformacao/old/vol10n1/pag62.htmlls. Acesso em: 19 set. 2000.

JAYARO, Xiomara. El proceso cooperativo de aquisición de publicaciones seriadas: una propuesta para estructurar un consorcio en unidades de información académicas y de investigación en Venezuela. In: SIMPOSIO VIRTUAL DE INFORMACIÓN COOPERACIÓN ENTRE UNIDADES DE INFORMACIÓN: CONSORCIOS, 1., 2001, Venezuela. Anais... Disponível em:

<http://biblio.ivic.ve/simposios/consorcios/trabajos/html/xio01.htmll>. Acesso em: 29 jan. 2001.

JOHNSON, Steven. Cultura da Interface. Rio de Janeiro: Zahar, 2000. 189 p.

KOPP, James J. Chapter six: the politics of virtual collection. Collection Management, v. 22, n. 1/2, p. 81-100, 1997.

LASTRES, Helena M. M.; ALBAGLI, Arita. Informação e globalização na era do conhecimento. São Paulo: Campus, 1999. 318 p.

LEE, Sul H. Library material costs and access to information. New York: Haworth Press, 1990. 114 p.

LEHER, Roberto. Da ideologia do desenvolvimento à ideologia da globalização : a educação como estratégia do Banco Mundial para alívio da pobreza. São Paulo, 1998. 267 f. Tese (Doutorado) - Faculdade de Educação, Universidade de São Paulo, São Paulo.

LÉVY, Pierre. A virtualização do texto. In: O que é o virtual ? São Paulo: Ed. 34, 1996. p. 35-59.

LYON, DAVID. The information society: issues and ilusions. Cambridge: Polity Press, 1988.

LYNCH, Clifford. Searching the Internet. Scientific American, v. 276, n. 3, p. 52-56, mar. 1997.

MAGRILL, Rose Mary. Acquisitions management and collection development in libraries. 2. ed. Chicago: American Library Association, 1989. 285 p. 
McELROY, Emily. Management of e-journals survey. Chicago: Loyola University Health Sciences Library, 2001. 67 p. Disponível em:

<http://www.formsite.com/ABCD/journalmanagement/>. Acesso em: 08 maio 2001.

MIRANDA, Antonio Lisboa C. de Globalización y sistemas de información: nuevos paradigmas y nuevos desafíos. In: La educación superior en el siglo XXI: visión de América Latina y el Caribe. Caracas: UNESCO/CRESALC, 1997.

(necessita verificar)

MORAGAS SPA, Miquel. Ubicación epistemológica e ideológica de la comunicación de masas. In: CHRISTLIEB, F. F.; HERNÁNDEZ, M. Y. (Orgs.). Comunicación y teoria social. México: UNAM/Facultad de Ciencias Políticas y Sociales, 1984.

NEAL, James G. Chaos breeds life: finding opportunities for library advancement during a period of collection schziophrenia. Journal of Library Administration, v. 28, n. 1, p. 3-32, 1999.

NIELSEN, Jacob. Hypermedia and hypertext: the Internet and beyond. Boston: Academic Press, 1990. 263 p.

NORMAN, O. Gene. The impact of electronic information sources on collection development: a survey of current practice. Library Hi Tech, v. 57/58, n. 1/2, p. 123-132. 1997.

ODLYZKO, Andrew. Compettion and cooperation: libraries and publishers in the transition to electronic scholarly journals. Versão revisada, april 27, 1999. Disponível em: $<$ http://www.research.att.com/ amo/doc/competition.cooperation.pdf>. Acesso em: 06 fev. 2001.

PISTICELLI, Alejandro. Ciberculturas. Buenos Aires: Paidós, 1995.

QUÉAU, Philippe. A revolução da informação: em busca do bem comum. Ciência da Informação, Brasília, v. 27, n. 2, p.198-205, mai. / ago. 1998.

SCHERER-WARREN, Ilse. Cidadania sem fronteiras: ações coletivas na era da globalização. São Paulo: Hucitec, 1999. Não paginado.

SCHWARTZ, Gilson. Exclusão digital entra na agenda econômica mundial. Folha de São Paulo, São Paulo, 18 jan. 2000. 
SFEZ, Lucien. Crítica da comunicação. São Paulo: Loyola, 1994. 389 p.

SHREEVES, Edward. Between the visionaries and the luddites: collection development and electronic resources in the humanities. Library Trends, v. 40, n. 4, p. 579-595, spring 1992.

VERGUEIRO, Waldomiro de Castro S. O futuro das bibliotecas e o desenvolvimento de coleções: perspectivas de atuação para uma realidade em efervescência. Perspectivas em Ciência da Informação, Belo Horizonte, v. 2, n. 1, p. 93-107, jan. / jun. 1997.

VIEIRA, Liszt. Cidadania e globalização. 4. ed. Rio de Janeiro: Record, 2000. 142 p.

VILCHES, Lorenzo. Globalização, mídia e cultura contemporânea. Campo Grande: Letra livre, 1997. 262 p.

VIRILIO, Paul. A bomba informática. São Paulo: Estação Liberdade, 1999. 142 p.

WHITE, Gary W.; CRAWFORD, Gregory A. Developing an electronic information resources collection development policy. Collection Building, v. 16, n. 2, p. 53-57, 1997.

WOODWARD, Hazel; MEADOWS, Jack; McKNIGHT, Cliff; ROWLAND, Fytton et alii. Café jus: an electronic journals user survey. Journal of Digital Information, v. 1, n. 3, oct. 1998. 
ANEXOS 


\section{TERMO DE INSTITUIÇÃO DO CONSÓRCIO DE COOPERAÇÃO INSTITUCIONAL TERMO DE INSTITUIÇÃO DE CONSÓRCIO DE COOPERAÇÃO INSTITUCIONAL}

Termo de Instituição de Consórcio que entre si celebram a FAPESP, a USP, a UNICAMP, a UNESP, a UFSCar, a UNIFESP e a OPS/BIREME.

Pelo presente instrumento administrativo de Termo de Instituição de Consórcio, as partes, a FUNDAÇÃO DE AMPARO À PESQUISA DO ESTADO DE SÃO PAULO, com sede à Rua Pio XI, no 1.500, São Paulo - SP, inscrita no CGC-MF sob o $n^{\circ} 43.828 .151 / 0001-45$, neste ato representada pelo seu Presidente, Prof. Dr. CARLOS HENRIQUE DE BRITO CRUZ, doravante denominada FAPESP; a UNIVERSIDADE DE SÃO PAULO, com sede à Rua da Reitoria $n^{\circ}$ 109, São Paulo - SP, inscrita no CGCMF sob o no 63.025.530/0001-04, neste ato representada por seu Reitor, Prof. Dr. JACQUES MARCOVITCH, doravante denominada USP; a UNIVERSIDADE ESTADUAL DE CAMPINAS, com sede à Cidade Universitária "Zeferino Vaz" , Campinas - SP, inscrita no CGC-MF sob o nํㅜ 46.068.425/000133, neste ato representada por seu Reitor, Prof. Dr. HERMANO DE MEDEIROS FERREIRA TAVARES, doravante denominada UNICAMP; a UNIVERSIDADE ESTADUAL PAULISTA JULIO DE MESQUITA FILHO, com sede à Alameda Santos, 647, São Paulo - SP, inscrita no CGC-MF sob o no 48.031.918/0001-24, neste ato representada por seu Reitor, Prof. Dr. ANTONIO MANOEL DOS SANTOS SILVA, doravante denominada UNESP; a UNIVERSIDADE FEDERAL DE SÃO CARLOS, com sede à Rodovia Washington Luiz, Km. 235, no Município de São Carlos - São Paulo, inscrita no CGC-MF sob o no 45.358.058/0001-40, neste ato representada por seu Reitor, Prof. Dr. JOSÉ RUBENS REBELATTO, doravante denominada UFSCar; a UNIVERSIDADE FEDERAL DE SÃO PAULO, com sede à Rua Botucatu, 740 - São Paulo - SP, inscrita no CGC-MF sob o n 60.453.032/0001-74, neste ato representada por seu Reitor, Prof. Dr. HÉLIO EGYDIO NOGUEIRA, doravante denominada UNIFESP; e a ORGANIZAÇÃO PANAMERICANA DA SAÚDE/ORGANIZAÇÃO MUNDIAL DA SAÚDE (OPS/OMS), através do CENTRO LATINO AMERICANO E DO CARIBE PARA INFORMAÇÃO EM CIÊNCIAS DA SAÚDE (BIREME), com sede à Rua Botucatu, 862 - São Paulo - SP, inscrita no CGC-MF sob o no 49.777.766/0001-76, neste ato representado pelo Diretor da BIREME, Dr. ABEL LAERTE PACKER, doravante denominado OPS/BIREME;

CONSIDERANDO o interesse convergente das partes na implantação e execução do Projeto Piloto de Implementação de Biblioteca Eletrônica de Revistas Científicas Internacionais para as Instituições de Ensino e Pesquisa do Estado de São Paulo, com o objetivo de contribuir para o desenvolvimento da pesquisa, através da aquisição de revistas eletrônicas cujo uso será compartilhado pela comunidade científica do Estado de São Paulo, utilizando para tanto a rede ANSP, 
RESOLVEM CELEBRAR O PRESENTE TERMO DE INSTITUIÇÃO DE CONSÓRCIO, sob as cláusulas e condições seguintes:

\section{Cláusula 1a - DO OBJETIVO}

Constitui OBJETIVO deste Termo de Instituição de Consórcio a instituição do Consórcio de Biblioteca Eletrônica de Revistas Científicas Internacionais para as Instituições de Ensino e Pesquisa do Estado de São Paulo, doravante denominado CONSÓRCIO, bem como o estabelecimento de condições gerais para a realização de atividades conjuntas tendentes à sua implementação.

$\S 1^{\circ}$ - O CONSÓRCIO tem como finalidade a aquisição conjunta de publicações eletrônicas de interesse das Instituições que o integram, fazendo-as disponíveis a cada uma destas, em igualdade de condições, nos termos aqui estabelecidos.

$\S 2^{\circ}$ - Integram o CONSÓRCIO as Instituições signatárias deste Termo de Instituição de Consórcio.

\section{Cláusula $2^{\mathrm{a}}$ - DA COORDENAÇÃO DO CONSÓRCIO}

A coordenação geral e operacional do CONSÓRCIO caberá ao Comitê Gestor.

$\S 1^{\circ}$ O Comitê Gestor do CONSÓRCIO é composto pelo Coordenador Geral, pelo Coordenador Operacional, por um representante de cada uma das Instituições convenentes que seja Coordenador ou Diretor de Sistema de Bibliotecas ou Biblioteca Central e por três consultores.

$\S 2^{\circ} \mathrm{O}$ Coordenador Geral será o coordenador do Projeto Piloto junto à FAPESP, que resultou no presente Termo de Instituição de Consórcio.

$\S 3^{\circ}$ O Coordenador Operacional e os três Consultores serão indicados pelo Coordenador Geral do Consórcio.

$\S 4^{\circ}$ Compete ao Comitê Gestor:

a) coordenar as atividades relativas à implantação, operação, manutenção e avaliação de uso da Biblioteca Eletrônica;

b) promover estudos para a incrementação da Biblioteca Eletrônica;

c) decidir sobre a assinatura de revistas que integrarão a Biblioteca Eletrônica;

d) definir as políticas de acesso e obtenção da informação na Biblioteca Eletrônica pela comunidade acadêmica de cada uma das Instituições componentes do CONSÓRCIO; 
e) deliberar sobre o ingresso de novas Instituições no CONSÓRCIO, o que se fará mediante a assinatura de Termo Aditivo a este instrumento, cabendo ao seu coordenador geral assinar o respectivo Termo Aditivo;

f) elaborar seu Regimento Interno.

\section{Cláusula $3^{\mathrm{a}}$ - DAS OBRIGAÇÕES DAS PARTES}

$\S 10$ Para a execução do objeto deste CONSÓRCIO competirá à USP, UNICAMP, UNESP, UFSCar, UNIFESP e OPS/BIREME:

a) cumprir as obrigações estabelecidas pelo Comitê Gestor do CONSÓRCIO;manter, quanto aos periódicos que vierem a integrar a Biblioteca Eletrônica, as assinaturas já existentes em suporte de papel;

b) manter, quanto aos periódicos que vierem a integrar a Biblioteca Eletrônica, as assinaturas já existentes em suporte de papel;

c) providenciar, quanto aos periódicos que vierem a integrar a Biblioteca Eletrônica, a substituição de títulos já assinados por outra Instituição integrante do CONSÓRCIO, de maneira a evitar a duplicidade de assinaturas pelas Instituições consorciadas;

d) ampliar o compartilhamento de informações entre as Instituições que integram o CONSÓRCIO, através do acesso às revistas da Biblioteca Eletrônica;

e) zelar pela manutenção adequada e permanente da infra-estrutura das respectivas redes eletrônicas e equipamentos, com a finalidade de garantir o acesso otimizado à Biblioteca Eletrônica;

f) garantir a padronização de procedimentos nas ações de integração operacional do CONSÓRCIO;

g) propiciar a disseminação do uso da Biblioteca Eletrônica junto à comunidade científica, garantindo o necessário treinamento dos potenciais usuários;

h) avaliar o uso das coleções eletrônicas e das coleções em papel, bem como da satisfação do usuário, através da utilização de indicadores padronizados, a serem definidos pelo Comitê Gestor do CONSÓRCIO;

i) participar de estudos interinstitucionais para a incrementação da Biblioteca Eletrônica;

j) outras decorrentes deste Termo de Instituição de Consórcio.

$\S 2^{\circ}$ Para a execução do objeto deste CONSÓRCIO competirá à FAPESP

a) adquirir e manter atualizada a base de dados das revistas da Biblioteca Eletrônica; 
b) adquirir e manter hardware e software necessários e adequados à instalação e funcionamento da Biblioteca Eletrônica;

c) zelar pela manutenção adequada e permanente da infra-estrutura da Rede ANSP, de maneira a garantir o pleno uso da Biblioteca Eletrônica;

d) garantir às instituições consorciadas o direito permanente de uso amplo e irrestrito das informações constantes da Biblioteca Eletrônica já adquirida e instalada na FAPESP;

e) Outras decorrentes deste Termo de Instituição de Consórcio.

\section{Cláusula $4^{\mathrm{a}}$ - DAS ALTERAÇÕES}

Este termo somente poderá ser alterado por acordo entre os partícipes, através de Termo Aditivo.

\section{Cláusula $5^{\mathrm{a}}$ - DA VIGÊNCIA}

Este Termo de Instituição de Consórcio vigorará pelo prazo de 3 (três ) anos, a contar da data de sua assinatura.

\section{Cláusula $6^{a}$ - DA RESCISÃO}

$\S 1^{\circ}$ Este Termo de Instituição de Consórcio poderá ser rescindido por acordo entre as partes ou unilateralmente, por qualquer delas, mediante comunicação escrita com antecedência mínima de 180 (cento e oitenta) dias, sem prejuízo das atividades porventura em desenvolvimento;

$\S 2^{\circ} \mathrm{A}$ Instituição que rescindir unilateralmente o Termo de Instituição de Consórcio, deixando assim de integrar o CONSÓRCIO, perderá o acesso à Biblioteca Eletrônica.

\section{Cláusula $7^{\mathrm{a}}$ - DO FORO}

$\S 1^{\circ}$ Para dirimir dúvidas que possam ser suscitadas na execução e interpretação do presente Termo de Instituição de Consórcio, as partes empregarão todos os esforços na busca de uma solução consensual. Não sendo possível, fica eleito o foro da Capital do Estado de São Paulo, em uma das Varas da Fazenda Pública, ou da Justiça Federal, Seção Judiciária de São Paulo, com exclusão de qualquer outro, mesmo privilegiado, conforme se trate de pessoa jurídica de Direito Público Estadual ou Federal.

$\S 2^{\circ}$ Relativamente à OPS/BIREME, para dirimir dúvidas que possam ser suscitadas na execução e interpretação do presente Termo de Instituição de Consórcio, as partes empregarão todos os 108 
esforços na busca de uma solução consensual. As controvérsias que surgirem entre as parte e que não puderem ser resolvidas amistosamente serão submetidas à arbitragem. $O$ tribunal de arbitragem será composto por um árbitro nomeado pela FAPESP, um pelas Universidades e um pela OPS/BIREME, que designarão o seu Presidente. As normas e o procedimento arbitral serão decididos pelos os árbitros. A decisão arbitral será final e inapelável.

E POR ESTAREM ASSIM JUSTAS E CONSORCIADAS, as partes assinam o presente em sete vias de igual forma e teor na presença das testemunhas abaixo.

São Paulo, 12 de março de 1999

\section{Fundação de Amparo à Pesquisa do}

\section{Universidade de São Paulo}

\section{Estado de São Paulo}

Prof. Dr. Carlos Henrique de Brito Cruz

Presidente

\section{Universidade Estadual de Campinas}

Prof. Dr. Hermano de Medeiros Ferreira Tavares Silva

Reitor

Universidade Federal de São Carlos

Prof. Dr. José Rubens Rebelatto

Reitor
Prof. Dr. Jacques Marcovitch

Reitor

\section{Universidade Estadual Paulista Júlio de Mesquita Filho}

Prof. Dr. Antonio Manoel dos Santos

Reitor

Universidade Federal de São Paulo

\section{Reitor}

Organização Panamericana da Saúde / Organização Mundial da Saúde

Dr. George A. O. Alleyne

Diretor

TESTEMUNHAS:

1

RG.

2.

RG. 


\section{Termo Aditivo ao Termo de Instituição do Consórcio de Cooperação Institucional}

Pelo presente instrumento administrativo de Termo Aditivo ao Termo de Instituição de Consórcio de Cooperação Institucional, as partes, a FUNDAÇÃO DE AMPARO À PESQUISA DO ESTADO DE SÃO PAULO, com sede à Rua Pio XI, n. 1500, São Paulo - SP, inscrito no CGC-MF sob n. 43.828.151/000145, neste ato representada pelo seu Presidente, Prof. Dr. CARLOS HENRIQUE DE BRITO CRUZ, doravante denominada FAPESP; a UNIVERSIDADE DE SÃO PAULO, com sede à Rua da Reitoria, $n$. 109, São Paulo - SP, inscrita no CGC-MF sob n. 63.025.530/0001-04, neste ato representada por seu Reitor Prof. Dr. JACQUES MARCOVITCH, doravante denominada USP; a UNIVERSIDADE ESTADUAL DE CAMPINAS, com sede à Cidade Universitária "Zeferino Vaz", Campinas - SP, inscrita no CGC-MF sob n. 46.068.425/0001-33, neste ato representada por seu Reitor, Prof. Dr. HERMANO DE MEDEIROS FERREIRA TAVARES, doravante denominada UNICAMP; a UNIVERSIDADE ESTADUAL PAULISTA JULIO DE MESQUITA FILHO, com sede à Alameda Santos, 647, São Paulo - SP, inscrita no CGC-MF sob n. 48.031.918/0001-24, neste ato representada por seu Reitor, Prof. Dr. ANTONIO MANOEL DOS SANTOS SILVA, doravante denominada UNESP; a UNIVERSIDADE FEDERAL DE SÃO CARLOS, com sede à Rodovia Washington Luiz, km 235, no Município de São Carlos - São Paulo - SP, inscrita no CGCMF sob o n. 45.358.058/0001-40, neste ato representada por seu Reitor, Prof. Dr. JOSÉ RUBENS REBELATTO, doravante denominada UFSCar; a UNIVERSIDADE FEDERAL DE SÃO PAULO, com sede à Rua Botucatu, 740 - São Paulo - SP, inscrita no CGC-MF sob o n. 60.453.032/0001-74, neste ato representada por seu Reitor, Prof. Dr. HELIO EGYDIO NOGUEIRA, doravante denominada UNIFESP; e a ORGANIZAÇÃO PANAMERICANA DA SAÚDE/ ORGANIZAÇÃO MUNDIAL DA SAÚDE (OPS/OMS), através do CENTRO LATINO AMERICANO E DO CARIBE PARA INFORMAÇÕES EM CIÊNCIAS DA SAÚDE (BIREME), com sede à Rua Botucatu, 862 - São Paulo - SP, inscrita no CGC-MF sob n. 49.777.766/0001-76, neste ato representado pelo Diretor da BIREME, Dr. ABEL LAERTE PACKER, doravante denominado OPS/BIREME;

CONSIDERANDO a deliberação sobre o ingresso de novas Instituições no Consórcio, levada a efeito pelo Comitê Gestor em reunião realizada em dezessete de abril do ano de dois mil, nos termos da Cláusula $2^{\text {a }}$, parágrafo $4^{\circ}$, alínea "e", do Termo de Instituição de Consórcio;

CONSIDERANDO que, em decorrência daquela deliberação, se faz necessária a alteração da redação da Cláusula $2^{a}$ do referido Termo, com o objetivo de regulamentar a representação das Instituições integrantes do Consórcio, RESOLVEM CELEBRAR O PRESENTE TERMO ADITIVO, dando à Cláusula $2^{\mathrm{a}}$ a seguinte redação:

Cláusula $2^{\mathrm{a}}$ - DA COORDENAÇÃO DO CONSÓRCIO 
A Coordenação Geral e Operacional do CONSÓRCIO caberá ao Comitê Gestor.

$\S 1^{\circ}$ Compõem o Comitê Gestor do CONSÓRCIO:

a) O Coordenador Geral;

b) O Coordenador Operacional;

c) 03 (três) Consultores;

d) 01 (hum) Representante de cada uma das instituidoras do CONSÓRCIO;

e) 01 (hum) Representante de cada Instituto de Ensino Superior e de Pesquisa, que vier a ingressar no CONSÓRCIO e que tiver a possibilidade de contribuir com o mínimo de $03 \%$ (três por cento) do valor da coleção da Biblioteca Eletrônica; os que não preencherem esse requisito terão 01 (hum) Representante eleito pelo conjunto dos Institutos nas mesmas condições.

$\S 2^{\circ} \mathrm{O}$ Coordenador Geral será o Coordenador do Projeto Piloto junto à FAPESP, que resultou no presente Termo de Instituição de Consórcio.

$\S 3^{\circ} \mathrm{O}$ Coordenador Operacional e os três Consultores serão indicados pelo Coordenador Geral do CONSÓRCIO;

$\S 4^{\circ}$ Os Representantes das Instituições referidas nas alíneas "d" e "e" do parágrafo $1^{\circ}$ deverão ser Coordenadores ou Diretores de Sistemas de Informação de Bibliotecas ou Biblioteca Central;

E por estarem justas e contratadas, as partes assinam o presente Termo Aditivo em sete (sete) vias de igual forma e teor na presença das testemunhas abaixo.

São Paulo, 25 de julho de 2000.

\section{Fundação de Amparo à Pesquisa do Estado de São Paulo}

Prof. Dr. Carlos Henrique de Brito Cruz Presidente

\section{Universidade Estadual de Campinas}

Prof.Dr. Hermano de Medeiros F.Tavares Reitor

\section{Universidade Federal de São Carlos}

\section{Universidade de São Paulo}

Prof. Dr. Jacques Marcovitch

Reitor

Universidade Estadual Paulista Julio

de Mesquita Filho

Prof. Dr. Antonio Manoel dos Santos

Reitor

Universidade Federal de São Paulo 
Prof. Dr. José Rubens Rebelatto Reitor
Prof. Dr. Helio Egydio Nogueira

Reitor

\section{BIREME}

Organização Panamericana da Saúde/

Organização Mundial da Saúde

Dr. Abel Laerte Packer

Diretor

TESTEMUNHAS:

R.G.

R.G. 


\section{Normas para a administração do consórcio de Cooperação Institucional}

Série Normas e Procedimentos, No 1

Atualização : Junho de 2001

Normas para a administração do Consórcio de Cooperação Institucional, visando à implantação e execução do Programa Biblioteca Eletrônica - ProBE

\section{Introdução}

Este documento estabelece normas para a administração do Consórcio de Cooperação Institucional, visando à implantação e à execução do Programa Biblioteca Eletrônica - ProBE, referente à aquisição de revistas científicas internacionais, cujo uso será compartilhado pela comunidade científica do Estado de São Paulo, utilizando para tanto a Rede ANSP - Academic Network at São Paulo.

\section{Constituição do Consórcio}

2.1 O Consórcio está constituído pelas Instituições Membros que celebraram entre si, em 18 de maio de 1999, o Termo de Instituição de Consórcio de Cooperação Institucional, a saber: Fundação de Amparo à Pesquisa do Estado de São Paulo - FAPESP

Universidade de São Paulo - USP

Universidade Estadual de Campinas - UNICAMP

Universidade Estadual Paulista "Júlio de Mesquita Filho" - UNESP

Universidade Federal de São Carlos - UFSCar

Universidade Federal de São Paulo - UNIFESP

Centro Latino-Americano e do Caribe de Informação em Ciências da Saúde BIREME/OPS/OMS

2.2 O Consórcio é aberto a adesões, de acordo com as deliberações sobre o ingresso de novas Instituições no Consórcio, especificadas no item 7 deste documento.

\section{Missão do Consórcio}

Contribuir para o desenvolvimento da pesquisa, expandindo e enriquecendo, de forma ágil e atualizada, os serviços e recursos de acesso à informação técnico-científica disponível em meio eletrônico para a comunidade científica, acadêmica e administrativa pertencente às Instituições componentes do Consórcio. 


\section{Objetivos do Consórcio}

Atuar cooperativamente visando à racionalização das coleções de revistas científicas, otimizando os recursos de informação necessários para as atividades de pesquisa da comunidade pertencente às Instituições consorciadas;

Adquirir em cooperação as publicações periódicas eletrônicas de interesse das Instituições que integram o Consórcio, fazendo-as disponíveis a cada uma destas em igualdade de condições;

Desenvolver capacitação de recursos humanos para a operação e uso de bases de dados de publicações eletrônicas.

\section{Coordenação do Consórcio}

5.1 A coordenação geral e operacional do Consórcio está sob a responsabilidade de um Comitê Gestor composto de um Coordenador Geral, um Coordenador Operacional, 3 (três) consultores, um representante de cada uma das instituidoras do Consórcio, um Representante de cada Instituição de Ensino Superior e de Pesquisa que vier a ingressar no Consórcio e que tiver a possibilidade de contribuir com o mínimo de 3\% (três por cento) do valor da coleção da Biblioteca Eletrônica. Os que não preencherem esse requisito terão um Representante eleito pelo conjunto das instituições nas mesmas condições.

5.2 O Coordenador Geral é o coordenador do respectivo Projeto na FAPESP;

5.3 O Coordenador Operacional e os três Consultores são escolhidos pelo Coordenador Geral.

\section{Competências}

6.1 Compete ao Comitê Gestor:

6.1.1 coordenar as atividades relativas à implantação, operação, manutenção e avaliação de uso da Biblioteca Eletrônica;

6.1.2 promover estudos para a incrementação da Biblioteca Eletrônica;

6.1.3 deliberar sobre a assinatura de revistas que integrarão a Biblioteca Eletrônica;

6.1.4 definir as políticas de acesso e obtenção da informação na Biblioteca Eletrônica pela comunidade de cada uma das Instituições componentes do Consórcio;

6.1.5 deliberar sobre o ingresso de novas Instituições no Consórcio, ouvidos todos os seus membros;

6.1.6 elaborar e alterar o seu Regimento Interno;

6.1.7 outras deliberações que se fizerem necessárias para o bom andamento do Consórcio. 
6.2 Compete às Instituições Membros do Consórcio:

6.2.1 cumprir com as obrigações estabelecidas pelo Comitê Gestor do Consórcio;

6.2.2 evitar a duplicidade de assinaturas, no âmbito do Consórcio, para a racionalização das coleções e otimização de recursos;

6.2.3 garantir recursos humanos capacitados para operacionalização do acesso à Biblioteca Eletrônica;

6.2.4 assegurar a manutenção adequada e permanente da infra-estrutura das respectivas redes eletrônicas e equipamentos, com a finalidade de garantir o acesso otimizado à Biblioteca Eletrônica;

6.2.5 garantir o uso de procedimentos padronizados nas ações de integração operacional do Consórcio;

6.2.6 propiciar a disseminação do uso da Biblioteca Eletrônica, garantindo o necessário treinamento dos potenciais usuários;

6.2.7 avaliar o uso das coleções eletrônicas e das coleções em papel, bem como da satisfação do usuário, através da utilização de indicadores padronizados, definidos pelo Comitê Gestor do Consórcio;

6.2.8 garantir o fluxo da informação relativo às atividades de Consórcio junto `a sua Instituição e cooperar neste fluxo da informação entre as Instituições;

6.2.9 participar de estudos interinstitucionais para a incrementação da Biblioteca Eletrônica e a ampliação de seu uso compartilhado;

6.2.10 outras atividades que se fizerem necessárias para o bom andamento do Consórcio.

6.3 Compete à FAPESP:

6.3.1 adquirir e manter atualizada a base de dados das revistas da Biblioteca Eletrônica;

6.3.2 adquirir e manter hardware e software necessários e adequados à instalação e funcionamento da Biblioteca Eletrônica;

6.3.3 zelar pela manutenção adequada e permanente da infra-estrutura da Rede ANSP, de maneira a garantir o pleno uso da Biblioteca Eletrônica;

6.3.4 garantir às Instituições Membros do Consórcio o direito permanente de uso amplo e irrestrito das informações constantes da Biblioteca Eletrônica já adquirida e instalada na FAPESP;

6.3.5 outras atividades que se fizerem necessárias para o bom andamento do Consórcio. 


\section{Deliberação sobre o Ingresso de Novas Instituições no Consórcio}

O ingresso de novas Instituições no Consórcio se dará mediante assinatura de Termo Aditivo ao Termo de Instituição de Consórcio de Cooperação Institucional. Para tanto as Instituições candidatas deverão preencher os seguintes requisitos:

Estar desenvolvendo atividades de ensino e/ou pesquisa;

Possuir usuários potenciais com projetos de pesquisa em andamento;

Possuir linhas de pesquisa com produção científica (teses, dissertações, monografias e artigos científicos);

Dispor de recursos humanos capacitados para a operacionalização do acesso à Biblioteca Eletrônica;

Oferecer títulos que venham a incrementar a coleção da Biblioteca Eletrônica, observados os requisitos especificados no item 8 ;

Dispor de infra-estrutura de rede eletrônica e equipamentos, com a finalidade de garantir o acesso otimizado à Biblioteca Eletrônica;

Contribuir com o mínimo de 3\% do valor da coleção da Biblioteca Eletrônica.

\section{Requisitos para a inclusão de novas Revistas Científicas no ProBE}

Estar indexada nas principais bases de dados referenciais internacionais especializadas, especialmente no "Web of Science" e "Current Contents Connect";

Ser título integrante do acervo da maioria das Instituições componentes do Consórcio, mas ainda não disponível na Biblioteca Eletrônica, ou então, ser título novo de interesse da maioria das Instituições Membros do Consórcio. 


\section{Carta explicativa acompanhando os instrumentos de coleta de dados}

Ref.: Informação para Pesquisa Científica

São Paulo, 16 de Outubro de 2001.

Prezado(a) Senhor(a),

Conforme contato telefônico prévio, envio em anexo o instrumento de coleta de dados referente a minha pesquisa de Mestrado em Ciência da Informação e Documentação da Escola de Comunicações e Artes da Universidade de São Paulo (ECA/USP), cujo tema relaciona-se à globalização do mercado de periódicos científicos eletrônicos no contexto de um consórcio de bibliotecas universitárias do Estado de São Paulo e de Instituições Nacionais de pesquisa, como mecanismo de democratização do acesso à informação científica.

Esse projeto tem por objetivo analisar as relações entre a globalização de mercados e as mudanças no fluxo de transmissão e acumulação do conhecimento científico, bem como as alterações sofridas nas políticas de gerenciamento de coleções em bibliotecas universitárias brasileiras pela ação de um consórcio - dada a sua representatividade - com ênfase na análise do mercado internacional de periódicos científicos eletrônicos.

Esta pesquisa visa coletar dados qualitativos que subsidiem a pesquisa em andamento visando confrontá-los com a literatura corrente nacional e internacional especializada e estudos de outras áreas com temática correlata. Deste modo, as instituições não serão identificadas, assim como os entrevistados, garantindo o seu sigilo e a confidencialidade.

Quanto ao instrumento de coleta, esclareço que:

1. Caso tenha dúvidas sobre alguma das questões formuladas, por favor envie-me um e-mail de modo que tentarei esclarecê-las e reaplicá-las em momento posterior;

2. O pré-teste indicou um tempo estimado de 25 minutos para o preenchimento total deste instrumento. O prazo máximo para entrega deste é 05/11/2001.

Atenciosamente,

Antonio Marcos Amorim

Mestrando em Ciência da Informação

Escola de Comunicações e Artes / USP

E-mail: marcos.usp@starmedia.com 


\section{Questionários enviados}

\subsection{Modelo estruturado de questionário I: Bibliotecários membros do comite gestor do consórcio ProBE}

1. A sua instituição tem uma política de desenvolvimento de coleções oficial e expressa em um documento ? Se não, qual o motivo de sua ausência ?

2. Dentre as ferramentas de avaliação periódica de coleções, quais você considera as mais importantes para renovação das coleções de periódicos eletrônicos ? O custo por artigo está entre estas ? E o fator de impacto - mantido pelo ISI, através do Journal Citation Report - tenderá a não ser mais utilizado ?

3. Como o ProBE vem otimizando o uso de suas coleções eletrônicas ? Com o consórcio, como sua biblioteca tem cumprido sua parte no estabelecimento de novas políticas de acesso, de modo a tornar suas coleções eletrônicas com maior e melhor uso pelos pesquisadores e estudantes ? Quais as atuais limitações e dificuldades encontradas na sua opinião ?

4. Em sua opinião, qual é a tendência na maioria das bibliotecas que você conhece quanto às assinaturas de periódicos científicos ? Havendo uma queda de recursos financeiros para aquisição, há outras possibilidades de acesso a artigos científicos já implantadas em sua instituição ? Se não, porquê ?

5. Dentre os grandes editores e maiores agentes distribuidores de periódicos científicos, a seu ver há um único que detém a maioria absoluta das assinaturas na América Latina ? Como se divide esse mercado ? Se possível, corrobore sua opinião com algum dado.

6. Uma mudança que parece ocorrer nas bibliotecas é o direcionamento das pesquisas científicas para artigos mais recentes e que estão disponíveis em formato eletrônico, tornando a própria indexação da literatura mais antiga um trabalho em curva descendente. Sua biblioteca tem acompanhado essa tendência ? Há dados do setor de referência que corroboram essa interferência na pesquisa científica? 
7. São do seu conhecimento estatísticas que comprovem um crescimento do uso das coleções eletrônicas nos últimos 6 (seis) meses feita pelo consórcio ? Se sim, como é feita a coleta de dados?

8. O autor Edward Shreeves expõe que "... nos últimos anos, houve um crescimento acelerado do volume e diversidade de formatos de documentos disponíveis, tornando o gerenciamento de coleções uma atividade cada vez mais complexa, onde grande parte das bibliotecas - e aí incluímos as maiores - ainda não possuem ferramentas ou mecanismos eficazes para administrar suas coleções e oferecer mais informação (grifo meu) aos usuários, que as solicitam num prazo cada vez menor". A sua experiência confirma esta afirmação ? Justifique.

9. O empréstimo interbibliotecário e o envio de documentos (document delivery) aumentou ou diminuiu com a inserção dos periódicos eletrônicos, em especial com o acesso oferecido pelo ProBE ? Você acha que os consórcios em geral reforçam o atendimento sob demanda ? O pagamento deste serviço deveria ser subsidiado pela instituição ou órgão de fomento ou até mesmo ser custeado pelo próprio pesquisador?

10. Quantos bibliotecários em sua instituição trabalham diretamente com o gerenciamento de coleções de periódicos científicos?

$\square 1 \square 2$ a $3 \square 4$ ou mais $\square$ Nenhum

11. (Se sua resposta à questão anterior for Nenhum, passe para a questão seguinte). Desses profissionais, quantos possuem o domínio de ferramentas para trabalhar com a Internet (algum editor HTML - como DreamWeaver, Front Page, etc. - FTP) ?

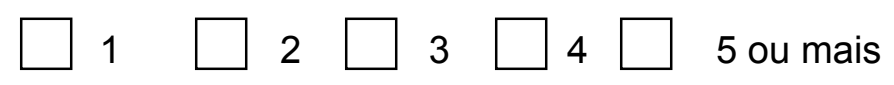

12. Como sua biblioteca cobra pelos serviços relacionados ao uso de periódicos científicos ? Informe sobre cada um dos serviços existentes, conforme indicado a seguir: 
a) Xerox

$\square$ Não oferecido $\square$ Pago $\square$ Gratuito

b) Empréstimo Interbibliotecário

$\square$ Não oferecido $\square$ Pago $\square$ Gratuito

c) Envio de documentos ou Document delivery (Ariel, etc.)

$\square_{\text {Não oferecido }} \square_{\text {Pago }} \square$ Gratuito

d) Download de artigos

$\square$ Não oferecido $\square$ Pago $\square$ Gratuito

e) Empréstimo domiciliar

$\square$ Não oferecido $\square$ Pago $\square$ Gratuito

f) Pesquisa em bases de dados

$\square$ Não oferecido $\square$ Pago $\square$ Gratuito

13. Quais são, em seu ponto de vista, as outras iniciativas nacionais na América Latina que merecem destaque enquanto projetos de democratização do acesso à informação, tratando-se de consórcios ?

14. A política de seleção de publicações feita por consórcios está restrita a um determinado tipo de publicação: a informação científica e altamente especializada, cujo mercado trata tal informação sobretudo como um bem mercantil, dado o alto custo de suas assinaturas. Um consórcio de bibliotecas brasileiras não poderia contemplar outro tipo de publicação ? Se sim, qual tipo e porquê? 


\subsection{Modelo estruturado II de questionário: Agentes distribuidores de periódicos científicos do mercado brasileiro}

1. É inegável que a globalização de mercados e a migração das publicações científicas para o universo eletrônico fez com que a maioria dos grandes agentes distribuidores realinhassem suas políticas de vendas em todo o mundo, América Latina inclusive. Como o senhor tem observado o comportamento dos preços das publicações nos últimos anos e qual a interferência destes nessas políticas ?

2. Qual é o total estimado de periódicos eletrônicos oferecidos para o mercado brasileiro atualmente, após a globalização ? Há previsões de crescimento da oferta atual ?

3. Ao participar diretamente do consórcio ProBE como uma das empresas escolhidas para fornecer um grande leque de publicações periódicas científicas, indiretamente estão contribuindo para o processo de democratização da informação nas Universidades. Como o senhor analisa esta nova realidade?

4. Em relação ao mercado global de periódicos científicos, nos últimos tempos temos assistido a uma série de fusões e compras entre grandes empresas fornecedoras de periódicos. No caso específico da América Latina, qual a sua opinião sobre este mercado para os próximos anos ? Qual é a estratégia de ação de sua empresa?

5. As bibliotecas têm incrementado seus programas de marketing e divulgação visando aumentar o uso de periódicos eletrônicos, sobretudo daqueles considerados os mais importantes. O senhor acha, de um modo geral, eficazes tais programas de recuperação ?

6. Recentemente, todos os grandes agentes distribuidores promoveram significativas mudanças em suas interfaces de busca e consulta, chegando mesmo alguns estudiosos a afirmar que estas já suplantam em grande parte as existentes nas próprias bibliotecas. Serão feitos investimentos e novos desenvolvimentos para esta área nos próximos anos por sua companhia?

7. Qual a sua opinião sobre a mudança do impresso para uma cultura digital nos meios acadêmico e científico ? O uso dos periódicos eletrônicos tenderá a substituir o próprio uso das coleções impressas? 
8. A política de seleção de publicações feita pelo consórcio está restrita a um determinado tipo de publicação: a informação científica e altamente especializada, cujo mercado trata tal informação sobretudo como um bem mercantil, dado o relativo alto custo de suas assinaturas. A seu ver, sua empresa teria condições de oferecer produtos de outro tipo para o consórcio, com um custo significativamente mais baixo ? Se sim, quais seriam as características desse e as condições para seu lançamento ? 


\subsection{Roteiro de entrevista pré-estruturada realizada junto a Coordenadoria Operacional e Gerência do Consórcio}

1. É inegável que a globalização de mercados e a migração das publicações científicas para o universo eletrônico obrigou os grandes agentes distribuidores a realinharem suas políticas de atuação em todo o mundo, inclusive na América Latina. Dado o crescente aumento de custos de assinaturas de periódicos, quais as saídas propostas pelo comitê gerenciador do consórcio para essa tendência infoexcludente?

2. O valor econômico e a mercantilização da informação, tida aí como mercadoria, é uma questões bastante polêmica. Este modelo provoca uma dupla perda a quem a produz, no caso do pesquisador: quando este produz tal informação, pois o conhecimento depende de uma série de trocas de conhecimento e processos de comunicação que não têm como ser mensurados economicamente e no momento de publicá-la, pois ele literalmente paga por isto. E, além disso, sabendo que, no final, a informação é vista como um "bem público". Não deveriam os grandes editores e agentes distribuidores custear ao menos parte de todo este processo? Como você analisa essa questão ?

3. Na sua opinião, como as mudanças trazidas com a Internet têm afetado as políticas de desenvolvimento de coleções cooperativas, sobretudo através daquelas mudanças advindas de uma cultura do digital já presentes no cotidiano do pesquisador ? Como os grandes editores e agentes distribuidores têm (re)agido diante dessa nova realidade?

4. Dentre os grandes editores e maiores agentes distribuidores de publicações de periódicos científicos, a seu ver há algum que detenha a maioria absoluta das assinaturas na América Latina ? Como se divide esse mercado ? Se possível, corrobore sua opinião com algum dado.

5. Qual o universo de periódicos científicos coberto pelo consórcio ProBE, em termos quantitativos ? E em termos qualitativos, quais são as áreas do conhecimento beneficiadas por este ? Há possibilidades de sua expansão? 
6. Dentre as ferramentas de avaliação periódica, quais o consórcio considera as mais importantes para renovação das coleções de periódicos eletrônicos ? O custo por artigo está entre estas? E o fator de impacto - mantido pelo ISI, através do Journal Citation Report tenderá a não ser mais utilizado ?

7. Quanto o consórcio ProBE tem gasto por ano, nos últimos dois anos, com assinaturas de periódicos eletrônicos ? No caso da diminuição do total assinado por uma instituiçãomembro, como é feita a compensação financeira ? E em termos de títulos, caso um deles seja encerrado?

8. Como o ProBE vem otimizando o uso de suas coleções eletrônicas ? Quais as atuais limitações e dificuldades encontradas na sua opinião?

9. São do seu conhecimento estatísticas que comprovem um crescimento do uso das coleções eletrônicas nos últimos seis meses feitas pelo consórcio ? Se sim, como é feita a coleta de dados?

10. Você acha que o consórcio reforça o atendimento sob demanda e pago pelos serviços de empréstimo interbibliotecário e de envio de documentos (document delivery) ou estes deveriam ser subsidiados pela instituição ou órgão de fomento, ou até mesmo serem gratuitos?

11. Quantas instituições solicitaram sua inclusão no consórcio e foram contempladas ? E as não contempladas, em geral por que não o foram ?

12. De que forma as políticas de informação nacionais têm beneficiado - ou, se for o caso, dificultado - a ação do consórcio de periódicos eletrônicos ?

13. Como devem ficar - e me corrija se a informação estiver incorreta - a política e as atividades de desenvolvimento de coleções do consórcio com a mudança da instituição mantenedora (troca da FAPESP pela CAPES) ?

14. Dentre as barreiras políticas, quais podem ser mencionadas como as mais importantes contra a expansão do consórcio de periódicos eletrônicos - ProBE ? E dentre as barreiras financeiras, quais deveriam ser citadas? 
15. A política de seleção de publicações feita pelo consórcio está restrita a um determinado tipo de publicação: a informação científica e altamente especializada, cujo mercado trata tal informação sobretudo como um bem mercantil, dado o alto custo de suas assinaturas. Um consórcio de bibliotecas brasileiras não poderia contemplar outro tipo de publicação ? Se sim, qual tipo e porquê ?

16. Quais são, em seu ponto de vista, as outras iniciativas nacionais na América Latina que merecem destaque enquanto projetos de democratização do acesso a informação, tratando-se de consórcios?

\section{Respostas modelo I : Bibliotecários de desenvolvimento de coleções do consórcio}

\subsection{Instituição respondente 1 do consórcio Probe}

1. A sua instituição tem uma política de desenvolvimento de coleções oficial e expressa em um documento ? Se não, qual o motivo de sua ausência ?

Tem.

2. Dentre as ferramentas de avaliação periódica de coleções, quais você considera as mais importantes para renovação das coleções de periódicos eletrônicos ? O custo por artigo está entre estas ? E o fator de impacto - mantido pelo ISI, através do Journal Citation Report - tenderá a não ser mais utilizado ?

De acordo com a política vigente, o custo é um fator importante a ser considerado. O fator de impacto é utilizado por várias bibliotecas que compõem o Sistema além da adequação do conteúdo ao currículo acadêmico e às linhas de pesquisa em desenvolvimento. Considera-se também a língua, a demanda, conveniência do formato entre outro.

3. Como o ProBE vem otimizando o uso de suas coleções eletrônicas ?

O ProBE além de tornar acessível um maior número de publicações eletrônicas, foi fundamental no incentivo ao uso dessas publicações.

Com o consórcio, como sua biblioteca tem cumprido sua parte no estabelecimento de novas políticas de acesso, de modo a tornar suas coleções eletrônicas com maior e melhor uso pelos pesquisadores e estudantes ? 
Sim.

Quais as atuais limitações e dificuldades encontradas na sua opinião ?

O acesso às publicações eletrônica apesar de já muito divulgado, precisa ser melhor divulgado e incentivado pois ainda há resistência ao uso. Isso ocorre, a meu ver, pelo desconhecimento do assunto por parte de muitos usuários e até mesmo por dos profissionais bibliotecários. Há ainda a questão da infra-estrutura disponível, nem sempre adequada às necessidades e/ou expectativas dos usuários (velocidade da rede, tipo e quantidade de equipamento, ambientes adequados de pesquisa).

4. Em sua opinião, qual é a tendência na maioria das bibliotecas que você conhece quanto às assinaturas de periódicos científicos ?

Observa-se claramente uma tendência à participação em consórcios e/ou compartilhamentos bem como uso de softwares para troca eletrônica de artigos científicos.

Havendo uma queda de recursos financeiros para aquisição, há outras possibilidades de acesso a artigos científicos já implantadas em sua instituição ? Se não, porquê ?

Queda de recursos financeiros é sempre um item de discussão nos ambientes de bibliotecas mas não vejo isso como um problema. Pode até haver queda nos orçamentos específicos (oficiais) das instituições mas existem muitos recursos disponíveis que podem ser obtidos através de projetos, consórcios, parcerias entre outras formas de obtenção. Eu entendo que tem havido maiores recursos que podem ser obtidos e isso depende muito da capacidade dos profissionais bibliotecários e até mesmo da instituições para obtê-los. Além desses outros recursos, já foram citadas as possibilidades de participação em consórcios/ compartilhamentos e também a troca eletrônica de documentos, sob demanda. Aliado a isso, há muita informação de qualidade disponível gratuitamente e nesse sentido, mais uma vez cabe ao profissional bibliotecário indentificá-las e divulgá-las aos usuários.

5. Dentre os grandes editores e maiores agentes distribuidores de periódicos científicos, a seu ver há um único que detém a maioria absoluta das assinaturas na América Latina ? Como se divide esse mercado ? Se possível, poderia corrobore sua opinião com algum dado. 
Ainda há na América Latina um agente fornecedor que detém a maioria das assinaturas mas outros agentes já estão conseguindo, através da prestação de bons serviços, se inserir no contexto lationoamericano. A tendência é que, muito em breve, esse agente não seja mais "o maior". Isso também deve-se ao fato de muitas instituições estarem efetivando suas assinaturas através dos próprios editores que, muitas vezes, oferecem bons serviços a um custo mais acessível. Não disponho de dados oficiais para ilustrar minha opinião.

6. Uma mudança que parece ocorrer nas bibliotecas é o direcionamento das pesquisas científicas para artigos mais recentes e que estão disponíveis em formato eletrônico, tornando a própria indexação da literatura mais antiga um trabalho em curva descendente. Sua biblioteca tem acompanhado essa tendência ? Há dados do setor de referência que corroboram essa interferência na pesquisa científica ?

Essa informação pode ser melhor fornecida por bibliotecários de referência que atuam diretamente nas bibliotecas das diferentes áreas do conhecimento. No meu caso em especial, não tenho como informar uma vez que respondo por um Sistema composto por 39 bibliotecas, com diferentes realidades em função dos públicos a que se destinam.

7. São do seu conhecimento estatísticas que comprovem um crescimento do uso das coleções eletrônicas nos últimos 6 (seis) meses feita pelo consórcio ? Se sim, como é feita a coleta de dados?

Sim existem. A coleta de dados é feita eletronicamente pelas instituições participantes do consórcio (ProBE).

8. O autor Edward Shreeves expõe que "... nos últimos anos, houve um crescimento acelerado do volume e diversidade de formatos de documentos disponíveis, tornando o gerenciamento de coleções uma atividade cada vez mais complexa, onde grande parte das bibliotecas - e aí incluímos as maiores - ainda não possuem ferramentas ou mecanismos eficazes para administrar suas coleções e oferecer mais informação (grifo meu) aos usuários, que as solicitam num prazo cada vez menor". A sua experiência confirma esta afirmação ? Justifique.

Sim. Por trabalhar num sistema de biblioteca de uma instituição de excelência em nível de graduação e pós-graduação, com alto índice de produção científica baseada nas pesquisas que desenvolve, o volume de assinatura de periódicos é o maior do país, ultrapassando 9 (nove) mil. Para gerenciar toda a documentação relativa a essas 9 (nove) mil assinaturas, 
em diferentes formatos, está cada vez mais complexo o trabalho. Isso tem gerado um esforço maior dos profissionais responsáveis por essa atividade e tem, cada vez mais, requisitado sistemas informatizados mais sofisticados para o seu efetivo gerenciamento.

9. O empréstimo interbibliotecário e o envio de documentos (document delivery) aumentou ou diminuiu com a inserção dos periódicos eletrônicos, em especial com o acesso oferecido pelo ProBE ?

O ProBE engloba poucas instituições no âmbito do Estado de São Paulo mesmo assim observa-se uma diminuição natural na comutação bibliográfica no Estado. E, isso ocorrerá em escala nacional quando estiver melhor consolidado o Portal de Periódicos da CAPES

Você acha que os consórcios em geral reforçam o atendimento sob demanda ?

Sim.

O pagamento deste serviço deveria ser subsidiado pela instituição ou órgão de fomento ou até mesmo ser custeado pelo próprio pesquisador?

Essa é uma questão polêmica e depende da política de cada instituição. O que deve estar claro é a não obtenção de lucro por parte de quem fornece a informação ao usuário que também não irá gerar lucro. Para instituições particulares (empresas) deve ser cobrado, no mínimo, um valor para cobrir os custos pois, caso contrário, a instituição fornecedora não conseguirá se manter. Aliás, aqui está mais mais uma forma de obtenção de recursos para as instituições públicas.

10. Quantos bibliotecários em sua instituição trabalham diretamente com o gerenciamento de coleções de periódicos científicos ?

$\square 1 \square 2$ a $3 \square 4$ ou mais $\square$ Nenhum

11. (Se sua resposta à questão anterior for Nenhum, passe para a questão seguinte). Desses profissionais, quantos possuem o domínio de ferramentas para trabalhar com a Internet (algum editor HTML - como DreamWeaver, Front Page, etc. - FTP) ?

$\square 1 \square 2 \square 3 \square 4 \square 5$ ou mais 
12. Como sua biblioteca cobra pelos serviços relacionados ao uso de periódicos científicos ? Informe sobre cada um dos serviços existentes, conforme indicado a seguir:

a) Xerox

$\square$ Não oferecido $\square$ Pago $\square$ Gratuito

b) Empréstimo Interbibliotecário

$\square$ Não oferecido $\square$ Pago $\square$ Gratuito

c) Envio de documentos ou Document delivery (Ariel, etc.)

Não oferecido $\square$ Pago $\square$ Gratuito

d) Download de artigos

$\square_{\text {Não oferecido }} \square$ Pago $\square$ Gratuito

e) Empréstimo domiciliar

$\square$ Não oferecido $\square$ Pago $\square$ Gratuito

f) Pesquisa em bases de dados

$\square$ Não oferecido $\square$ Pago $\square$ Gratuito

As 39 bibliotecas oferecem os serviços listados e a cobrança ou não depende de cada uma das unidades de ensino/pesquisa as quais estão vinculadas administrativamente.

13. Quais são, em seu ponto de vista, as outras iniciativas nacionais na América Latina que merecem destaque enquanto projetos de democratização do acesso à informação, tratando-se de consórcios?

Além do ProBE há a inciativa da CAPES com o Portal de Periódicos que atende 97 instituições de norte a sul do país e, com certeza, é a maior manifestação de democratização da informação na America Latina. No Rio de Janeiro também há um programa de compartilhamento que envolve instituições públicas e privadas de ensino e pesquisa. Para 
acesso a bases referenciais, o maior compartilhamento está no âmbito do CRUESP - a ERL, que envolve as três universidades estaduais paulistas e mantém à disposição da comunidade científica cerca de 40 títulos.

14. A política de seleção de publicações feita por consórcios está restrita a um determinado tipo de publicação: a informação científica e altamente especializada, cujo mercado trata tal informação sobretudo como um bem mercantil, dado o alto custo de suas assinaturas. Um consórcio de bibliotecas brasileiras não poderia contemplar outro tipo de publicação ? Se sim, qual tipo e porquê ?

Claro que sim, principalmente em se tratando de bibliotecas públicas e escolares. No caso das bibliotecas públicas, a Biblioteca Nacional tem buscado algum forma de consórcio/compartilhamento, em especial para a catalogação. Com certeza iniciativas com relação a compartilhamento de outros tipos de publicações também deve ocorrer a partir da experiência das bibliotecas universitárias. Mas, esse processo, com certeza, será mais demorado. 


\subsection{Instituição respondente 2 do consórcio ProBE}

1. A sua instituição tem uma política de desenvolvimento de coleções oficial e expressa em um documento ? Se não, qual o motivo de sua ausência ?

Não. O desenvolvimento de coleções está diretamente vinculado aos objetivos da instituição.

2. Dentre as ferramentas de avaliação periódica de coleções, quais você considera as mais importantes para renovação das coleções de periódicos eletrônicos ? O custo por artigo está entre estas ? E o fator de impacto - mantido pelo ISI, através do Journal Citation Report - tenderá a não ser mais utilizado ?

Custos e estatísticas de uso. Não acredito que o fator de impacto tenderá a ser a ferramenta mais usada para a avaliação das coleções.

3. Como o ProBE vem otimizando o uso de suas coleções eletrônicas ? Com o consórcio, como sua biblioteca tem cumprido sua parte no estabelecimento de novas políticas de acesso, de modo a tornar suas coleções eletrônicas com maior e melhor uso pelos pesquisadores e estudantes ? Quais as atuais limitações e dificuldades encontradas na sua opinião ?

O ProBE tem ampliado o acesso às revistas eletrônicas. As limitações são o controle por IP, que dificulta o acesso para os usuários beneficiados, mas que estão fora do campus da universidade. Uma outra dificuldade é a questão dos links para as bases de dados bibliográficas.

4. Em sua opinião, qual é a tendência na maioria das bibliotecas que você conhece quanto às assinaturas de periódicos científicos ?

A tendência é avaliar o custo / benefício das assinaturas, buscar a ampliação do acesso através de parcerias (consórcios).

Havendo uma queda de recursos financeiros para aquisição, há outras possibilidades de acesso a artigos científicos já implantadas em sua instituição ? Se não, porquê ?

Sim. Através da identificação de acesso gratuito, uso através das bibliotecas que fazem parte da rede. 
5. Dentre os grandes editores e maiores agentes distribuidores de periódicos científicos, a seu ver há um único que detém a maioria absoluta das assinaturas na América Latina ? Como se divide esse mercado ? Se possível, poderia corrobore sua opinião com algum dado.

Elsevier, Academic Press, EBSCO e SWETS. Não sei a proporção.

6. Uma mudança que parece ocorrer nas bibliotecas é o direcionamento das pesquisas científicas para artigos mais recentes e que estão disponíveis em formato eletrônico, tornando a própria indexação da literatura mais antiga um trabalho em curva descendente. Sua biblioteca tem acompanhado essa tendência ? Há dados do setor de referência que corroboram essa interferência na pesquisa científica ?

$\mathrm{Na}$ área da saúde foi sempre uma tendência. Depende da área. Os dados vêm do serviço de acesso às coleções (consulta local na biblioteca) e do serviço de comutação bibliográfica.

7. São do seu conhecimento estatísticas que comprovem um crescimento do uso das coleções eletrônicas nos últimos 6 (seis) meses feita pelo consórcio ? Se sim, como é feita a coleta de dados?

Sim, informadas pelas próprias editoras ou agregadores.

8. O autor Edward Shreeves expõe que "... nos últimos anos, houve um crescimento acelerado do volume e diversidade de formatos de documentos disponíveis, tornando o gerenciamento de coleções uma atividade cada vez mais complexa, onde grande parte das bibliotecas - e aí incluímos as maiores - ainda não possuem ferramentas ou mecanismos eficazes para administrar suas coleções e oferecer mais informação (grifo meu) aos usuários, que as solicitam num prazo cada vez menor". A sua experiência confirma esta afirmação ? Sim. Justifique.

(Não justificada) 
9. O empréstimo interbibliotecário e o envio de documentos (document delivery) aumentou ou diminuiu com a inserção dos periódicos eletrônicos, em especial com o acesso oferecido pelo ProBE?

A tendência é diminuir os pedidos que vêem das bibliotecas universitárias, mas não de usuários individuais e outras bibliotecas

Você acha que os consórcios em geral reforçam o atendimento sob demanda ?

Sim.

O pagamento deste serviço deveria ser subsidiado pela instituição ou órgão de fomento ou até mesmo ser custeado pelo próprio pesquisador?

10. Quantos bibliotecários em sua instituição trabalham diretamente com o gerenciamento de coleções de periódicos científicos ?

$\square 1 \square 2$ a $3 \square 4$ ou mais $\square$ Nenhum

11. (Se sua resposta à questão anterior for Nenhum, passe para a questão seguinte). Desses profissionais, quantos possuem o domínio de ferramentas para trabalhar com a Internet (algum editor HTML - como DreamWeaver, Front Page, etc. - FTP) ?

1
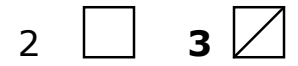

$4 \square$

5 ou mais

12. Como sua biblioteca cobra pelos serviços relacionados ao uso de periódicos científicos ? Informe sobre cada um dos serviços existentes, conforme indicado a seguir:

a) Xerox

$\square$ Não oferecido $\square$ Pago $\square$ Gratuito

b) Empréstimo interbibliotecário

$\square$ Não oferecido $\square$ Pago $\square$ Gratuito 
c) Envio de documentos ou Document delivery (Ariel, etc.)

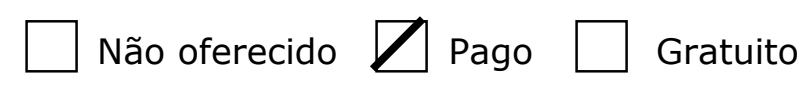

d) Download de artigos

$\square_{\text {Não oferecido }} \square_{\text {Pago }} \square$ Gratuito

e) Empréstimo domiciliar

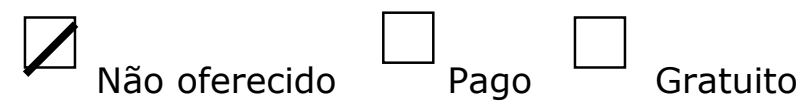

f) Pesquisa em bases de dados

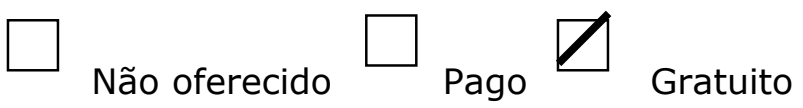

13. Quais são, em seu ponto de vista, as outras iniciativas nacionais na América Latina que merecem destaque enquanto projetos de democratização do acesso à informação, tratando-se de consórcios?

Ainda não tem um consórcio funcionando na América Latina, para acesso a revistas eletrônicas.

14. A política de seleção de publicações feita por consórcios está restrita a um determinado tipo de publicação: a informação científica e altamente especializada, cujo mercado trata tal informação sobretudo como um bem mercantil, dado o alto custo de suas assinaturas. Um consórcio de bibliotecas brasileiras não poderia contemplar outro tipo de publicação ? Se sim, qual tipo e porquê ?

Acho que não. 


\subsection{Instituição respondente 3 do consórcio ProBE}

1. A sua instituição tem uma política de desenvolvimento de coleções oficial e expressa em um documento ? Se não, qual o motivo de sua ausência ?

Temos uma política de desenvolvimento de coleções que está em estudo e por isso ainda não temos o documento. Temos previsão de publicá-la em 2002.

2. Dentre as ferramentas de avaliação periódica de coleções, quais você considera as mais importantes para renovação das coleções de periódicos eletrônicos ? O custo por artigo está entre estas ? E o fator de impacto - mantido pelo ISI, através do Journal Citation Report - tenderá a não ser mais utilizado ?

Os parâmetros que temos utilizado para avaliação de nossas coleções são: fator de impacto, vinculação a projetos de pesquisa em andamento, custo, avaliação da comunidade.

3. Como o ProBE vem otimizando o uso de suas coleções eletrônicas ? Com o consórcio, como sua biblioteca tem cumprido sua parte no estabelecimento de novas políticas de acesso, de modo a tornar suas coleções eletrônicas com maior e melhor uso pelos pesquisadores e estudantes ? Quais as atuais limitações e dificuldades encontradas na sua opinião ?

A otimização do uso das coleções do ProBE tem sido feita através da maior divulgação dos serviços oferecidos. Temos procurado ampliar o número de títulos oferecidos, principalmente os que atendam a diversas Unidades em localidades diferentes. A maior limitação atual é a verba para pagamento destes recursos.

4. Em sua opinião, qual é a tendência na maioria das bibliotecas que você conhece quanto às assinaturas de periódicos científicos ? Havendo uma queda de recursos financeiros para aquisição, há outras possibilidades de acesso a artigos científicos já implantadas em sua instituição ? Se não, porquê ?

Sim, o compartilhamento de acervos, seja ele através de consórcios como o ProBE, utilização de acervos disponíveis para acesso. Dentro da própria instituição, poderia citar a não duplicação (grifo do respondente) de títulos para diferentes Unidades, compartilhando este acervo, seja por acesso eletrônico disponibilizado para todo o range de IP da Universidade ou através do empréstimo interbibliotecário ou fornecimento de cópias via Ariel. 
5. Dentre os grandes editores e maiores agentes distribuidores de periódicos científicos, a seu ver há um único que detém a maioria absoluta das assinaturas na América Latina ? Como se divide esse mercado ? Se possível, poderia corrobore sua opinião com algum dado.

Dentre os grandes editores, principalmente de periódicos eletrônicos, temos: a formação de cartéis, como é o caso da Elsevier que recentemente incorporou a Academic Press; necessidade dos pequenos editores de vincularem-se a maiores ou até mesmo agentes, para poderem disponibilizar seus periódicos eletronicamente.

6. Uma mudança que parece ocorrer nas bibliotecas é o direcionamento das pesquisas científicas para artigos mais recentes e que estão disponíveis em formato eletrônico, tornando a própria indexação da literatura mais antiga um trabalho em curva descendente. Sua biblioteca tem acompanhado essa tendência ? Há dados do setor de referência que corroboram essa interferência na pesquisa científica ?

Até o momento, não claramente. É fato que a literatura disponível eletronicamente e portanto mais recente, tem tendência a ser mais utilizada, porém na área de pesquisa não há como abandonar as pesquisas anteriores. Há que se verificar o fato dos editores estarem constantemente ampliando o acesso ao texto completo de seus periódicos para periódicos cada vez mais antigos, no sentido de terem ao final de um prazo, todo o material disponível.

7. São do seu conhecimento estatísticas que comprovem um crescimento do uso das coleções eletrônicas nos últimos 6 (seis) meses feita pelo consórcio ? Se sim, como é feita a coleta de dados?

Sim. A coleta de dados é feita através de estatísticas de acesso, que para cada editor, portal, é colhida de maneira específica, porém sempre controlada por IP.

8. O autor Edward Shreeves expõe que "... nos últimos anos, houve um crescimento acelerado do volume e diversidade de formatos de documentos disponíveis, tornando o gerenciamento de coleções uma atividade cada vez mais complexa, onde grande parte das bibliotecas - e aí incluímos as maiores - ainda não possuem ferramentas ou mecanismos eficazes para administrar suas coleções e oferecer mais informação (grifo meu) aos usuários, que as solicitam num prazo cada vez menor". A sua experiência confirma esta afirmação ? Justifique. 
É fato que o gerenciamento das coleções tem se tornado tarefa cada vez mais difícil. Temos, a meu ver, dois pesos a serem considerados:

- é ainda grande a resistência dos pesquisadores ao texto eletrônico. Temos grupos que têm dificuldade de absorver novas tecnologias;

- apesar disto, mesmo os pesquisadores com dificuldades na absorção destas novas tecnologias, não podem se privar dela.

Cabe à biblioteca, além de gerenciar suas coleções de forma a dar atendimento adequado a todos os segmentos, fazer a ponte entre estas duas partes.

9. O empréstimo interbibliotecário e o envio de documentos (document delivery) aumentou ou diminuiu com a inserção dos periódicos eletrônicos, em especial com o acesso oferecido pelo ProBE ? Você acha que os consórcios em geral reforçam o atendimento sob demanda ? O pagamento deste serviço deveria ser subsidiado pela instituição ou órgão de fomento ou até mesmo ser custeado pelo próprio pesquisador ?

Houve redução no empréstimo de periódicos. Acredito que este serviço possa ser subsidiado pela instituição ou órgão de fomento, quer seja de maneira direta, como é o caso do Portal de Periódicos da CAPES e ProBE, ou de maneira indireta, através da utilização de "reserva técnica" de suas pesquisas para o acesso a periódicos eletrônicos.

10. Quantos bibliotecários em sua instituição trabalham diretamente com o gerenciamento de coleções de periódicos científicos ?

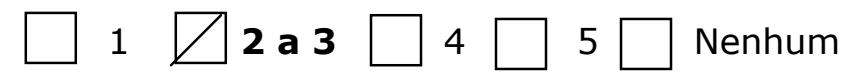

11. (Se sua resposta à questão anterior for Nenhum, passe para a questão seguinte). Desses profissionais, quantos possuem o domínio de ferramentas para trabalhar com a Internet (algum editor HTML - como DreamWeaver, Front Page, etc. - FTP) ?
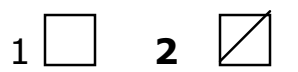

3

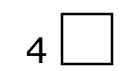

5 ou mais

12. Como sua biblioteca cobra pelos serviços relacionados ao uso de periódicos científicos ? Informe sobre cada um dos serviços existentes, conforme indicado a seguir:

a) Xerox

$\square$ Não oferecido $\square$ Pago $\square$ Gratuito 
b) Empréstimo interbibliotecário
$\square$ Não oferecido $\square$ Pago $\square$ Gratuito
c) Envio de documentos ou Document delivery (Ariel, etc.)

$\square$ Não oferecido $\square$ Pago $\square$ Gratuito

d) Download de artigos

$\square$ Não oferecido $\square$ Pago $\square$ Gratuito

e) Empréstimo domiciliar

$\square$ Não oferecido $\square$ Pago $\square$ Gratuito

f) Pesquisa em bases de dados

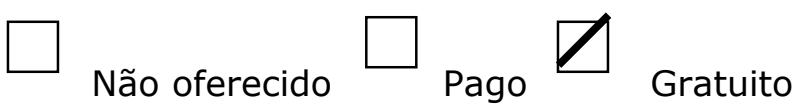

13. Quais são, em seu ponto de vista, as outras iniciativas nacionais na América Latina que merecem destaque enquanto projetos de democratização do acesso à informação, tratando-se de consórcios?

Consórcio CRUESP - acesso a bases de dados; SCIELO.

14. A política de seleção de publicações feita por consórcios está restrita a um determinado tipo de publicação: a informação científica e altamente especializada, cujo mercado trata tal informação sobretudo como um bem mercantil, dado o alto custo de suas assinaturas. Um consórcio de bibliotecas brasileiras não poderia contemplar outro tipo de publicação ? Se sim, qual tipo e porquê ?

Acho que uma possibilidade seria um consórcio de Bibliotecas Públicas, para atendimento da população em geral, tão carente de recursos para sua formação, informação e aperfeiçoamento. Poderíamos ter um compartilhamento de acervos "eletrônicos", minimizando desta forma as diferenças entre os vários estados. Assim, a Biblioteca pública, além de seu acervo, deveria disponibilizar o acesso a esta informação, através de equipamentos que ficariam a disposição da população. 


\section{Respostas modelo II : Agente distribuidor de periódicos científicos do mercado brasileiro}

1. É inegável que a globalização de mercados e a migração das publicações científicas para o universo eletrônico fez com que a maioria dos grandes agentes distribuidores realinhassem suas políticas de vendas em todo o mundo, América Latina inclusive. Como o senhor tem observado o comportamento dos preços das publicações nos últimos anos e qual a interferência destes nessas políticas?

R. acredito que os editores tem buscado criar fontes de comercialização de seus produtos eletrônicos diretamente com clientes existentes no mercado internacional. A disponibilização do acesso eletrônico tem contribuído para a manutenção da média anual de preços que chega a $10,12 \%$, em sua grande maioria. No entanto, temos observado o acréscimo acima da média anual, chegando alguns casos a $50 \%$ de aumento ou mais. Os editores sabem que a versão eletrônica os manterão consistentes no mercado e por isso visam acrescentar a viabilização de tais títulos na Internet.

2. Qual é o total estimado de periódicos eletrônicos oferecidos para o mercado brasileiro atualmente, após a globalização ? Há previsões de crescimento da oferta atual ?

R. o editor não distingue ainda o mercado brasileiro dos demais. Na verdade, quando um título eletrônico está disponível, todos os usuários podem obter o direito de aceso a esses títulos. Cremos que $10 \%$ das publicações disponíveis no mercado internacional já se encontram disponíveis na web.

3. Ao participar diretamente do consórcio ProBE como uma das empresas escolhidas para fornecer um grande leque de publicações periódicas científicas, indiretamente estão contribuindo para o processo de democratização da informação nas Universidades. Como o senhor analisa esta nova realidade?

R. acreditamos que a democratização e disponibilidade de produções científicas devem estar disponíveis a um leque ilimitado de pesquisadores e nos sentimos orgulhosos por termos sido escolhidos para participar de um projeto inovador e autêntico na America Latina. Esta realidade é algo que todos teremos de nos adaptar, inclusive os editores que estarão sendo obrigados a aceitar tais negociações para manterem-se firmes no mercado internacional. 
4. Em relação ao mercado global de periódicos científicos, nos últimos tempos temos assistido a uma série de fusões e compras entre grandes empresas fornecedoras de periódicos. No caso específico da América Latina, qual a sua opinião sobre este mercado para os próximos anos ? Qual é a estratégia de ação de sua empresa?

R. nossa empresa é uma empresa sólida com existência de mais de 50 anos no mercado de assinaturas internacionais e não pretendemos nos fundir com outra empresa no mercado. Vemos as fusões de assinaturas por grandes empresas como resultado de uma tentativa de reação a competitividade no mercado. Cremos que as fusões podem ser negativas do ponto de vista de competitividade, restando poucas alternativas para os clientes a escolha com quem trabalhar. Fusões geram compromissos financeiros que, consequentemente, devem ser observadas com muita cautela durante o processo de assinatura.

5. As bibliotecas têm incrementado seus programas de marketing e divulgação visando aumentar o uso de periódicos eletrônicos, sobretudo daqueles considerados os mais importantes. O senhor acha, de um modo geral, eficazes tais programas de recuperação ?

R. sim. É importante que as bibliotecas tenham o compromisso de divulgação das ferramentas e material disponível para seus usuários. A atualização de tal material e conforto para seu uso pode trazer benefícios fundamentais durante um processo de pesquisa.

6. Recentemente, todos os grandes agentes distribuidores promoveram significativas mudanças em suas interfaces de busca e consulta, chegando mesmo alguns estudiosos a afirmar que estas já suplantam em muito as existentes nas próprias bibliotecas. Serão feitos investimentos e novos desenvolvimentos para esta área nos próximos anos por sua companhia?

R. EBSCO está constantemente investindo em novas tecnologias tendo como principal objetivo a satisfação de nossos clientes. Acreditamos que com novas atualizações de ferramentas já disponíveis comprova nosso compromisso de tornar disponível uma solução única para a busca de material científico. Novos investimentos continuarão existindo para alcançarmos um ponto de excelência máxima de satisfação de nossos clientes.

7. Qual a sua opinião sobre a mudança do impresso para uma cultura digital nos meios acadêmico e científico ? O uso dos periódicos eletrônicos tenderá a substituir o próprio uso das coleções impressas? 
R. acredito que a mudança é irreversível e tende a se consolidar no prazo de 10 anos. Não acredito na substituição plena das coleções eletrônicas por coleções impressas devido ao controle de aquisição imposto pelos editores que terão de ceder a esta realidade. A realidade brasileira exige ainda mais cultivo de utilização de tal material e maior aceitação desta informação de forma eletrônica.

8. A política de seleção de publicações feita pelo consórcio está restrita a um determinado tipo de publicação: a informação científica e altamente especializada, cujo mercado trata tal informação sobretudo como um bem mercantil, dado o relativo alto custo de suas assinaturas. A seu ver, sua empresa teria condições de oferecer produtos de outro tipo para o consórcio, com um custo significativamente mais baixo ? Se sim, quais seriam as características desse e as condições para seu lançamento ?

R. o custo dos consórcios eletrônicos está $100 \%$ atrelado ao editor, que possui os direitos autorais de comercialização dos periódicos científicos. A única alternativa para uma redução de custo seria a junção de uma maior quantidade de títulos consorciados pelos interessados para que seja forçado junto aos editores melhores condições de preço. 


\section{Respostas da entrevista junto à Coordenadoria Operacional e Gerência do Consórcio}

\section{Como você vê a relação entre a globalização, a migração dos periódicos para o digital,}

na América Latina?

Eu vejo como uma necessidade social, econômica, pois nós sabemos desse crescimento exponencial da informação, dessa valorização da informação somada ao aumento dos custos e a questão de que as instituições estão com cada vez menores orçamentos para estarem adquirindo esta informação. Então esses três aspectos da globalização exigem o trabalho compartilhado, conjunto e distribuído, certo, para que se consiga acessar estas informações necessárias para todos. Então, isso levou ao trabalho do consórcio, aonde cada um paga uma parcela e todos ganham a totalidade das informações que existem no consórcio. Então, é a forma de se fazer uma racionalização na compra e um benefício muito grande para o profissional - pesquisador na área acadêmica.

E é uma conseqüência do mundo, onde se vê na Europa a constituição da nova moeda. É nesse linha que o consórcio deu certo. É uma experiência inédita aqui, nossa, tentamos criar essa coisa e é a expectativa de todo mundo (ação compartilhada).

\section{Como podemos distinguir a evolução do ProBE ? Em duas fases bem distintas ? Está correta esta divisória de águas ?}

As pessoas não tinham uma percepção das vantagens de um consórcio, incluindo as bibliotecárias e os próprios dirigentes dessas instituições. Eu sempre via a dificuldade das pessoas trabalhar cooperativamente. Havia uma cultura "do que é meu" (cultura da posse), de olhar o próprio umbigo. E pelo próprio temor das bibliotecas de que vamos nos tornar algo a mais, um elemento externo estranho. A criação foi com o Aloísio Mercadante (UNICAMP), a BIREME, comigo na USP, as experiências do COMUT. O consórcio passou a ser solicitado pelas bibliotecas menores, pois saberiam que iriam pagar menos e ganhar muito, então para essas bibliotecas se tornou extremamente forte, saudável. A cooperação uniu as instituições, incluindo suas instâncias jurídicas. $E$ agora também há o interesse dos institutos de pesquisa. $E$ a FAPESP foi fundamental com seu aporte de recursos. E há uma consciência no Brasil hoje em dia de que é esse o caminho, e foi por aí que entrou a CAPES, que está procurando copiar o nosso modelo. Então, há dois principais momentos distintos: o de criação e fomento dessa cultura (do digital) e o da ampliação desse pequeno modelo do eletrônico (cultura do uso). Como exemplo, foi a primeira vez que se reuniu os institutos na área da saúde conscientes de seu poder cooperativo. 


\section{O ProBE vai passar a ser gerenciado pela CAPES ? Vocês poderão continuar a fazer os}

estudos de coleções cooperativos necessários ?

O termo de consórcio termina agora em março de 2002. Então, na realidade, a CAPES vai subsididar essas instituições "guarda-chuva" (USP, UNESP, UNICAMP, UFSCAR, UNIFESP) e uma outra instituição. Pretendemos criar então um termo de cooperação onde essas instituições que estarão na CAPES e mantêm o programa ProBE como cooperante para estudos de subsídio da CAPES e que possa também estar assinando bases de dados e títulos que a CAPES não vai cobrir. A FAPESP está se propondo a subsidiar os institutos de pesquisas coitados que não vão nem para a CAPES e não teriam como estar aqui sozinhos -, e nós estamos convidando para substituir esse valor alto das instituições 'guarda-chuva', algumas instituições particulares, que poderiam fazer a correspondência de títulos assinados que seriam a contrapartida.

Se esse modelo der certo nós passaremos novamente para um consórcio, mas por enquanto vai ficar como "cooperação institucional". Há vários apelos das instituições particulares para entrarem no ProBE e há o fator de entrarem para o MEC. Então, usaríamos o interesse político dessas instituições em atingir o nível cinco de seus cursos de pós-graduação e terem seus cursos aprovados.

4. Entre as ferramentas de avaliação de periódicos, quais você considera as mais importantes ? E o JCR, continuará a ser utilizado ?

Acho que sim. Ele é um dos elementos fortes, a demanda de uso do impresso, a avaliação do uso online (iniciando-se), as estatísticas de uso dos periódicos. Eles definem o que vamos ou não comprarmos. De 1998 para 1999 houve um aumento muito acentuado do dólar e uma queda de orçamentos para compra, o que fez com que USP, UNICAMP, UNIFESP e UNESP fizessem uma reavaliação de seus acervos, estabelecendo títulos prioritários, menos prioritários, etc.

\section{Como você vê a divisão do mercado de periódicos científicos aqui no Brasil ? Existe uma empresa que domine esse mercado?}

Bom, há tendência é a Thompsom. Ela tem o ISI (Web of Science), e comprou a Elsevier. Não sabemos ao certo o quanto ela domina este mercado. A Academic Press está sendo assumida pela Elsevier; há um trabalho de merging entre a Swets e a Blackwell. Na Europa (especificamente na Holanda), houve uma tentativa da Kluwer de se juntar com a Elsevier mas lá não conseguiram por pressão da comunidade. Por lei, eles têm que informar a comunidade, 
através de Diário Oficial, e as pessoas e instituições (sociedade) fazem suas manifestações favoráveis ou não.

\section{6. ... e no caso brasileiro, foi algo publicado aqui ?}

Não, é publicado oficialmente em âmbito internacional. Ou seja, há uma incoerência com o nosso direito de expressar a concordância com a formação de determinado grupo ou até cartel. Eles buscam assim se defender da proposta do 'Open Archives', por exemplo, da área de física, na qual a comunidade científica busca "fugir" do editor comercial, tendo um trabalho idêntico na própria academia - incluindo o comitê editorial etc. - mas, por outro lado, eles - os pesquisadores - buscam publicar em revistas de alto fator de impacto que continuarão a exercer forte influência na literatura científica. Estas associações profissionais tendem assim a tornar os artigos gratuitos, e não comercializá-los (numa pressão contrária, sadia a equidade do conhecimento - grifo meu).

O editor comercial, por sua vez, está criando fatores agregados muito importantes. Por exemplo, o "cross reference", com links de uma lista de referências de uma editora para outra, de uma revista para outra. Isto é uma facilidade de navegação para o pesquisador, é importante para ele, é uma ferramenta rápida, o que por sua vez o 'Open Archives' (ainda, grifo meu) enquanto projeto não consegue realizar.

O 'Open Archives' não consegue fazer toda esta tramitação, e para isto o editor necessita ter um gerente dedicado. E na área acadêmica, fazer isto, é difícil, pois o fato de um pesquisador ou professor ser editor de uma revista (gerente) não tem valor nenhum para a área acadêmica... Isto se torna então um sacrifício, que acaba nem constando no seu currículo como algo importante. A ABEC - Associação Brasileira de Editores Científicos - está fazendo um trabalho para que as instituições valorizem isso como um elemento da sua profissão científica, de modo que ele possa - e seja motivado - a se dedicar um pouco mais. Tudo isso se deve pesar então para sabermos o que de fato vai permanecer. Temos um momento híbrido aí de transição.

\section{7. ... então você acha que os oligopólios - ao menos agora - estão cada vez mais fortes ?}

Sim, por causa desses valores agregados que as grandes empresas fornecedoras oferecem (o 'cross-reference', a seleção de revistas com um alto fator de impacto atestado pelo ISI para a área acadêmica, o que é um elemento excepcional no contexto atual (casos da Wolters Kluwer, Academic Press, High Wire, Elsevier, Swets-Blackwell. (e, principalmente então, Thompson grifo meu). 


\section{Você destaca outros consórcios importantes de revistas científicas na América Latina ?}

Estão havendo tentativas nesses últimos tempos. Na Venezuela, há um consórcio na áea de ciências agrárias; na Argentina, eu estive agora lá e existe uma proposta de uma fundação na área de educação para articular universidades em torno de um consórcio, em Mendonza, na área de ciências agrárias, para as instituições formarem um consórcio; no Chile existe uma proposta do CONSIST liderada por uma pessoa, a Sra. Ana Maria Prates - que trabalha para o Scielo / Chile, tentando abrir um consórcio; e ainda existe um outro consórcio, mas é pago e gerenciado de forma diferente: no caso; há uma gerente paga pelas editoras que faz um trabalho de agregador - ela reúne, distribui, etc. os títulos - e deve haver também um lucro também por parte das instituições envolvidas. E no último Congresso em Cuba (o CRICS IV), discutimos a questão de viabilizar a intenção de formação de um consórcio das bibliotecas cooperantes da Rede BIREME; no México há outro consórcio, através da UNAM, mas é interessante que é um consórcio "local", ou melhor, entre as faculdades dessa universidade apenas. E há um trabalho no Rio de Janeiro, o projeto COMPARTILHAR, onde já há o compartilhamento de permutas e empréstimos e o grupo de bibliotecárias começou a discutir o compartilhamento de aquisições (incluindo bases de dados).

O que eu sinto é que as pessoas querem começar a fazê-lo (um consórcio) mas não sabem bem como fazê-lo. Lembro-me que quando começamos o ProBE, não havia modelo nenhum, mas nós já tínhamos uma visão e experiência de custos, uma cultura para compras, de modo que quando os fornecedores vieram para as primeiras negociações - e a gerente cita particularmente os da Elsevier - e não tinham noção nenhuma dos valores aqui praticados e queriam cobrar valores altíssimos, totalmente for a de nossa realidade.

\section{Qual é a taxa de juros, então, no caso, cobrada sobre o preço dos periódicos eletrônicos em relação aos impressos ?}

É de $15 \%$ (quinze por cento), e se mantém. A negociação começou com 17\% (dezessete por cento) e fechamos com a taxa atual. Quando se assinava o impresso, de um ano para outro o preço se inflacionava $12 \%$ (doze por cento) e hoje estamos com $6 \%$ (seis por cento) somente. $\mathrm{E}$ por que isso ? Pois somos um grupo muito grande instituições que, através do consórcio, força a queda desses preços (não há aí uma contrapartida de ganhos por parte do grande editor comercial ? grifo meu)

10. Como você analisa as políticas nacionais de informação ? Elas têm ajudado o ProBE ou não?

Eu acho que tivemos sensibilidade boa a nível de instituições, mas do governo do Estado, não tivemos a mesma sensibilidade, porque não chegamos lá, talvez. Mas, por outro lado, do MEC - 
através da CAPES - já houve uma sensibilidade no sentido de aplicar o programa nas universidades. E da própria Sociedade da Informação não houve um reconhecimento e um estímulo e acho que porque eles se colocam numa esfera mais alta, discutindo questões de "maior relevância". Pelo menos nós não percebemos nada, o estímulo veio de baixo para cima, à exceção do MEC, e não o contrário. E aliás, o MEC começou este apoio desde os tempos do PAP (Programa de Aquisição Planificada), nos anos de 1975, aproximadamente. Houve um grande impacto deste em 1988, onde foram feitos diversos estudos. Antes disso então, iniciativas nacionais para compra de periódicos eram muito pequenas, e praticamente inexistiram e não foram representativas.

\section{Você acha que um consórcio não poderia contemplar um outro tipo de publicação ? \\ Por exemplo, você não acha que poderia expandir essas iniciativas para bibliotecas públicas, como uma forma de democratização ?}

Eu acho que sim, mas há aí um problema sério: as bibliotecas públicas sempre dependem do Estado, isto é, não há contrapartidas das próprias instituições, não vejo nelas uma motivação (será que de fato não existiria ? - grifo meu), como aliando as do estado de Minas Gerais, usando-se da FAPEMIG. Por exemplo, nos Estados Unidos, ao contrário, há diversas iniciativas como a do CICS. Não há, então, iniciativa própria, genericamente, dessas bibliotecas. A exceção são as do Rio de Janeiro que já estão se articulando nesse sentido.

Outro caso digno de destaque é a da Biblioteca Nacional, que vem propondo atividades cooperativas, o que nada mais é do que parte de sua missão, dando treinamento, etc. É este o motivo pelo próprio projeto BIBLIODATA CALCO não ter ido para frente: ele nasceu e não vingou pois surgiu em uma instituição particular e não pública, isto é, visa antes de mais nada o lucro. E o BIBLIODATA CALCO foi um projeto pioneiro, paradoxalmente.

\section{Quais as dificuldades e limitações atuais da comunidade de usuários para uso das coleções do ProBE ?}

Acho que falta um marketing maior, de disseminação dos recursos existentes maior, e tinha que estar mais ativo nas instituições, dando treinamento etc., talvez porque haja um receio de que elas vão perder os seus usuários, mas isso é um ponto de interrogação para nós. Nós, a nível gerencial, fazemos todo um trabalho de divulgação e multiplicação e esperamos que os bibliotecários repassem isso tudo. $\mathrm{E}$ há dois segmentos específicos que trabalham diretamente com isso: bibliotecários de aquisição e bibliotecários de referência. É a transição da cultura da posse para a cultura do acesso. E também parece falta haver esse trabalho nos próprios cursos de graduação, mostrando que as bibliotecas mudaram seus conceitos e modos de atuação. 
13. ... e a questão do acesso controlado pelo IP, a médio e longo prazos, para o ProBE ? Essa é uma questão muito difícil, pois se abríssemos a senha para mais de 200.000 pesquisadores - usuários do ProBE - criaria-se uma crise no programa pela divulgação irrestrita e para além de seus limites. E só funciona para o caso de um público muito pequeno, onde isso possa ser controlado.

Entrevista concedida em Dezembro de 2001, em São Paulo. 